\title{
PILOT STUDY RISK ASSESSMENT \\ FOR SELECTED PROBLEMS AT THE SAVANNAH RIVER SITE (SRS)
}

L. D. Hamilton, S. Holtzman, A. Meinhold, S. C. Morris, R. Pardi, C. Sun, J. I. Daniels, ${ }^{*}$ D. Layton, ${ }^{*}$ T. E. McKone, ${ }^{*}$ and T. Straume*

*Health and Ecological Assessment Division Geosciences and Environmental Research Program Physics Department

Lawrence Livermore National Laboratory

Livermore, CA 94551-9900

March 1993

Prepared for Office of Environmental Restoration and Waste Management

Office of Technology Development

\section{BIOMEDICAL AND ENVIRONMENTAL ASSESSMENT GROUP}

ANALYTICAL SCIENCES DIVISION DEPARTMENT OF APPLIED SCIENCE BROOKHAVEN NATIONAL LABORATORY ASSOCIATED UNIVERSITIES, INC.

Under Contract No. DE-AC02-76CH00016 with the U. S. Department of Energy 


\section{DISCLAIMER}

This report was prepared as an account of work sponsored by an agency of the United States Government. Neither the United States Government nor any agency thereof, nor any of their employees, not any of their contractors, subcontractors, or their employees, makes any warranty, express or implied, or assumes any legal liability or responsibility for the accuracy, completeness, or usefulness of any information, apparatus, product, or process disclosed, or represents that its use would not infringe privately owned rights. Reference herein to any specific commercial product, process, or service by trade name, trademark, manufacturer, or otherwise, does not necessarily constitute or imply its endorsement, recommendation, or favoring by the United States Government or any agency, contractor, or subcontractor thereof. The views and opinions of authors expressed herein do not necessarily state or reflect those of the United States Government or any agency, contractor or subcontractor thereof. 


\section{ACKNOWLEDGMENTS}

This study was funded by the United States Department of Energy, Office of Environmental Restoration and Waste Management, Office of Technology Development. The Project Officer for the effort was Mr. Michael Barainca. This pilot study was a collaborative effort between Brookhaven National Laboratory (BNL) and Lawrence Livermore National Laboratory (LLNL). The principal investigator for the BNL effort was Dr. L.D. Hamilton. The principal investigators for the LLNL work were Dr. L. Anspaugh and Dr. D. Layton. We thank the staff of the Westinghouse Savannah River Company and USDOE personnel associated with the Savannah River Site for their cooperation, and Mr. Leo Duffy and Dr. Clyde Frank for their encouragement and support. 


\section{ABSTRACT}

An assessment of the health risks was made for releases of tritium and ${ }^{137} \mathrm{Cs}$ from the Savannah River Site (SRS) at water-receptor locations downriver. Although reactor operations were shut down at the SRS in 1989, liquid wastes continue to be released to the Savannah River either by direct discharges into onsite surface waters or by groundwater transport into surface waters from waste facilities. Existing state mandates will cause the liquid waste streams from future operations to go directly into surface waters. Two drinking water processing plants take water from the river approximately $129 \mathrm{~km}$ downriver from the SRS. The domestic populations supplied by these facilities are expected to increase from 57,000 , in 1990 , to 367,000 , by the year 2000 . Potential incremental risks of cancer fatality to individuals and each population were analyzed for either no further reactor operations or resumption of operation of one specific reactor.

The major radioactive component of the releases (approximatel. 99\%) is tritium. On the basis of data back to 1954, an empirical model was developed to predict annual releases of tritium to the Savannah River, and tritium concentrations in the water at the receptor locations. Groundwater migration from previous releases to waste facilities is expected to be a component of the source terms until the year 2004. The major exposure pathways for the receptor populations are ingestion of tap water $(85 \%)$, and inhalation of water vapor wnile bathing in the home (15\%). Exposures from other pathways are lower by at least one order of magnitude. For the year of maximal exposure, the $95 \%$ cumulative level of incremental risk of cancer death is $8 \times 1^{10^{-7}}$. No deaths are expected in either receptor population as a result of exposures to tritium released to the Savannah River.

Less than $600 \mathrm{Ci}$ of ${ }^{137} \mathrm{Cs}$ has been released to onsite streams from SRS operations since 1954, most of which has bound to sediments of the stream beds of the onsite tributaries. Less than half this amount remains because of the combined effects of radioactive decay, solution and suspension discharge to the Savannah River. The estimated rate of discharge to the river, less than $0.5 \mathrm{Ci}$ per year, is expected to be maintained into the first quarter of the twenty-second century, in the presence or absence of further operations at the SRS. The major exposure pathways for the receptor populations described above are ingestion of finfish taken from the river, and ingestion of tap water. Exposure from fish ingestion averages 9 to 18 times greater than from drinking water, because of bioconcentration in fish and removal of $137 \mathrm{Cs}$ by the water purification plants. The $95 \%$ cumulative level of incremental risk of cancer death is less than $10^{-8}$. No deaths are expected in either receptor population as a result of exposures to ${ }^{137} \mathrm{Cs}$ released to the Savannah River.

These assessments employed realistic distributions of parameter values in place of conservative default values to yield probabilistic predictions of risk and their associated uncertainties. 


\section{Table of Contents}

ACKNOWLEDGMENTS .................................................................. i

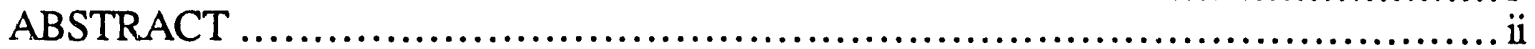

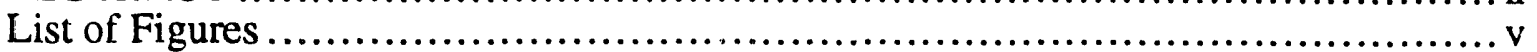

List of Tables ........................................................................... vi

Glossary of Abbreviations, Acronyms and Symbols ..................................... vii

Units of radionuclide activity ........................................................ ix

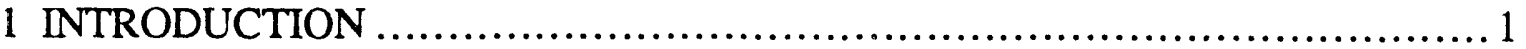

2 RISK ASSESSMENTS FOR U.S. DEPARTMENT OF ENERGY SITES............ 2

$2.1 \quad$ Risk Assessment................................................................ 2

2.2 Approaches to Risk Assessment................................................... 3

2.3 Pilot Study Approach to Realistic Risk Assessment for USDOE Facilities........... 6

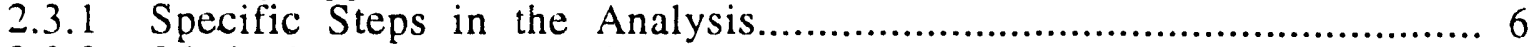

2.3.2 Methods and Assumptions....................................................... 8

3 OVERVIEW OF THE SAVANNAH RIVER SITE ....................................... 11

3.1 Regional Setting and Physical Environment.......................................... 11

3.1.1 Location ...................................................................... 11

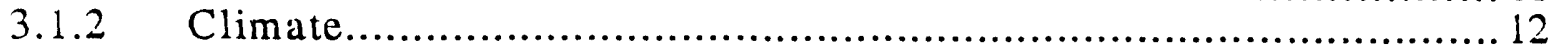

3.1.3 Hydrology .................................................................. 12

3.1.4 Physiography and Hydrogeology ............................................ 13

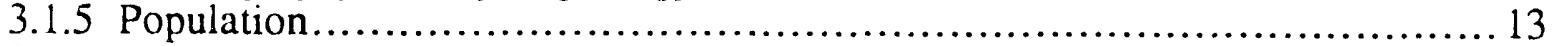

3.1.6 Land Use ........................................................................ 13

3.1.7 Use of Surface and Ground Water................................................... 15

3.2 Site Description and Site Operations ........................................... 15

3.3 Environmental Concerns......................................................... 16

3.4 Environmental Monitoring and Site Restoration ................................ 17

3.4.1 Environmental Monitoring Program ..................................... 17

4 PROBLEMS TO BE STUDIED IN RISK ASSESSMENT ........................ 18

4.1 Criteria for Problem Selection....................................................... 18

4.2 Problem 1: Tritium Release to the Savannah River ................................. 18

4.3 Problem 2: Cesium ( $\left.{ }^{137} \mathrm{Cs}\right)$ Contamination in the Savannah River ................. 19

4.4 Problems Identified for Future Assessments ................................... 20

5 HUMAN HEALTH RISK ASSESSMENT FOR TRITIUM RELEASED TO THE

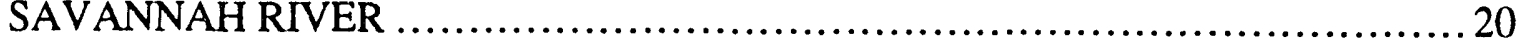

5.1 Major Steps in the Risk Assessment for Tritium .............................. 20

5.2 Problem Summary .................................................................. 20

5.3 The Sources of Tritium at the SRS ................................................... 21

5.3.1 Direct and Indirect Discharges................................................ 21

5.3.2 Current Status ............................................................. 21

5.3.3 Scenarios and Empirical Models............................................................ 22

5.3.4 Source Term Development ......................................................... 22

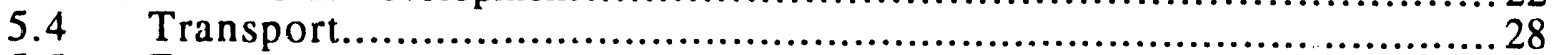

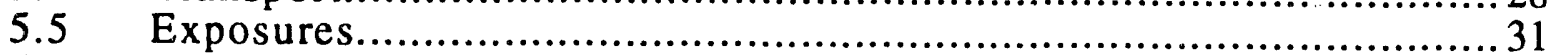

5.5.1 Exposure Pathways ......................................................................... 31

5.6 Conversion of Tritiated Water Exposure to Dose ......................................... 35

5.7 Risk Characterization-Cancer Mortality ................................................... 36

5.7.1 Incremental Individual Risks (IR) for cancer death ................................... 37

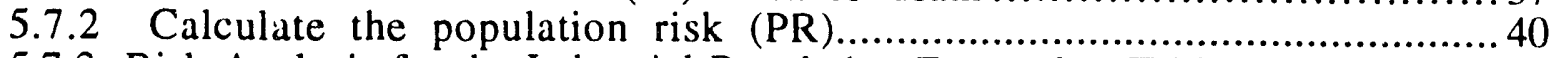

5.7.3 Risk Analysis for the Industrial Population Exposed to Tritium........................ 41 
6 HUMAN HEALTH RISK ASSESSMENT FOR ${ }^{137}$ Cs .......................... 45

6.1 Major Steps in the Risk Assessment for ${ }^{137}$ Cs...................................45

6.2 Problem Summary ...................................................... 46

6.3 The Sources of ${ }^{137} \mathrm{Cs}$ at the SRS ........................................... 46

6.3.1 Water Discharges from SRS Operations to Streams ......................... 47

6.3.2 Role of Cesium Chemistry ............................................... 47

$6.3 .3{ }^{137} \mathrm{Cs}$ Delivery to the Savannah River..................................... 48

6.4 Transport of ${ }^{137} \mathrm{Cs}$ in the Savannah River..................................... 50

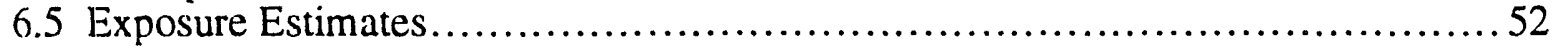

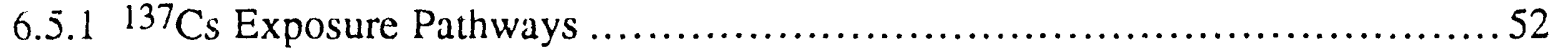

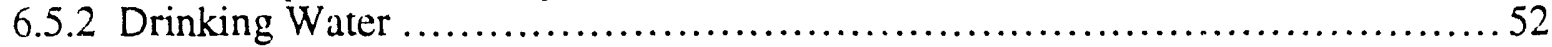

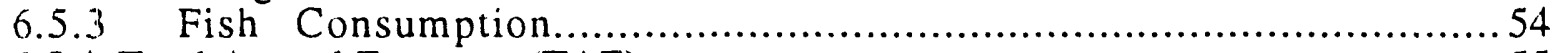

6.5.4 Total Annual Exposure (TAE) ............................................ 55

6.6 Risk Characterization: Cancer Mortality ................................... 55

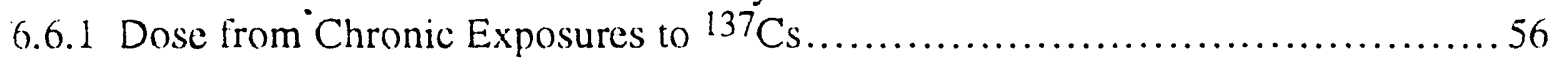

6.6.2 Incremental Individual Risk (IR) lor Cancer Mortality ....................... 56

6.6.3 The Population Risk (PR) for a Receptor Population......................... 57

6.6.4 Cesium in SRS Streams .................................................... 57

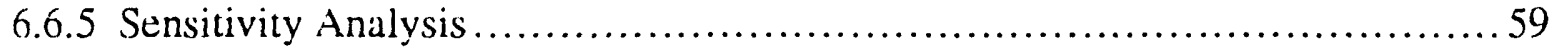

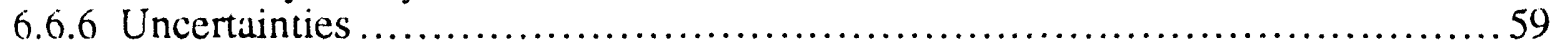

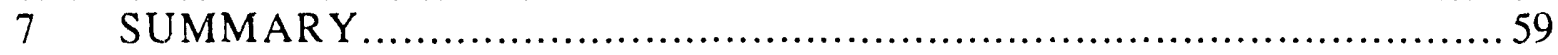

References........................................................... 61

APPENDIX 1 -- GROUND WATER CONTAMINATION IN THE A\&M AREA ..... 65 


\section{List of Figures}

2.1 Spectrum of Approaches to Risk Assessment....................................... 5

2.2. Steps in the Assessment..................................................... 7

2.3 Probabilistic Risk Assessment Example............................................. 10

3.1 The Savannah River Site.......................................................... 11

3.2 Locations of Major Water Treatment Plants Using Savannah River Water....... 14

5.1a Relationship of Total Releases of Tritium (1980-1989) to the Predicted Tritium

Discharges to Surface Waters During the Next Ten Year Period (1990-1999).... 25

5.1b Linear Model for Predicting Tritium Releases from Seepage to Surface Waters.. 26

5.2 Comparison of Frequency Distributions for Incremental Risks from Estimated

1993 Tritium Concentrations in Savannah River Drinking Water to the

Distributions Estimated for the USEPA Standard for Drinking Water............. 40

6.1 The Savannah River Site...................................................... 45

6.4 Average Concentrations of ${ }^{137} \mathrm{Cs}$ in Water Along the Savannah River........... 50

A.1 Western Portion of the Savannah River Site; showing the Location of the A and

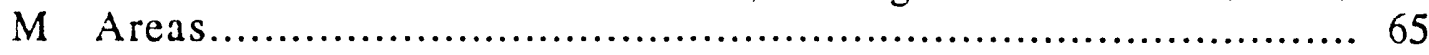




\section{List of Tables}

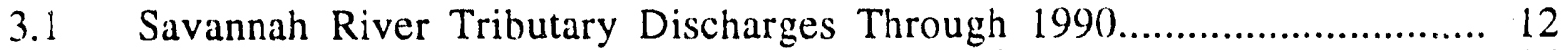

3.2 Operating Status for SRS Facilities During 1989............................. 16

3.3 Types of Samples Analyzed in the Radiological Monitoring Program............ 17

3.4 Samples Analyzed in the Nonradiological Program.............................. 18

5.1 Annual Tritium Releases To Surface Waters at the SRS....................... 23

5.2 Predicted Annual Migration from Ground Water to Surface Waters at the SRS.. 24

5.3 Predicted Discharges to Surface Waters from Past and Future Releases to Groundwater and Directly from Future Operations........................... 27

5.4 Predicted Discharges to Surface Waters from Past Releases to Groundwater and from Future Operational Releases to Surface Waters Only....................... 27

5.5 Annual Averages of Measured Concentrations of Tritium in the Savannah River. 29

5.6 Predicted Average Concentrations of Tritium in the Savannah River.............. 29

5.7 Factors for Calculating Exposures to Tritium in Water Taken from the Savannah River................................................................ 30

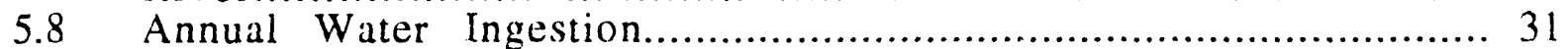

5.9 Annual Finfish Ingestion................................................. 32

5.10 Total Annual Exposures to Tritium in the Beautort-Jasper and Port Wentworth Water Supplies.......................................................... 35

5.11 Annual Absorbed Doses Resulting from Exposures to Tritium in the Beaufort-Jasper and port Wentworth Water Supplies............................ 36

5.12 Incremental Individual Lifetime Mortality Risks from Annual Exposures to Tritium in the Beaufort-Jasper and Port Wentworth Water Supplies.............. 38

5.13 Comparison of Statistics for the Predicted 1993 Receptor Concentrations of of Tritium to Statistics for the Current USEPA Drinking Water Standard........ 39

5.14 Incremental Number of Cancer Deaths Resulting from Annual Exposures of Populations to Tritium in the Beaufort-Jasper Water Supply....................... 40

5.15 Incremental Number of Cancer Deaths Resulting from Annual Exposures of Populations to Tritium in the Port Wentworth Water Supply....................... 41

5.16 Results of Sensitivity Analysis for Major Parameters in Overall Uncertainties of Individual Risk........................................................ 43

5.17 Influence of a 4)\% in Release on Statistics for Predicted 1993 Receptor Concentrations of Tritium with Comparisons to the USEPA Drinking Water Standard............................................................... 44

5.18 Influence of Greater Rates of Water Ingestion on Statistics Por Predicted 1993 Receptor Concentrations of Tritium...................................... 44

6.1 Average Annual Measured Concentrations of ${ }^{137} \mathrm{Cs}$ in the Savannah River and Calculated Annual Releases from the SRS..................................... 48

6.2 Annual Flow in the Savannah River............................................ 49

6.3 Annual Arithmetic Average Concentrations of ${ }^{137} \mathrm{Cs}$ in Sediments Along the Savannah River........................................................ 51

6.4 Derivation of Dilution Factors from Measurement Averages of [ ${ }^{137} \mathrm{Cs}$ ] for Raw Water at the Beaufort-Jasper and Port Wentworth Water Purification Facilities... 51

6.5 Predicted Raw Water [ ${ }^{137} \mathrm{Cs}$ ] at the Beaufort-Jasper and Port Wentworth Water Purification Facilities..................................................... 52

6.6 Derivation of Removal Factors from Measurement Averages of [ [ ${ }^{137} \mathrm{Cs}$ ], for Drinking Water at the Beaufort-Jasper and Port Wentworth Facilities..

6.7 Predicted Finished Water [ $\left.{ }^{137} \mathrm{Cs}\right]$ at the Beaufort-Jasper and Port Wentworth Water Purification Facilities................................................. 53 
6.8 Predicted Annual Intakes of ${ }^{137} \mathrm{Cs}$ in Drinking Water from the Beaufort-Jasper and Port Wentworth Water Processing Plants.......................................... 53

6.9 Bioconcentration Factors for ${ }^{137} \mathrm{Cs}$ in Whole Fish Taken from the Savannah River, Above and Below the Savannah River Site.

6.10 Predicted Annual Exposures to ${ }^{137} \mathrm{Cs}$ by Ingestion of Finfish from the Savannah River................................................................ 55

6.11 Predicted Total Annual Exposures to ${ }^{137} \mathrm{Cs}$ by Drinking Water and Ingestion of Finfish from the Savannah River.................................................... 55

6.12 Incremental Individual Cancer Mortality Risks from the Ingestion of ${ }^{137} \mathrm{Cs}$....... 56

6.13 Incremental Population Cancer Deaths from Annual Exposures to ${ }^{137} \mathrm{Cs}$.......... 57

6.14 Annual Discharges of ${ }^{137} \mathrm{Cs}$ from SRS Operations to Surface Waters.............. 58

6.15 Recalculated Incremental Individual Cancer Risks from Intakes of ${ }^{137} \mathrm{Cs}$ in Savannah River Water and in Savannah River Fish. 


\section{Glossary of Abbreviations, Acronyms and Symbols}

\begin{tabular}{ll} 
Term & Definition \\
\hline \hline (A)ED & (Annual) Effective Dose \\
$137 C s$ & Cesium-137 \\
$3 H$ & Tritium \\
AD & Annual Wholebody Dose \\
ADF & Annual Dose Factor \\
Average (Mean) & Arithmetic Mean \\
BCF & Bioconcentration Factor \\
BJ & Beaufort-Jasper \\
BNL & Brookhaven National Laboratory \\
BR & Breathing Rate \\
BW & Body Weight \\
CED & Committed Effective Dose \\
CERCLA & Comprehensive Environmental Response, \\
& Compensation and Liability Act (1980,1986) \\
CF & Conversion Factor or Constant (L-m-3, L/kg) \\
CS & Cesium \\
D & Duration \\
DE & Dermal Exposure \\
DF & Dilution Factor \\
DR & Diffusion Rate \\
DREF & Dose-rate Effectiveness Factor \\
DU & Dermal Uptake \\
EIP & Environmental Implementation Plan \\
EMS & Environmental Monitoring Section \\
EPS & Environmental Protection Section \\
F & Fraction \\
FEMP & Fernald Environmental Management Project \\
(F)FI & Annual Ingestion of Finfish (kg/y) \\
FIE & Finfish Ingestion Exposure (pCi/y) \\
Fr & Arithmetic Mean Fraction \\
Fsa & Fraction of Surface Area \\
GMean & Geometric Mean \\
GSD & Geometric Standard Deviation \\
HPI & Hazard Potential Index \\
HRS & Hazard Ranking System \\
HTO & Tritiated Water \\
ICRP & International Commission on Radiological Protection \\
IE & Inhalation Exposure \\
IEF & Inhalation Exposure Factor \\
IR & Incremental Individual Risk \\
Kp & Dermal Permeability Constant \\
LET & Linear Energy Transfer \\
LLNL & Lawrence Livermore National Laboratory \\
&
\end{tabular}


MEPAS

$\mathrm{N}$

NCRP

NE

NEPA

NPL

NRC

NTS

$\varnothing$

PDF

PEF

PR

PW

$r$

$R$

R-2, R-10

RBE

RBOF

$\mathrm{RC}$

RF

$\mathrm{RI} / \mathrm{FS}$

RT/H

$S A$

$S D$ or $S$

SREL

SRFS

SRL

SRS

TAE

USDA

USDOE

USEPA

USNRC

$\mathrm{V}$

VR

W

WF

W

WIE

[]

$\Delta$
Multimedia Environmental Pollution Assessment

System

Population Size (number of individuals)

National Council on Radiation Protection and

Measurements

Number of Events

National Environmental Policy Act

National Priorities List

National Research Council

Nevada Test Site

Transfer Efficiency (of a chemical from water to air)

Probability Density Function

Pathway Exposure Factor

Population Risk

Port Wentworth

Ratio (of concentrations)

Risk Factor or Coefficient

Savannah River Water-sampling Locations

Relative Biological Effectiveness

Receiving Basin for Offsite Fuel (H Area)

Risk Coefficient

Removal Factor

Remedial Investigation/Feasibility Study

(Gas constant $\times 293^{\circ} \mathrm{K}$ )/Henry's law constant

Surface Area

Arithmetic Standard Deviation

Savannah River Ecology Laboratory

Savannah River Forest Station

Savannah River Laboratory

Savannah River Site

Total Annual Exposure

U.S. Department of Agriculture

U.S. Department of Energy

U.S. Environmental protection Agency

U.S. Nuclear Regulatory Commission

Volume

Ventilation Rate

Water Use

Fraction of Fish Weight as Body Water

Annual Ingestion of Water $(\mathrm{L} / \mathrm{y})$

Water Ingestion Exposure (pCi/y)

Concentration

Change 


\section{UNITS OF RADIONUCLIDE ACTIVITY}

Radioactivity is quantified by the number of spontaneous energy emitting transformations per unit time -- a quantity known as activity. An example of a transformation is the decay of a radium-226 nucleus into a radon-222 nucleus, an alpha particle, and gamma rays. The unit of activity has historically been the curie $(\mathrm{Ci})$. One curie is equal to $3.7 \times 10^{10}$ disintegrations per second. Common prefixes to the curie include:

$$
\begin{array}{ll}
\text { millicurie } & (\mathrm{mCi})=10^{-3} \\
\text { microcurie } & (\mathrm{mCi})=10^{-6} \\
\text { nanocurie } & (\mathrm{nCi})=10^{-9} \\
\text { picocurie } & (\mathrm{pCi})=10^{-12}
\end{array}
$$

In the International System of Units (SI), the basic unit of activity has been redetined as one disintegration per second, known as the becquerel $(\mathrm{Bq})$. One curie is equal to $3.7 \times 10^{10} \mathrm{~Bq}$. Current practice in the United States is beginning to support the use of SI units. This document maintains the use of the old unit $(\mathrm{Ci})$, because the extensive data used in the analysis were recorded in units of picocuries per liter $(\mathrm{pCi} / \mathrm{l})$. Relationships to SI units are also described in the discussion of the dose factor for tritium. 


\section{INTRODUCTION}

Widespread environmental contamination has been documented at United States Department of Energy (USDOE) facilities. Human health risk assessments are increasingly being used to support decisions concerning remediation at these sites.

This study assessed health risks for potential problems at three USDOE facilities: (1) the Savannah River Site (SRS), near Aiken, South Carolina; (2) the Fernald Environmental Management Project (FEMP) in Fernald, Ohio; and (3) the Nevada Test Site (NTS), near Las Vegas, Nevada. The pilot study was a collaborative effort between the Biomedical and Environmental Assessment Group (BEAG) of Brookhaven National Laboratory (BNL) and the Health and Ecological Assessment Division (HEAD) of Lawrence Livermore National Laboratory (LLNL). BNL had primary responsibility for the risk assessments of the SRS and the FEMP, while LLNL took the lead in the assessment of the NTS. This volumie of the report, titled Filot Study Risk Assessment for Selected Problems at the Savannah River Site, presents risk assessments of impact on human health, for two potentially important problems identified at the SRS.

Current methods for assessing risk at USDOE facilities are generally excessively conservative or simplistic. Generic models, conservative parameter default values and assumptions are often used, and unrealistic exposure and land use scenarios are embedded in the analyses. These approaches are appropriate only as first level screening analyses and identify contaminants or pathways that are not important in terms of risk to human health.

Site and problem specific decisions about cleanup at USDOE facliities should be based on sophisticated state-of-the-science approaches to human health risk asse:sment. A more detailed, site-specific approach, based on realistic exposure scenarios and up-to-daia dose-response relationships would provide better information to USDOE, to regulatory agencies and to the public. Decisions concerning the need for remediation, the choice between remediation options, definition of cleanup goals, and funding and research priorities could then be assured of protecting the pub.:ic health in a scientifically based way.

This pilot project has three principle objectives:

(1) to develop scholarly, realistic, and quantitative health-risk assessments, based on state of the art scientific knowledge and methods, for several of the more important environmental and hazardous-waste problems at three USDOE facilities;

(2) to provide and demonstrate methods for realistic risk analyses that can be adapted for application at other sites in the USDOE complex;

(3) to improve significantly the scientific and technical foundation upon which remediation actions at USDOE sites are based, so that such risk-management decisions are scientifically defensible and fiscally sound.

We define a realistic and objective risk assessment to be one that:

(1) avoids unrealistic and conservativu exposure scenarios, and focuses on the development of reasonable and sensible scenarios; 
(2) replaces generic or inappropriate default assumptions with site-specific data;

(3) explicitly characterizes uncertainties in parameters and does not depend on conservative assumptions;

(4) uses site-specific transport and exposure models and depends on monitoring data for model calibration or input parameters;

(5) uses the latest scientific information in describing dose-response relationships;

(6) acknowledges that situations with very little data available to describe source terms or exposure routes cannot be assessed in a realistic way without additional data collection.

These situations can be addressed credibly and practically in screening level assessments.

Section 2 of this document summarizes the approaches to human health risk assessment commonly used at USDOE facilities, and outlines the method of realistic and objective risk assessment developed and demonstrated in the pilot study. Section 3 presents an overview of the Savannah River Site and develops much of the background data and information needed in the risk assessment. The bases for the choice of problems and contaminants analyzed in the pilot study are discussed in Section 4. The remainder of the document gives the risk assessments for the two problems studied at the SRS: (1) tritium in surface water and (2) Cs-137 in surface water. An appendix to this document discusses reasons for not performing a risk assessment on past reieases of chlorohydrocarbon solvents and their transport in groundwater under the SRS.

\section{RISK ASSESSMENTS FOR U.S. DEPARTMENT OF ENERGY SITES}

\subsection{Risk Assessment}

Risk can be defined in different ways. Cohrssen and Covello (1989) technically define risk as the possibility of suffering harm from a risk agent (i.e., chemical substance, organism, radioactive material, or other potential hazard). Consequently, the analysis of risk must describe the discharge of the risk agent, its transport and fate in an environmental media (i.e., air, soil, food, water) and any associated human exposure. Human-health risks are then calculated based on data and models that relate exposures to risk (Till and Meyer, 1983). The scope of such a risk analysis can range from a qualitative discussion to a careful, realistic and quantitative assessment of the likelihood of adverse human health effects (Cohrssen and Covello, 1989).

Several measures can be used to describe the probability that harm will result from exposure to a risk agent (adapted from Cohrssen and Covello, 1989):

- Individual lifetime risk: the estimated increase in probability that an individual will experience a specific adverse health effect over a lifetime as a result of exposure to a specified concentration of a risk agent; and

- Population risk: the number of deaths or adversely affected individuals in the exposed population.

The U.S. Environmental Protection Agency (USEPA) currently considers excess individual-lifetime cancer risks (assumed here to mean fatal cancer risks) within the range of $1 \times 10^{-4}$ (one-in-ten- 
thousand) to $1 \times 10^{-6}$ (one-in-a-million) to be acceptable (USEPA, 1991). A $10^{-6}$ excess individuallifetime cancer-mortality risk for the entire United States population (240 million in 1987, DHHS, 1990 ) would result in 240 premature deaths from cancer. Based on a lifetime expectancy of 70 years, this represents 3.4 deaths in addition to the 2.1 million annual deaths from all causes, including the 477,000 cancer deaths that occurred in the United States in 1987 (DHHS, 1990).

\subsection{Approaches to Risk Assessment}

Risk assessments cover a spectrum of complexity and accuracy, depending on the aims of the assessment and the level of certainty required of the results. Figure 2.1 outlines this spectrum of approaches to risk assessment that can be used to address environmental problems at USDOE facilities. The accuracy of the results of a risk assessment depends on the transport and exposure models used in the analysis, the variables used as input to the models, and the realism of the assumptions made concerning exposure scenarios, dose-response and risk factors, and receptors. Categorization and screening assessments are the approaches most frequently used at USDOE facilities.

\section{Categorization Assessment}

The least complex and accurate approach aims simply at identifying sites or problems of potential concern. In this report this approach is called a categorization assessment. The most widely used categorization assessment is the USEPA Hazard Ranking System (HRS: NCP, 1990) which generates numerical scores, based on general site information and a simple ranking model. Sites scoring above a certain level are included on the National Priorities List (NPL) under the Comprehensive Environmental Response, Compensation and Liability Act (CERCLA). This categorization system gives no information on the risks associated with environmental contamination at a site, and few site-specific data are required to generate an HRS score.

\section{Screening Assessment}

Screening assessments are the next level of complexity and accuracy in risk assessment.

Assessments of this type can range from simple conservative assessments of risk, assuming worstcase conditions, to more sophisticated analyses, based on multiple pathway models. The range of accuracy of the risk estimates produced by these approaches is driven by two major factors: the sophistication of the transport models and other algorithms used; and the accuracy of the input data and other assumptions contained in the analysis. These assessments give approximate estimates of individual and population risks but often rely on simplistic transport models. Conservative and unrealistic default assumptions are usually used to deal with uncertainty. The results of screening assessments can be used as a first step for identifying environmental problems requiring further assessment.

Two major kinds of screening risk assessments are commonly performed at USDOE facilities. These are assessments using a Multimedia Environmental Pollution Assessment System (MEPAS) model (Droppo et al., 1990; USDOE, 1988), and baseline risk assessments performed as part of Remedial Investigation/Feasibility Studies (RI/FS) required for Superfund sites (USEPA, 1989).

The (MEPAS) model was designed to use the results of an environmental survey performed by USDOE for its facilities to rank environmental problems in terms of risk. The model is a multiplepathway model that follows a contaminant from the source through various environmental media to 
man. The MEPAS model was designed specifically to produce relative rankings among environmental problems -- the Hazard Potential Index (HPI) produced by the model does not represent absolute estimates of health risk. There are a number of limitations to the model that make it inappropriate for use in a more detailed and accliidte approach to risk assessment. These limitations include the simple groundwater model included in the package, treatment of both cancer and toxicity risk in the same way (assuming no threshold), and difficulty in describing the time associated with exposure (Morris, 1990; Morris and Meinhold, 1988). The MEPAS model also uses toxicity values recommended by the US EPA that contain "safety factors" ranging from 10 to 1000 , and cancer risk factors that are based on a nurnber of conservative assumptions.

The USDOE environmental survey implemented the MEPAS model by using data and assumptions derived from initial investigations of potential problems at USDOE facilities. The detailed data and analyses required for an accurate estimation of risk were not available across all USDOE sites. Therefore, results of the survey were to be used simply to rank problems in terms of risk, and to help identify areas where further investigation and characterization were needed. For situations in which better data and more accurate assumptions are available, the MEPAS model can generate better estimates than those resulting from the USDOE environmental survey. However, the model is limited by design to producing screening assessments only.

Baseline risks assessments are performed in accordance with USEPA guidelines, and the specifics of the analyses are usuially dictated by the USEPA regional office responsible for the facility. Baseline risk assessments represent screening-level assessments because the conservative assumptions embedded in the analyses, and the common use of simplistic transport models produce approximate estimates of risk. A baseline risk assessment is conducted to estimate the risks associated with an identified operable unit prior to any remediation of a USDOE site that is listed on the NPL. The assumptions used in the assessments are designed to protect public health and are generally conservative, and tend to overestimate risks. The USEPA has identified a number of environmental transport models that it considers appropriate for use in these assessments. They range from simple 1-dimensional models to more complex computer codes.

The conservative assumptions contained in these baseline assessments include the previously described toxicity values and cancer risk factors, the use of worst-case conditions for land use, predicted environmental concentrations and exposure rates. The identified receptor for a baseline risk assessment is an individual receiving the "reasonable maximum exposure" [sic] (USEPA, 1989), whether or not she or he exists.

\section{Realistic Assessment}

The highest level of accuracy and complexity in a risk assessment process is a realistic assessment. Realistic assessments are usually performed for environmental problems identified by a screening assessment as presenting potentially significant risks. Conservative assumptions and safety factors are replaced in a realistic assessment by best estimates and reasonable exposure scenarios. Environmental concentrations, exposures and risks are presented in the form of distributions, where appropriate. More sophisticated transport models may be used, and predicted concentrations are compared to environmental monitoring data. Uncertainties and conservative assumptions are explicitly described. When data are not available for a realistic assessment, a screening analysis is performed instead. 


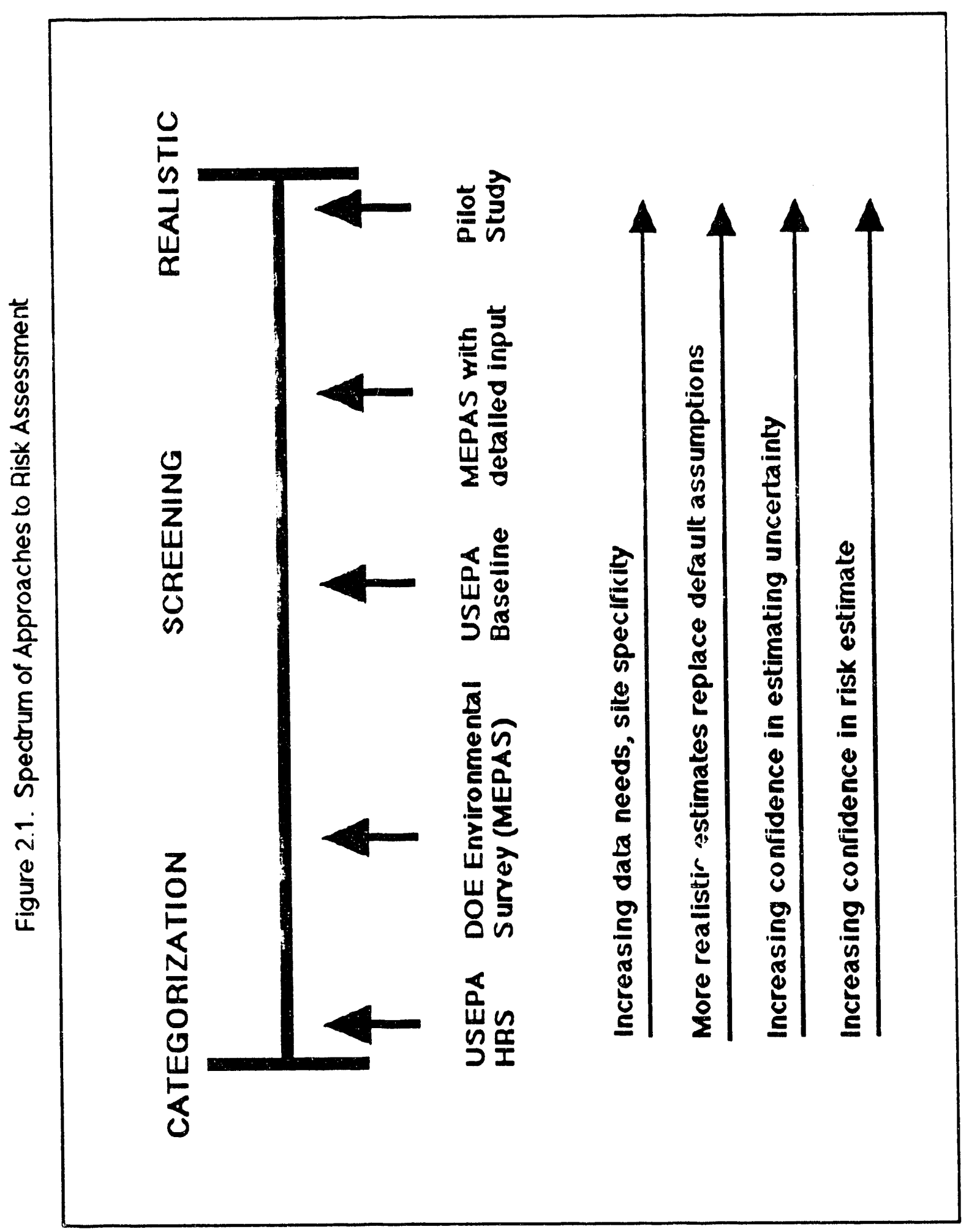

The screening assessments commonly used at USDOE facilities are appropriate for use as initial tools, or to satisty USEPA RI/FS requirements. Realistic assessments are the only way to produce reasonable, scientifically-defensible estimates of risk. Realistic assessments: provide better risk estimates to the USEPA, USDOE and to the public; form a better basis for remedial action decisions; and support cost-effective clean-up planning. 


\subsection{Pilot Study Approach to Realistic Risk Assessment for USDOE Facilities}

The risk assessments in this document and in the companion documents for the FEMP and NTS are based on a realistic and objective approach to risk assessment. The results of the assessments of the health risks associated with important environmental problems at the three USDOE facilities are well-documented, and scientifically-defensible. Where realistic assessments were not appropriate because of a lack of site- and problem-specific information, detailed credible screening assessments were performed to estimate the magnitude of potential health risks, and to determıne what additional data collection is needed. The next section outlines the methods used for developing realistic risk estimates for problems at USDOE sites, and subsequent sections provide additional descriptions of the constitutients of a "realistic" risk assessment.

\subsubsection{Specific Steps in the Analysis}

Figure 2.2 outlines the procedure developed in this pilot study for assessing human health risk at USDOE sites. The steps in this procedure are described in more detail below.

1. Development of Site Overview. The first step is to develop a site description that includes relevant background information on the physical setting of the site, nearby populations and land uses, local meteorology, the direction of groundwater flow, and the uses of ground and surface water.

2. Problem and Contaminant Identification. The important potential problems and related contaminants in terms of potential human exposures and risks are identified.

3. Source Term Characterization/ Environmental Fate and Transport. The major chemical fate and transport pathways are described for the contaminants of concern. The temporal and/or spatial variations of a contaminant's concentration in environmental media are predicted. Monitoring data and other available information are used to estimate the source term. Environmental transport models, adapted to the specific site, are used to predict contaminant concentrations.

4. Realistic Estimates of Exposure Rates. Predicted concentrations of a particular contaminant in environmental media are used to estimate potential human exposure to the substance of concern. These estimates are based on reasonable estimates of exposure parameters such as water intake, food intake, and residence time. Site-specific data are used when available. This step also includes the development of reasonable land-use scenarios.

5. Realistic Dose-response Relationships. Dose-response relationships, which relate toxic endpoints to exposures or doses are constructed or are identified in the literature. The safety factor approach used by the USEPA is replaced in the estimated relationship between dose and effect for toxicants by an explicit consideration of uncertainty. Cancer risk factors are described as distributions about the best estimate available.

6. Risk Characterization. Finally, the potential individual and or population health risks and/or hazards for a specific environmental contaminant are quantified. Where possible, these risks are described as probability distributions. 
Figure 2.2. STEPS IN THE ASSESSMENT

Development of site overview

Identification of principal problems

and related contaminants

Source-term characterization

Enyironmental fate and transport

Realistic estimates of exposure rates

Realistic dose-response relationships

Risk characterization 


\subsubsection{Methods and Assumptlons}

\section{Identification of Receptors}

Receptors are either people who are currently exposed to the pollutant of interest, or people who have a potential for such exposure. Currently exposed people include onsite populations (i.e., workers), and local or regional populations that are exposed because of environmental transport processes (e.g., wind, surface and groundwater movement). Potentially exposed people include people that reside in the path of a plume that is expected to reach them in the future, people that gain entry to the site as a result of a loss of institutional control, and additional people who will be exposed as a result of population growth.

\section{Development of Exposure and Land Use Scenarios}

It is assumed that land uses in the future conform to current activities, or to current activities on nearby land, unless there is compelling evidence to the contrary. Either ground water or nearby surface water is assumed to be the source of drinking water, unless there is evidence against such usage.

The assumption of the maintenance or loss of institutional control at a DOE facility can be critical to the results of a risk assessment when the bulk of the identified contamination is onsite in soil or water. A loss of institutional control may require the use an intruder scenario, and a scenario assuming the possibility of farming or a family living onsite. For problems for which institutional control affects the risk assessment, two analyses are done. The first assumes a maintenance of institutional control in perpetuity. The second assumes loss of institutional control after 100 years.

\section{Environmental Transport}

Contaminant concentrations in air, ground water, surface water and food are predicted by using environmental transport models appropriate to each site, each problem and the available data. Where complex site-specific transport models were developed by the USDOE or site contractors. these models are consiciered for use in the assessments. When a large amount of historical data is available, empirical models are used in place of physics-based models to relate site contaminant discharges to environmental concentrations at receptors.

When sites and source terms are poorly characterized, more elementary models are used. For use in a screening analysis, such models provide appropriate estimates of future environmental concentrations of the principle contaminants of concern.

\section{Exposure Routes and Parameters}

Each route of exposure is analyzed for its contribution to the total exposure of a person to a contaminant. The analysis relates the concentration of contaminant in a medium (e.g., $\mathrm{pCi} / \mathrm{L}_{2} \mathrm{O}$. $\mu \mathrm{g} / \mathrm{kg}$ soil) to the total amount of the medium to which an individual is exposed. The data used in the analyses include distributions of personal exposure factors (e.g., rates of breathing, ingestion of fish and other activities). These distributions reflect population characteristics in the United Sates, either obtained from published sources or developed from available data. Specific pathways of exposure are not analyzed further, when documented evidence shows that they are not appropriate to the specific problem. 


\section{Dose-response Relationships and Risk Characterization}

Dose-response functions per unit of contaminant exposure are obtained from the literature, or are developed from the available data. For each contaminant, a dose response function is applied to the total exposure to determine the total dose.

Hazards are characterized qualitatively and quantitatively for carcinogenicity and/or toxicity. Risk functions (factors) are also obtained from the literature, or are developed from the available data. These risk factors, expressed as risk per unit dose, or risk per unit intake, are applied to the total doses of contaminants to estimate the risks. In most cases the risks are estimated for cancer mortality, including individual lifetime risks and population risks. These risks are expressed as central values (average and/or median) and uncertainties (standar.y deviation and cumulative upper $95 \%$ probability value). Graphic examples of the ranges of risks are also reported.

For toxic effects other than cancer, the risks are expressed as the probability of an individual incurring the effects, including both a central value and uncertainty in the expression.

\section{Probabilistic Assessment and Uncertainty}

A realistic and probabilistic assessment uses the range of possible values for parameters and variables, rather than relying on single values. When appropriate, the risk assessments use distributions of values, rather than single estimates, to produce probabilistic analyses of risk (as demonstrated simplistically in Figure 2.3). For example, the rate of drinking water intake by individual receptors is represented by a distribution of values, instead of the average (or maximum) rates commonly used in USEPA and USDOE risk calculations. This approach to risk assessment allows an estimate of the uncertainty associated with an "average" or "worst-case" risk estimate. As described above, the result of such an assessment for cancer mortality risk is a distribution that can be presented graphically (Figure 2.3), in addition to presenting the mean and $95 \%$ Upper Confidence Limit (i.e., cumulative upper $95 \%$ value).

Many of the probabilistic analyses in the pilot study were produced with a Monte Carlo analysis, using Crystal Ball@ (Decisioneering, Boulder, CO) software. In a Monte Carlo analysis, a sample from the distribution of a variable is placed into a simulation run (iteration) to interact with samples from other variables. The frequency of sampling within a distribution of a variable depends upon the relative frequency of a value in that distribution (Paustenbach et al., 1990).

\section{Inadequate Data and Screening Assessment}

Part of the risk assessment process developed in this pilot study is the exercise of professional judgment concerning the amount (and quality) of site characterization and source term data needed to justify the application of the sophisticated models and probabilistic methods required for a "realistic" assessment. When source term or site characterization data are inadequate, a screening level assessment is the only feasible initial approach to a problem. The approach used in this pilot study was: to perform such screening assessments when the available data were limited (eliminating unnecessary conservatism where possible); to document explicitly all assumptions used in the analysis; and to draw conclusions on the need for additional data collection. 
Figure 2.3. Probabilistic Risk Assessment Example: Estimation of individual lifetime risk of cancer mortality from ingestion of tritium in drinking water.

Step 1. a). Develop an assumption about the distribution of tritium concentations in drinking water $\left(\left(^{3} \mathrm{H}\right)_{\text {water }}\right)$.

b). Develop an assumption about the distribution of drinking water intake (WI).

c). Calculate exposure to tritium in drinking water (WIE).

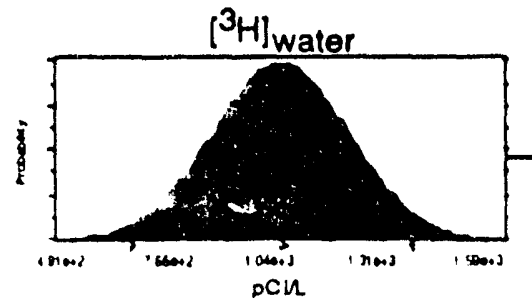

Calculate:

$[\mathrm{H}]_{\text {water }} \times W I=$ WIE

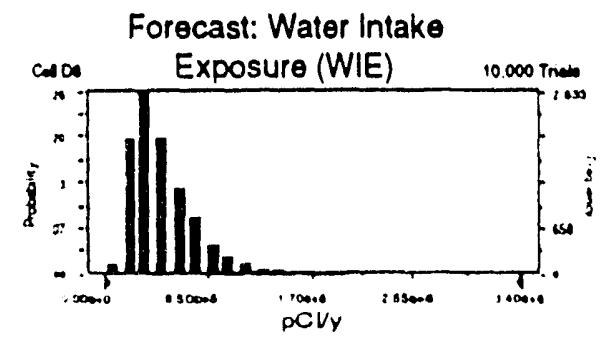

Step 2. a). Develop an assumption about the dose factor for tritium ingestion (Df).

b). Develop an assumption about the risk factor for tritium ingestion (Rf).

c). Calculate incremental individual lifetime risk for cancer mortality (IR).

Forecast: Water Intake
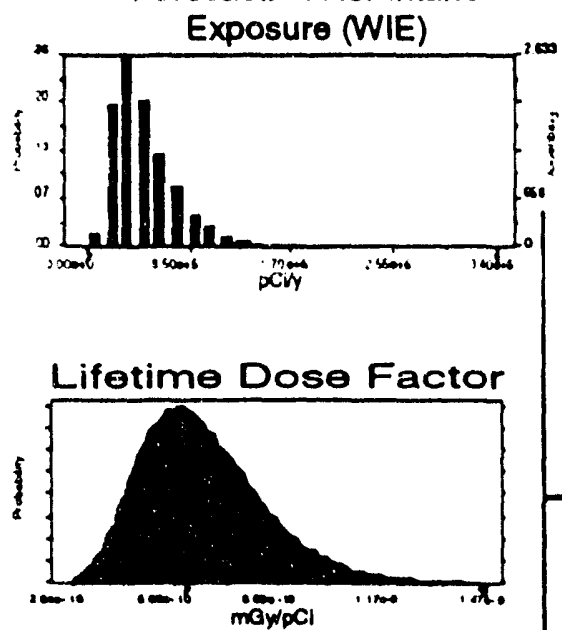

Calculate:

WIE $\times$ Df $\times R f=I R$

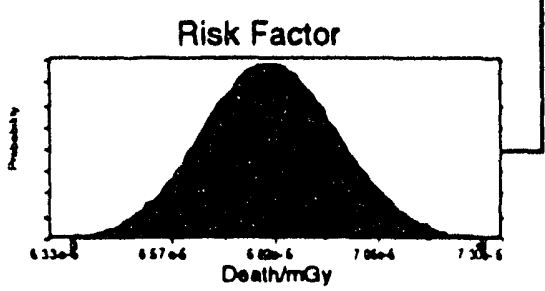

Forecast: Incremental Individual Lifetime Risk per Year of

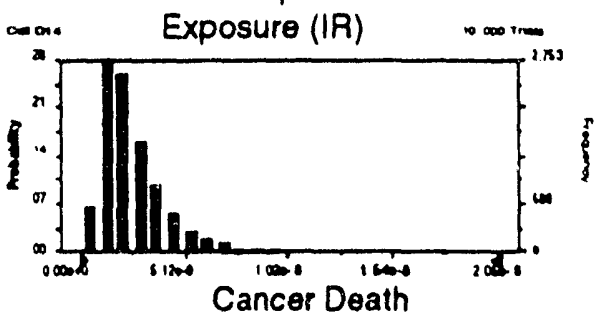


Figure 3.1. The Savannah River Site

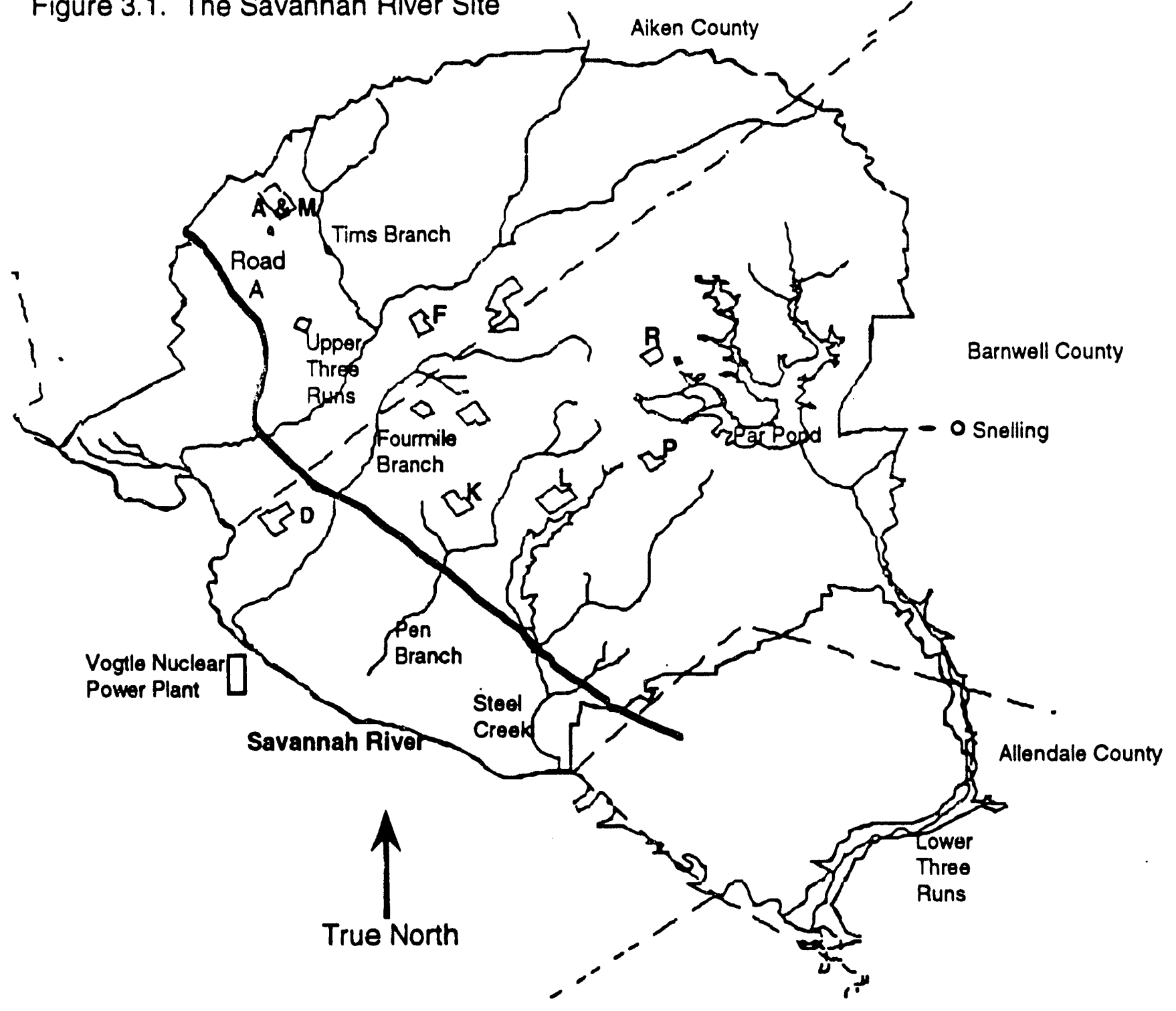

3 OVERVIEW OF THE SAVANNAH RIVER SITE

3.1 Regional Setting and Physical Environment (Cummins et al., 1990, 1991,

\subsubsection{Location}

The Savannah River Site (SRS) occupies an area of approximately 300 square miles along the Savannah River, principally in Aiken and Barnwell Counties of South Carolina (see Figure 3.1). The Reactor and Separations Areas are centrally located, but other facilities are near the perimeter of the site. The area immediately surrounding the SRS is primarily rural. 


\subsubsection{Climate}

The climate is mild, with an average frost-free season of approximately $24 \epsilon$ days. Average monthly temperatures range from $45^{\circ} \mathrm{F}$ in January to $810 \mathrm{~F}$ in July. Average annual (1952-1982) rainfall of 48 inches is evenly distributed throughout the year: Summer, 33\%; Fall, 19\%; Winter, $21 \%$; Spring, $27 \%$. Snowfalls and freezing rain are infrequent in the area. Average daily relative humidity in the vicinity of the plant ranges from 43 to 90 percent.

The SRS lies in a region that averages 8.5 tornadoes per year, mostly in the Spring. Three tornadoes have been confirmed on the plant site or vicinity from 1951 to 1983 . On an annual basis, winds are redominantly from the west-northwest. The average measured wind speed, from 1951 through 1981, was 7.2 miles per hour in Augusta, Georgia, approximately 25 miles to the Northwest of the site. Calms, and winds below 3.3 miles per hour, reportedly occur about 33 percent of the time.

\subsubsection{Hydrology}

The Savannah River forms approximately 35 miles of the southwestern boundary of the SRS (Figure 3.1). Five major streams on the SRS feed into the river: Upper Three Runs Creek; Four Mile Creek; Pen Branch; Steel Creek; and Lower Three Runs Creek. The streams receive effluents from various operations on the site. These streams are not used as commercial sources of water.

The total mean discharge of all five streams through 1990 is approximately $13 \mathrm{~m} 3 / \mathrm{s}$. This figure may include some water pumped out of the Savannah River for operational use and then returned to SRS streams. Water discharges of all pertinent stream systems on the SRS, including the additional discharge from plant operations, are summarized in Table 3.1.

Table 3.1 Savannah River Tributary Discharges Through 19901 Measurement Location

Discharge $\left(\mathrm{m}^{3} / \mathrm{s}\right)$

\begin{tabular}{|llll|}
\hline Intersection of Upper Three Runs with Road A & 4.871 & 2.351 & 34.834 \\
Intersection of Fourmile Creek with Road A & 0.700 & 0.19 & 30.019 \\
Intersection of Pen Branch with Road A & 1.376 & 0.566 & 26.847 \\
Intersection of Steel Creek with Road A & 3.455 & 0.878 & 11.611 \\
Lower Three Runs near Snelling & 2.696 & 0.368 & 20.915 \\
\hline
\end{tabular}

1Bennett et al., 1990

The expected future discharge of cooling water from K-Reactor, when operational, will be $1.8 \mathrm{~m}^{3} /$ : (USDOE, 1990). This flow rate reflects operational use of a cooling tower. Thus, stream wate volumes leaving SRS should vary from approximately $6 \mathrm{~m}^{3} / \mathrm{s}$ to a maximum of about $126 \mathrm{~m}^{3} / \mathrm{s}$ when flows from the K-Reactor cooling tower are added to either the sum of the minimal or the sum of the maximal discharges in table 3.1. The maximal discharge is probably overestimated because it includes rates of water flow resulting from discontinued previous operations. 


\subsubsection{Physiography and Hydrogeology}

Two distinct physiographic subregions exist at the SRS. These are Pleistocene coastal terraces (below elevation 270 feet) and the Aiken Plateau (above elevation 270 feet). The Wicomoco Terrace, the floodplain of the Savannah River, is covered by a dense forest typically composed of bald cypress and tupelo gum trees. The Brandywine and Sunderland Terraces have gently rolling topography. They are characterized by bottomland hardwood forest and loblolly pine, oak, birch, poplar, and gum trees. The Aikon plateau is characterized by hilly upland areas dissected by streams. Longleaf-pine forest and scrub oak are the typical vegetation in the upland areas.

Sandy sediments of the South Carolina Upper Coastal Plain lie beneath the SRS. The sediments constitute a multilayer hydrologic system in which aquifers are separated by confining beds of clayrich materials. Hydraulic properties vary for each of the hydrologic units, depending on their lithology. From deepest to highest, groundwater occurs in the following formations at the SRS: Tuscaloosa (= Cretaceous), Ellenton, Congaree, McBean, Barnwell, Hawthom, and Surficial. The depth of stream incision of the Aiken Plateau typically controls groundwater flow direction. As a result, shallow groundwater flow is governed by the location (depth) of small creek valleys: intermediate groundwater flow is governed by the incision of the major tributaries to the Savannan River, and deep groundwater flow (e.g., the Tuscaloosa Formation) is govemed by the Savannan River valley.

The multilayer hydrologic system results in lateral flow that varies in direction with depth. In addition, both downward and upward vertical gradients occur at the SRS. Groundwater head decreases with increasing depth in the Northwest portions of the SRS. This results in potential direct recharge of water to deeper sediments. At other areas of the SRS, there is an upward vertical gradient (or head reversal) between the Tuscaloosa and Congaree Formations.

\subsubsection{Population}

Most of the site's environs are rural. Average population density in the counties surrounding SRS ranges from 23 to 560 people per square mile (pre1990 census). Aiken, South Carolina (population 15,000), lies approximately 20 miles to the North, and metropolitan Augusta, Georgia (population $>250,000$ ), as previously stated, lies approximately 25 miles to the Northwest of the SRS. The total population within a 50-mile radius of the SRS is approximately 631,000 (Hamby, 1991).

\subsubsection{Land Use}

The SRS is bounded on the Southwest by the Savannah River and on the West, north and east by privately and publicly owned land. Approximately $40 \%$ of the site's environs are forested. The major farm crops in the region are cotton, soybeans, corn, small grains. Beef cattle are also raised. Major industrial and manufacturing operations in the vicinity of the SRS include textile mills, plastic and paper products, and chemical processing plants. A commercial nuclear power plant, the Vogtle Plant (Figure 3.1), lies directly across the Savannah River, on the southwest border. 
Figure 3.2. Locations of Major Water Treatment Plants Using Savannah River Water.

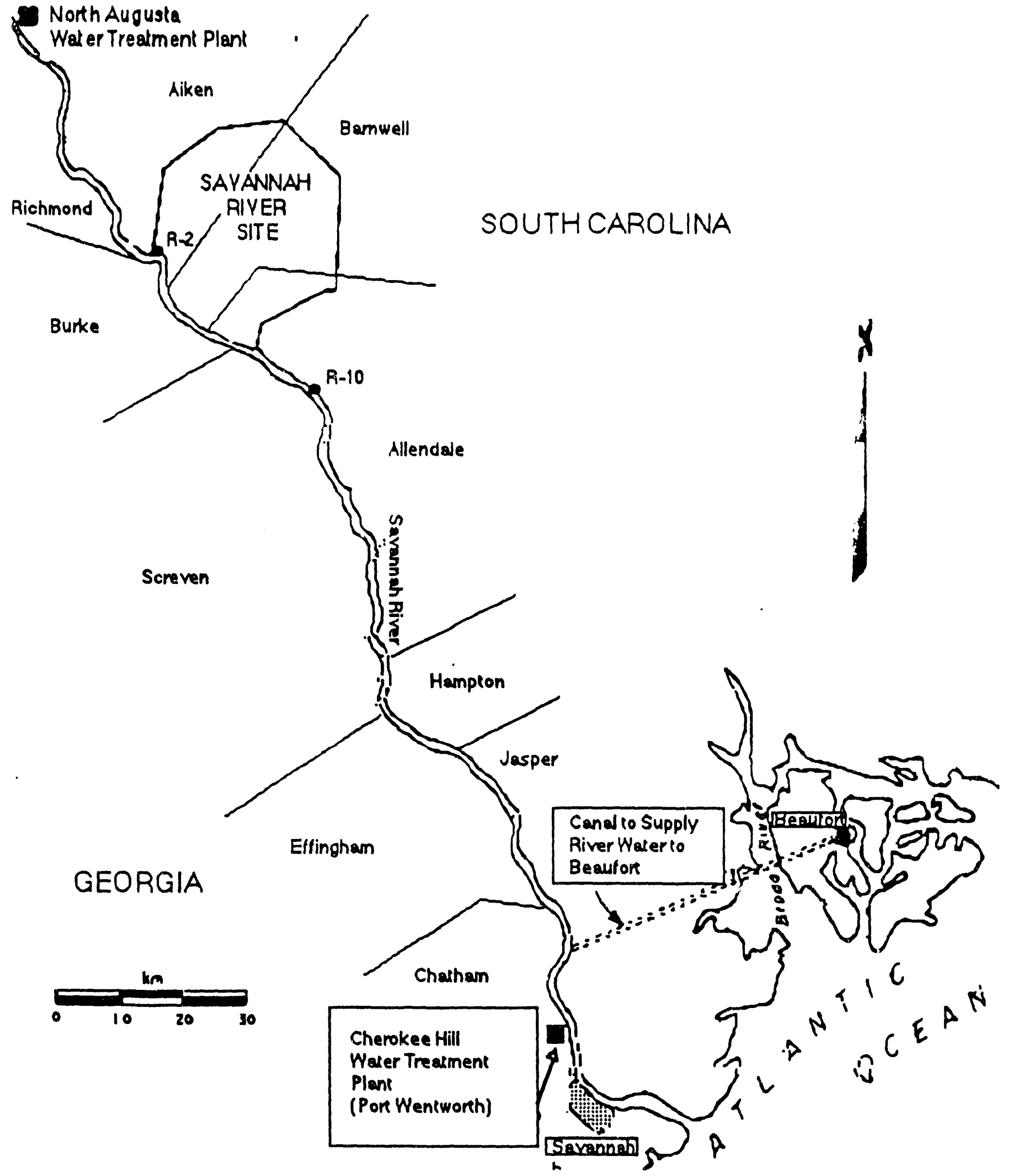




\subsubsection{Use of Surface and Ground Water}

The SRS draws water from the Savannah River and Par Pond (Figure 3.1) to cool reactor operations. Effluent wastewater treatment plants are expected to deionize, filter and monitor the liquid effluents from operations at SRS. Tritium is not be removed by these treatments. Trace amounts of other radionuclides are expected to also be released into streams and the Savannah River.

Augusta, GA and North Augusta, SC. draw water from the Savannah River to serve as the raw supply for their municipal systems. The water is removed upstream from the site (Figure 3.2). Onsite, the operators of D Area (Figure 3.1) also used the Savannah River as a raw water supply until 1990; they currently use bottled water (Cummings et al., 1991). Savannah River water is not used for drinking yithin 80 miles downriver of the SRS. The nearest downriver users are 66,000 people at Wentworth, GA, and near Hardeeville, SC (Beaufort and Jasper Counties). The Cherokee Hill Water Treatment Facility in Port Wentworth, Georgia supplies water to an industrial population of 15,000, but not to the public (Hamby, 1991). A water treatment facility supplies water to 51,000 people in Beaufort and Jasper Counties in South Carolina. Expansions of the water treatment plants are expected to provide residential water supplies to 200,000 people in Savannan, GA (Port Wentworth) and 117,000 people in Beaufort and Jasper Counties by the year 2000 (pp. 322-324. USDOF., 1990).

Recreational use of the Savannah River is greater upstream from the SRS than it is downstream. River water downsiream from the site is not currently used for irrigation ( $p$. 324, USDOE, 1990; Hamby, 1991, 1992).

\subsection{Site Description and Site Operations}

Major site facilities include five nuclear reactors, a heavy water production plant, a fuel and target fabrication plant, a naval fuel materials facility, two chemical separations plants, the Defense Waste Processing Facility, the Savarnah Fiver Laboratory (SRL), and a process development laboratory that supports production operations. Many other supporting facilities are located on the SRS. All five reactors were inoperative iri 1989. Although the USDOE recently proposed the continued use of the $K$, the $L$ and the $P$ Reactors for defense and nondefence purposes (pp. $V$ - $v i$, USDOE, 1990), current plans are to operate K Reactor only (Todd V. Crawford, personal communication). Nuciear fuels and targets, together with other reactor components, are manufactured in the fuel and target fabrication facility.

Reactor-produced products are recovered in the chemical separations areas. Plutonium and uranium are separated from other fission products by complex chemical processes. These areas also have facilities for purification and packaging of tritium, and for storage of fission product wastes.

Reactors and separations plants are located near the center of the site; other facilities are located near the perimeter. SRS production areas and effluent streams are shown in Figure 3.1. Operations in 1989 are summarized in Table 3.2. 
Table 3.2 Operating Status for SRS Facilities During 1989 (Table IP-1 in Cummins et al., 1990)

\begin{tabular}{|c|c|}
\hline $\begin{array}{l}\text { Reactor Areas } \\
\text { C Area } \\
\text { K Area } \\
\text { L Area } \\
\text { P Area }\end{array}$ & $\begin{array}{l}\text { Process down } 100 \% \\
\text { Process down } 100 \% \\
\text { Process down } 100 \% \\
\text { Process down } 100 \%\end{array}$ \\
\hline $\begin{array}{l}\text { Separations Area } \\
\text { H-Area Plutonium Process } \\
\text { Chemical Separation Facility } \\
\text { Tritium Facilities } \\
\text { RBOF Facility } \\
\text { Waste Compactor } \\
\text { Beta-gamma Incinerator } \\
\text { Waste Management Facility }\end{array}$ & $\begin{array}{l}\text { Process down } 100 \% \\
\text { Process operational } 10 \% \\
\text { One process operational } 40 \% \\
\text { Normal operation } \\
\text { Process operational } 25 \% \\
\text { Process down } 100 \% \\
\text { Normal operation }\end{array}$ \\
\hline $\begin{array}{l}\text { F-Area Plutonium Process } \\
\text { Chemical Separation Facility } \\
\text { Plutonium Fabrication Facility } \\
\text { A Line } \\
\text { Naval Fuel Materials Facility } \\
\text { Laboratory Facility } \\
\text { Laboratory Facility }\end{array}$ & $\begin{array}{l}\text { Process operational } 29 \% \\
\text { Process operational } 30 \% \\
\text { Process down } 100 \% \\
\text { Process operational } 40 \% \\
\text { Normal operation } \\
\text { Process operational } 50 \% \\
\text { Normal Operation }\end{array}$ \\
\hline $\begin{array}{l}\text { Tank Farms ( } F \text { and } H \text { Areas) } \\
\text { Effluent Treatment Facility }\end{array}$ & $\begin{array}{l}\text { Normal Operation } \\
\text { Normal Operation }\end{array}$ \\
\hline $\begin{array}{l}\text { Raw materials } \\
\text { Fuel Fabrication Facility } \\
\text { Fuel Fabrication Facility } \\
\text { Laboratory Facility }\end{array}$ & $\begin{array}{l}\text { Process operational } 35 \% \\
\text { Process down } 100 \% \\
\text { Normal Operation }\end{array}$ \\
\hline Defense Waste Processing Facility & Process down $100 \%$ \\
\hline Savannah River Laboratory & Normal Operation \\
\hline
\end{tabular}

${ }^{1}$ Status of operation refers to the period that the facility was operating during the year.

Normal operation - facilities operated all year

Process operational - facilities operated for percentage of time stated

This information was obtained from Health Protection Operations managers in each facility.

\subsection{Environmental Concerns}

Radioactive (primarily tritium) and nonradioctive chemicals have been released into the onsite ground water from seepage and chemical waste storage basins, and from overflows of the basins. Nonradioactive pollutants (e.g., degreasers) have also entered the ground water from leaks in 
conduits to waste storage facilities. Major portions of all the releases have entered the Savannah River, either directly from the ground water or by way of the onsite streams that drain into the river.

For radioactive contaminants, tritium releases are considered the most immediate environmental health problem. For the SRS, tritium forms the biggest component of radioactive contaminant release and human exposure (Murphy et al., 1991). Release of tritium predominantly occurs through stack emissions of tritiated water and the gaseous element into the atmosphere. Inadvertent releases of tritium have also taken place. For example, tritium has been released from leaks in the heat exchange system into water that eventually went into suiface water. Tritium represents more than $99 \%$ of the radionuclide activity in the Savannah River.

Releases of other radionuclides (e.g., ${ }^{137} \mathrm{Cs}$ and $90 \mathrm{Sr}$ ) to the Savannah River, although in much smaller quantities than tritium, are of concern because of their longer half-lives and bioaccumulation.

There are also concerns for possible long-term problems associated with high-level nuclear wastes, stored stored at the site (e.g., the F-and H-area tank farms).

\subsection{Environmental Monitoring and Site Restoration}

Table 3.3 Types of Samples Analyzed in the Radiological Monitoring Program (Table IP-2 in Cummins et al., 1990)

\section{Air}

Thermoluminescent Dosimeters

Surface Water

rivers

streams

seepage basins

\section{Ground Water \\ Milk}

Food

(i.e., eggs, chickens, meats, fruits, grains, collards)

\section{Drinking Water}

Wildlife

fish

crabs and oysters

deer and hogs

furbearers

(i.e., opossums, foxes,

raccoons)

turtles

ducks

Rainwater

Soil

Sediment

Vegetation

\subsubsection{Environmental Monitoring Program}

The SRS maintains an environmental monitoring program composed of routine and nonroutine radiological and nonradiological surveillance activities, environmental protection programs, and National Environmental Policy Act (NEPA) compliance activities. SRS complies with federal, state and local environmental permitting processes. A wide variety of environmental management and research programs are conducted each year by the SRS, Savannah River Laboratory (SRL), Savannah River Ecology Laboratory (SREL.), and the Savannah River Forest Station (SRFS) under a comprehensive Environmental Implemeintation Plan (EIP) that sets specific site environmental policies, objectives and implementatior, strategies. The Environment and Health Protection 
Department (EHP) coordinates these activities through its subsidiary Environmental Monitoring Section (EMS) and Environmental Protection Section (EPS).

Each year, monitoring for radioactive materials in various environmental media is performed in a 2,000-square-mile area in the immediate vicinity of the SRS. Representative samples of different types are collected from an additional 30,000-square-mile area (Table 3.3).

Table 3.4 Samples Analyzed in the Nonradiological Program (Table IP.3 in Cummins et al., 1990)

\begin{tabular}{|ll|}
\hline $\begin{array}{l}\text { Alr } \\
\text { Surface Water } \\
\text { rivers } \\
\text { streams }\end{array}$ & $\begin{array}{l}\text { Ground Water } \\
\text { Drinking Water } \\
\text { Sediment } \\
\text { rivers } \\
\text { streams }\end{array}$ \\
\hline Seepage basins & \begin{tabular}{c} 
Fish \\
\hline
\end{tabular} \\
\hline
\end{tabular}

With few exceptions, nonradiological monitoring (Table 3.4) is limited to samples collected onsite. Analyses of samples from this program are carried out by offsite contractors (Cummins et al., 1990).

\section{PROBLEMS TO BE STUDIED IN RISK ASSESSMENT}

\subsection{Criteria for Problem Selection}

Problems to be assessed in this pilot study were chosen using a number of factors and criteria, and were selected based on a qualitative critical review, rather than a formal ranking system. Criteria included identification by DOE and contractor site managers, results of screening assessments, and professional experience. For example, concerns identified by DOE's Multimedia Environmental Assessment System (MEPAS), as implemented by a DOE Environmental Survey, were considered for this assessment. Professional knowledge and experience were also applied to identify potentially important problems that received a low score from the MEPAS model. Public and Department of Energy concerns were important factors in choosing problems to analyze, and emphasis was placed on circumstances where offsite transport and exposure have already occurred.

\subsection{Problem 1: Tritium Release to the Savannah River}

Many SRS operations that produce and handle radionuclides release some tritium to the environment. Reactor operations, recoveries of transuranic elements, recovery of tritium, laboratory research, and heavy-water reprocessing release tritium. These releases enter the atmosphere, site streams and the ground. Most of the tritium has been released due to routine operations and waste storage. A small portion of the releases was from inadvertent (unplanned) releases. Many of the tritium releases occurred during the early years of operation. Of about 24 million total curies (Ci) 
released to the atmosphere and streams through 1988, about 13 million $\mathrm{Ci}$ have decayed. Thus, 11 million residual $\mathrm{Ci}$ are distributed in the world environment.

An additional 7 million $\mathrm{Ci}$ were placed into the ground in the seepage basins and burial ground. Most of this inventory has been depleted by a combination of radioactive decay, evaporation, and groundwater transport resulting either in release to the atmosphere by way of botanical uptake and transpiration, or discharges to surface waters. About 2.3 million $\mathrm{Ci}$ of the inventory remain (Murphy et al., 1991).

Transport through the shallow groundwater aquifer has been documented, but movement offsite in ground water has not been detected. Instead, hydrologic mechanisms cause drainage from seepage basins to enter surface waters onsite after migration through the shallow aquifers. The groundwater aquifers outcrop to five major onsite stream systems that feed into the 35 mile Savannah River at various places along its border with the SRS.

Tritium in surface water was selected for this investigation as a demonstration of a current regional concern. The DOE survey implementation of MEPAS ranked this topic in Hazard Potential Index (HPI) Group 7. Group 7 is generally driven by larger receptor populations with moderate concentrations and/or toxicity of the contaminants. Problems in this group also include small receptor populations where the toxicity or concentration is high.

The SRS facilities began operations in 1954. Of the radionuclides released by this facility into the Savannah River, tritium is of special importance. This arises partly because of its biological properties, partly because of its of 12.3 year half-life, and partly because it has been released into the environment from the SRS for many years. Also contributing to its significance is that this single radionuclide represents more than $99 \%$ of the radionuclide activity in the Savannah River. As a result, tritium is a prime example of a radionuclide of current and immediate concern. Calculations show that the resulting exposures to offsite populations due to tritium are the most important exposures originating from any radionuclide (Murphy et al., 1991).

The calculations in the current assessment were based both on tritium data that was available through 1989, and on dose and risk factor information that was available early in 1991.

Tritium is readily taken up by humans and other organisms in the form of tritiated water (HTO) and as the free radionuclide. As HTO, it is freely exchangeable between all physiological compartments and is distributed throughout the body. Tritium also exchanges with elemental hydrogen in organic molecules. Municipal water supplies drawn from the Savannah River are expected to expose a population of approximately 317,000 to HTO in water downstream from the SRS by the year 2000 (USDOE, 1990).

\subsection{Problem 2: Cesium $\left({ }^{137} \mathrm{Cs}\right)$ Contamination in the Savannah River}

There is a similar concern for the health effects of $137 \mathrm{Cs}$. Radioactive cesium has been released to the Savannah River in a manner similar to tritium, and is present in surface waters in trace amounts (USDOE, 1990). ${ }^{137} \mathrm{Cs}$ is also present in stream sediments within the Savannah River system atand downstream from the SRS. The calculations in the current assessment were based on ${ }^{137} \mathrm{Cs}$ data that were available through 1990 . When ingested by humans, ${ }^{137} \mathrm{Cs}$, like potassium, is taken up and concentrates intracellularly throughout the body. 


\subsection{Problems Identified for Future Assessments}

A basic criterion for selecting problems for this pilot study was the concern with more immediate hazards from potential near-term exposures. Large quantities of high-level nuclear waste storage onsite may pose significant questions of longer-term risks.

Risks resulting from releases of nonradioactive contaminants to ground-and surface waters are additional concerns. For example, degreasing solvents were released some years ago to ground water in the A \& M Areas. However, the available hydrogeological evidence suggests that presently they pose no offsite health risks to neighboring receptors (see Appendix 1).

Inadvertent releases of hazardous materials and catastrophic events (e.g., earthquakes) form a set of concerns that require analyses on an individual basis, because of wide variations in possible scope and magnitude. For the current analyses, previous inadvertent releases of radionuclides are included in the source terms of the risk assessments.

\section{HUMAN HEALTH RISK ASSESSMENT FOR TRITIUM RELEASED TO THE SAVANNAH RIVER}

\subsection{Major Steps in the Risk Assessment for Tritium Released to the Savannah River.}

The six general steps described below were applied to analyses of cancer mortality risks from tritium:

1. Define the the problem (section 5.2);

2. Identify release scenarios, develop estimates of source terms and predict environmental [3H] concentrations (section 5.3);

3. Review information on transport and fate of $3 \mathrm{H}$ in the Savannah River system (section 5.4)

4. Estimate exposures (section 5.5);

5. Review dose-response information; identify appropriate risk factors (section 5.6);

6. Estimate excess lifetime individual and population risks (section 5.7).

Monte Carlo analytical calculations were performed with values, or Latin Hypercube sampling of distributions of values, using Crystal Ball ${ }^{\circledR}$ software (Decisioneering Corp., Boulder, CO) in conjunction with spreadsheets constructed in Excel ${ }^{\circledR}$ (Microsoft Corp., Seattle, WA) on a Macintosh ${ }^{\circledR}$ computer (Apple Corp., Cupertino, CA).

\subsection{Problem Summary}

Tritium is a weak beta emitter, with a half-life of 12.3 years. Elemental tritium has the same chemica properties as hydrogen and is rapidly oxidized into tritiated water in the environment. Tritium is readily taken up by humans and other organisms in the form of tritiated water and as HT. Tritium is distributed throughout the body. As water it is freely exchangeable between all physiological 
compartments. As the radionuclide, tritium exchanges with elemental hydrogen in organic molecules.

Many operations that produce and handle radionuclides at the SRS release tritium to the environment. Examples include reactor operations, recoveries of transuranic elements, recovery of tritium, laboratory research and heavy water rework. The released tritium goes to the atmosphere, site streams, the ground and ground water. Most of the tritium has been released due to routine operations and waste storage. A small portion of the total release was from inadvertent (unplanned) releases.

Release of $3 \mathrm{H}$, as HTO, occurs either directly into surface streams, or indirectly into surface waters following release to seepage and waste storage basins, or by aerial deposition. By the year 2000 , raw water drawn from the Savannah River for municipal supplies is expected to expose approximately 317,000 people to HTO in water downstream from the SRS (USDCE, 1990).

\subsection{The Sources of Tritium at the SRS}

\subsubsection{Direct and Indirect Discharges}

Nuclear fuels and targets, together with other reactor ccmponents, are manufactured in the fuel and target fabrication facility. The reactors at the SRS are fueled with uranium, and are moderated and cooled by circulating heavy water in a closed system through heat exchangers. Water from the Savannah River and Par Pond, a man-made cooling water impoundment covering 2,640 acres, is used as a coolant in the heat exchangers.

Cooling-water is not subject to direct neutron activation because the water does not pass directly through the reactor cores. This water is discharged through different waterways, depending on the reactor. $K$ and $L$ Reactors use Savannah River water as a heat exchanger coolant. The $K$ Reactor heat-exchanger cooling water discharges to Pen Branch. The L Reactor heat-exchanger cooling water discharges to $L$ Lake, which overflows to Steel Creek. The heat-exchanger cooling water from P Reactor is returned to Par Pond, some of which overflows to Lower Three Runs Creek (Figure 3.1).

Radioactive (primarily tritium) and nonradioctive chemicals have been released into the ground water from seepage and chemical waste storage basins, and from their outfalls. The hydrogeologic profile at the SRS causes portions of these releases to enter the Savannah River, either directly from the ground water or by way of the onsite streams that drain into the river.

Effluent wastewater treatment plants are expected to deionize, filter and monitor the liquid effluents from operations at SRS. Tritium would not be removed by these processes. Trace amounts of other radionuclides are also expected to be released. Under current operational plans, the releases are expected to go to the Savannah River by way of Penn Branch.

\subsubsection{Current Status}

All five reactors were inoperative in 1989. Three reactors operated in 1988: K Reactor operated from January 1 to April 10, 1988; P Reactor operated from January to April, and 10 days in August; $L$ 
Reactor operated from January 1 to late June 1988. A fourth reactor, C Reactor, operated until 1986, when it was shut down for repairs. The fifth reactor, $R$ Reactor, was permanently shut down in 1964. Although the USDOE recently proposed the continued use of $K, L$ and $P$ Reactors for defense and nondefence purposes (pp. v-vi, USDOE, 1990), current plans are to operate K Reactor only (Todd V. Crawtord, personal communication).

\subsubsection{Scenarios and Empirical Models}

This assessment was performed for two major receptors that draw domestic raw water from the Savannah River approximately 80 miles $(129 \mathrm{~km})$ downstream from the SRS (Figure 3.2). These sites are the Port Wentworth (= Cherokee Hill), SC and Beaufort-Jasper, GA Water Treatment Plants. Risk assessments were performed from 1992, the year of planned resumption of operation of $K$ Reactor. A Final Environmental Impact Statement for continued operations at the SRS (USDOE, 1990) describes three possible scenarios:

1. Continued shutdown of all reactors;

2. Tritium-containing liquid waste streams are released to both seepage basins and to suriace waters;

3. Liquid wastes containing tritium will be released only into surface waters.

These three scenarios (Scenario 1, Scenario 2, Scenario 3) were modelled in this risk assessment study. Currently, resumption of operations is planned only for K Reactor under Scenario 3 (Todd V. Crawford, personal communication). Risk assessment of future operations of $K$ Reactor under Scenario 2 was performed solely for the purpose of demonstrating the effects of partially-directing tritium waste effluents into surface waters by way of ground water. Specific details for assumed full-operation of K Reactor, beginning in 1992, as they were applied to the six general steps outlined in section 5.1 are described below.

Based on information from previous reactor operations (DOE, 1990), an empirical model was used to predict the source term (the expected total Ci/yr released to surface waters from the SRS). Such a model was used because there was a large amount of data available to relate operations to resulting concentrations in the river. Tritium concentrations $(\mathrm{pCi} / \mathrm{L})$ in the river were estimated by dividing the source term by a distribution of annual Savannah River water volumes derived from 1954-1989 measurements (Table 5.1). Annual exposures of individuals to tritium ( $\mathrm{pCi} / \mathrm{yr}$ ) were estimated by calculating the intake of tritiated water through a variety of exposure pathways.

\subsubsection{Source Term Development}

The first problem to be considered for development of source terms for all scenarios was the prediction of future impacts on the Savannah River of tritium previously released to seepage and waste-storage basins. The existing data (Murphy et al., 1991) historically relate different types of SRS releases with annual quantities of tritium in the Savannah River (Table 5.1, Figure 5.1).

The annual fractional change relationships in Table 5.2 (column 3) were used to predict discharges from groundwater migration (Table 5.2, Figure 5.1) and resultant concentrations of tritium in the Savannah River. This model provides all of the source terms for $\mathrm{Ci}$ of tritium released into the SRS streams under Scenario 1 (and it contributes to the source terms for Scenarios 2 and 3 ). 
The data in Table 5.1 reveals that from 1980 onwards the average migration of tritium from seepage basins takes approximately 10 years to reach streams on the SRS (Figure 5.1a). The major portion of total tritiated-liquid waste release to the streams since 1980 has been by migration from the seepage basins. This is especially true after August 1988 because reactor operations ceased at that time.

Table 5.1. Annual Tritium Releases to Surface Waters at The SRS (derived from Murphy et al., 1991).

\begin{tabular}{|c|c|c|c|c|c|}
\hline Year & $\begin{array}{c}\text { Total }^{3} \mathrm{H} \\
\text { Released }\end{array}$ & $\begin{array}{c}\text { Releases } \\
\text { To } \\
\text { Streams } \\
\text { From } \\
\text { Processes } \\
\text { (Cityr) }\end{array}$ & $\begin{array}{l}\text { To } \\
\text { Streams } \\
\text { From } \\
\text { Ground } \\
\text { Water } \\
\text { (Cilyr) }\end{array}$ & $\begin{array}{c}\text { Fraction } \\
\text { of } 3 \mathrm{H} \\
\text { Vie } \\
\text { Ground } \\
\text { Water }\end{array}$ & $\begin{array}{c}\text { Savannah } \\
\text { River } \\
\text { Flow Rate }\end{array}$ \\
\hline 1954 & $3.66 E+02$ & $3.66 \mathrm{E}+02$ & $0.00 E+00$ & 0.00 & $7.16 E+12$ \\
\hline 1955 & $5.87 E+03$ & $5.87 E+03$ & $0.00 E+00$ & 0.00 & $5.39 E+12$ \\
\hline 1956 & $9.39 E+03$ & $9.39 E+03$ & $0.00 E+00$ & 0.00 & $5.30 E+12$ \\
\hline 1957 & $1.50 E+04$ & $1.50 E+04$ & $0.00 \mathrm{E}+00$ & 0.00 & $6.46 E+12$ \\
\hline 1958 & $2.44 E+04$ & $2.40 E+04$ & $4.00 E+02$ & 0.02 & $1.12 E+13$ \\
\hline 1959 & $4.20 E+04$ & $4.12 E+04$ & $8.00 E+02$ & 0.02 & $7.00 E+12$ \\
\hline 1960. & $6.40 E+04$ & $4.69 E+04$ & $1.60 \mathrm{E}+03$ & 0.03 & $1.22 E+13$ \\
\hline 1961 & $6.90 E+04$ & $5.38 E+04$ & $2.00 E+03$ & 0.03 & $8.72 E+12$ \\
\hline 1962 & $5.80 E+04$ & $4.67 E+04$ & $1.70 E+03$ & 0.03 & $9.11 E+12$ \\
\hline 1963 & $9.70 E+04$ & $7.47 E+04$ & $2.70 E+03$ & 0.03 & $9.38 E+12$ \\
\hline 1964 & $1.11 E+05$ & $8.07 E+04$ & $4.70 E+03$ & 0.04 & $1.63 E+13$ \\
\hline 1965 & $1.08 E+05$ & $9.84 E+04$ & $5.60 E+03$ & 0.05 & $1.27 E+13$ \\
\hline 1968 & $8.49 E+04$ & $7.73 E+04$ & $4.60 E+03$ & 0.05 & $9.34 E+12$ \\
\hline 1967 & $7.06 E+04$ & $6.40 E+04$ & $5.60 E+03$ & 0.08 & $8.22 E+12$ \\
\hline 1968 & $6.38 E+04$ & $5.58 E+04$ & $5.79 E+03$ & 0.09 & $8.88 E+12$ \\
\hline 1969 & $6.46 E+04$ & $4.54 E+04$ & $1.88 E+04$ & 0.29 & $9.64 E+12$ \\
\hline 1970 & $3.69 E+04$ & $2.39 E+04$ & $1.29 E+04$ & 0.35 & $6.91 E+12$ \\
\hline 1971 & $3.82 E+04$ & $2.02 E+04$ & $1.78 E+04$ & 0.47 & $8.51 E+12$ \\
\hline 1972 & $4.68 E+04$ & $2.88 E+04$ & $1.72 E+04$ & 0.37 & $1.01 \mathrm{E}+13$ \\
\hline 1973 & $7.11 E+04$ & $4.30 E+04$ & $2.78 E+04$ & 0.39 & $1.30 E+13$ \\
\hline 1974 & $5.99 E+04$ & $3.29 E+04$ & $2.71 E+04$ & 0.45 & $9.65 E+12$ \\
\hline 1975 & $5.56 E+04$ & $2.81 E+04$ & $2.75 E+04$ & 0.49 & $1.20 E+13$ \\
\hline 1976 & $5.96 E+04$ & $3.17 E+04$ & $2.79 E+04$ & 0.47 & $1.19 E+13$ \\
\hline 1977 & $4.38 E+04$ & $2.72 E+04$ & $1.66 E+04$ & 0.38 & $1.08 \mathrm{E}+13$ \\
\hline 1978 & $3.76 E+04$ & $2.72 E+04$ & $2.04 E+04$ & 0.54 & $1.01 E+13$ \\
\hline 1979 & $2.94 E+04$ & $1.01 E+04$ & $1.93 E+04$ & 0.66 & $1.06 E+13$ \\
\hline 1980 & $2.47 E+04$ & $1.03 E+04$ & $1.44 E+04$ & 0.58 & $1.23 E+13$ \\
\hline 1981 & $2.38 E+04$ & $9.60 E+03$ & $1.42 E+04$ & 0.60 & $6.17 E+12$ \\
\hline 1982 & $3.25 E+04$ & $1.10 E+04$ & $2.15 E+04$ & 0.66 & $6.80 E+12$ \\
\hline 1983 & $3.42 E+04$ & $1.42 E+04$ & $1.98 E+04$ & 0.58 & $1.09 E+13$ \\
\hline 1984 & $3.28 E+04$ & $1.05 E+04$ & $2.23 E+04$ & 0.68 & $1.12 E+13$ \\
\hline 1985 & $2.50 E+04$ & $6.10 E+03$ & $1.89 E+04$ & 0.76 & $6.31 E+12$ \\
\hline 1986 & $2.78 E+04$ & $7.33 E+03$ & $2.05 E+04$ & 0.74 & $6.11 E+12$ \\
\hline 1987 & 2.26E+04 & $4.32 E+03$ & $1.83 E+04$ & 0.81 & $1.01 E+13$ \\
\hline 1988 & $1.93 E+04$ & $5.44 E+03$ & $1.39 E+04$ & 0.72 & $5.06 E+12$ \\
\hline 1989 & $1.73 E+04$ & $3.64 E+03$ & $1 . \overline{37 E+04}$ & 0.79 & $6.99 E+12$ \\
\hline
\end{tabular}

Includes tritium released to groundwater that has not entered streams. 
Fractional changes in the total tritium releases to surface waters (streams) from 1979-1989 were used to predict discharges of tritiated groundwater from 1990-1999 (Table 5.2, Figure 5.1a). In the absence of releases of tritium to seepage basins after 1988, it was expected that discharges of tritium from groundwater to surface waters would decline continuously from 1996 rates. A linear model, based upon the previously predicted 1996-1999 values (Figure 5.1b insert), estimated seepage releases to streams from the year 2000 onwards. The model predicted that tritium migration to surface waters from previous releases to groundwater will reach negligible levels by the year 2004 (Table 5.2, Figure 5.1b). A linear model was used because of ignorance of both post1989 tritium releases and groundwater inventories. In the absence of information on groundwater inventories, we were also unable to generate decay corrected values for releases to surface waters.

Table 5.2. Predicted Annual Tritium Migration from Ground Water to Surface Waters at The SRS.

\begin{tabular}{|c|c|c|c|c|c|c|}
\hline Year & $\begin{array}{c}\text { Releases } \\
\text { To } \\
\text { Streams } \\
\text { From } \\
\text { Processes } \\
\text { (Cilyr) }\end{array}$ & $\begin{array}{l}\text { To } \\
\text { Streams } \\
\text { From } \\
\text { Ground } \\
\text { Water } \\
\text { (Ci/yr) }\end{array}$ & $\begin{array}{c}\text { Total } \\
3_{H} \\
\text { Released }\end{array}$ & $\begin{array}{c}\begin{array}{c}\Delta \text { from } \\
\text { Previous } \\
\text { year }\end{array} \\
\leftarrow\end{array}$ & Year & $\begin{array}{c}\text { Predicteda } \\
\text { Migration } \\
\text { Via } \\
\text { Ground } \\
\text { 'Nater } \\
\text { (Ci/yr) }\end{array}$ \\
\hline 1979 & $1.01 E+04$ & $1.93 E+04$ & $2.94 E+04$ & & 1989 & $1.37 E+04$ \\
\hline 1980 & $1.03 E+04$ & $1.44 E+04$ & $2.47 E+04$ & -0.16 & 1990 & $1.15 E+04$ \\
\hline 1981 & $9.60 E+03$ & $1.42 E+04$ & $2.38 E+04$ & -0.04 & 1991 & $1.10 E+04$ \\
\hline 1982 & $1.10 E+04$ & $2.15 E+04$ & $3.25 E+04$ & 0.37 & 1992 & $1.51 E+04$ \\
\hline 1983 & $1.42 E+04$ & $1.98 E+04$ & $3.42 E+04$ & 0.05 & 1993 & $1.59 E+04$ \\
\hline 1984 & $1.05 E+04$ & $2.23 E+04$ & $3.28 E+04$ & .0 .04 & 1994 & $1.53 E+04$ \\
\hline 1985 & $6.10 E+03$ & $1.89 E+04$ & $2.50 E+04$ & -0.24 & 1995 & $1.16 E+04$ \\
\hline 1986 & $7.33 E+03$ & $2.05 E+04$ & $2.78 E+04$ & 0.11 & 1996 & $1.29 E+04$ \\
\hline 1987 & $4.32 E+03$ & $1.83 E+04$ & $2.26 E+04$ & -0.19 & 1997 & $1.04 E+04$ \\
\hline 1988 & $5.44 E+03$ & $1.39 E+04$ & $1.93 E+04$ & -0.15 & 1998 & $8.86 E+03$ \\
\hline 1989 & $3.64 E+03$ & $1.37 E+04$ & $1.73 E+04$ & .0 .10 & 1999 & $7.98 E+03$ \\
\hline 1990 & & & & & 2000 & $6.00 E+03$ \\
\hline 1991 & & & & & 2001 & $4.37 E+03$ \\
\hline 1992 & & & & & 2002 & $2.74 E+03$ \\
\hline 1993 & & & & & 2003 & $1.11 E+03$ \\
\hline 1994 & & & & & 2004 & $0.00 E+00$ \\
\hline
\end{tabular}

Thus, the predicted groundwater discharges (Migrations in Table 5.2) have two components:

1. Groundwater discharges from 1990-1999 are based upon fractional changes in total releases from 1980-1989 (Figure 5.1a);

2. Groundwater discharges from 2000-2004 are an extension of a linear model developed from the predictions for 1996-1999 (Figure 5.1b). 
Figure 5.1a. Relationship of Total Releases of Tritium (1980-1989) to the Predicted Tritium Discharges to Surface Waters During the Next Ten Year Period (1990-1999).

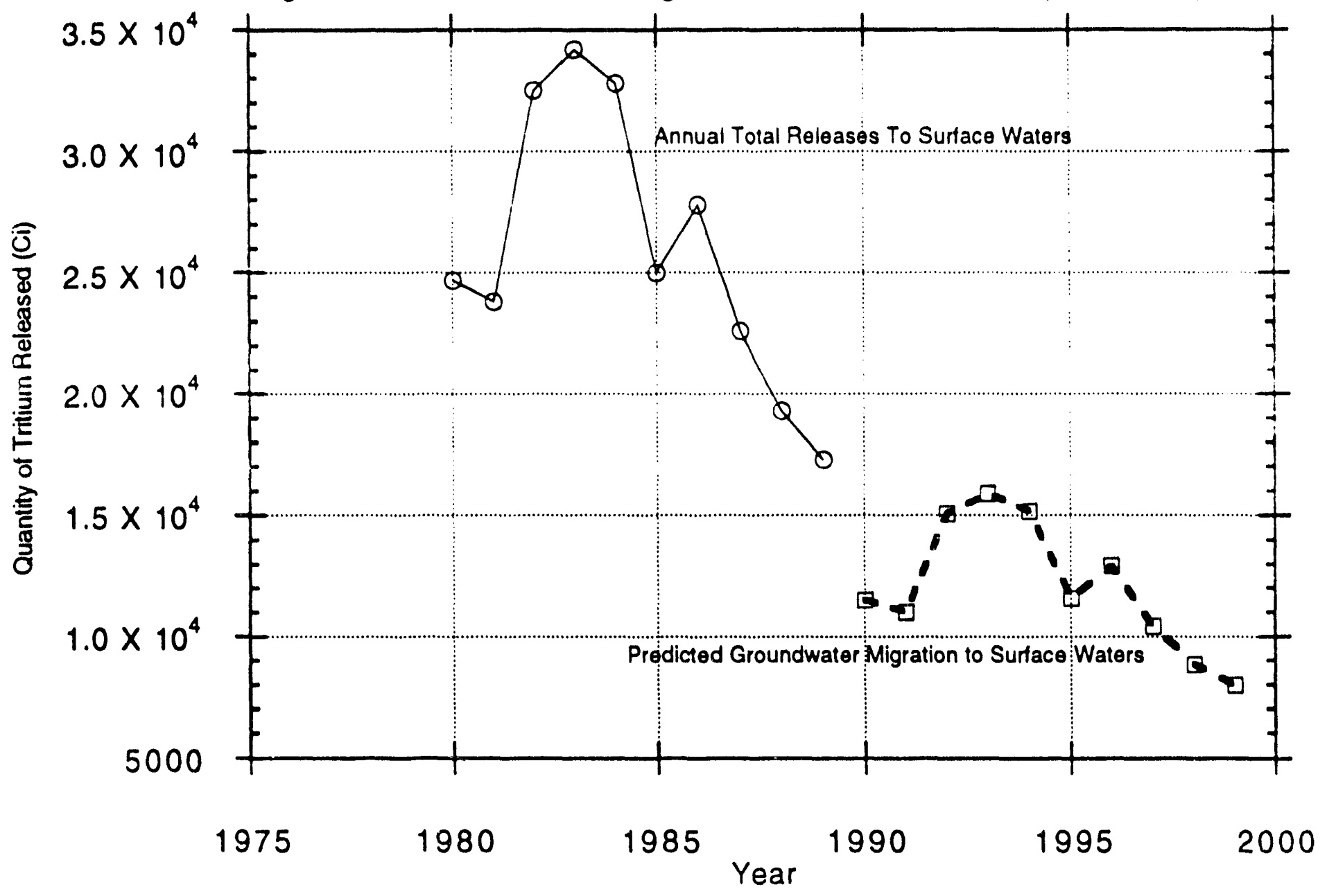


Figure 5.1b Linear Model for Predicting Tritium

Releases from Seepage to Surface Waters After 1999

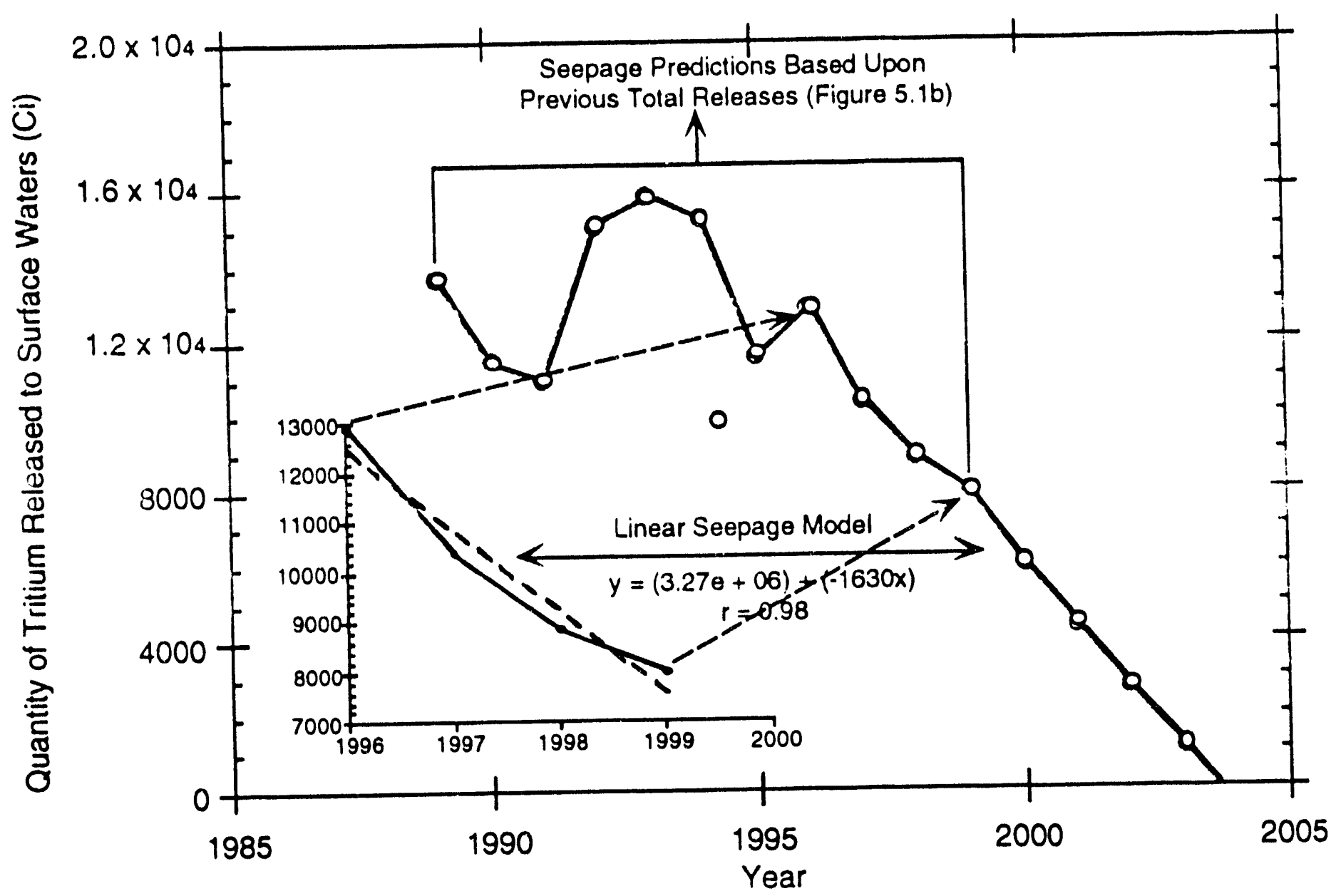

In Scenario 2, tritium releases from future SRS operations will go to surface waters directly from operations and by groundwater migration. For the years 1992-2003, the predicted migrations from ground water in Scenario 1 (Table 5.2) have to be added to the tritium releases from future operations to obtain the total curies discharged to surface waters (Table 5.3). Thereafter, only releases from future operations will contribute to total discharges of tritium to surface waters .

Table 4-7 in USDOE (1990) reports a total $1.16 \times 10^{4} \mathrm{Ci} / \mathrm{yr}$ of future operational tritium releases from $K, L$ and $P$ Reactors to surface streams. $K$ Reactor would contribute $71 \%$ of the releases:

$$
\left(1.16 \times 10^{4} \mathrm{Ci} / \mathrm{yr}\right) \times 0.71=8.24 \times 10^{3} \mathrm{Ci} / \mathrm{yr} .
$$

Table 2-3 in the same document indicates that $2780 \mathrm{Ci} / \mathrm{yr}$ would discharge into Indian Grave Branch, beginning six years after release of tritium from $\mathrm{K}$ Reactor to a seepage basin. During the first six years of $K$ Reactor operation (prior to 1998), in addition to migration from past operations (prior to 1989), the only tritium entering surface waters would be from direct operational releases:

$\left(8.24 \times 10^{3} \mathrm{Ci} / \mathrm{yr}\right) \cdot\left(2.78 \times 10^{3} \mathrm{Ci} / \mathrm{yr}\right)=5.46 \times 10^{3} \mathrm{Ci} / \mathrm{yr}$. 
Table 5.3. Predicted Discharges to Surface Waters from Past and Future Releases to Groundwater and Directly from Future Operations (Scenario 2).

\begin{tabular}{ccccc} 
Year & $\begin{array}{c}\text { Migrationa } \\
\text { to Streams } \\
\mathrm{Ci}\end{array}$ & $\begin{array}{c}\text { KSeepage } \\
\text { to Streams } \\
\mathrm{Ci}\end{array}$ & $\begin{array}{c}\text { Operations } \\
\text { to Streams } \\
\mathrm{Ci}\end{array}$ & $\begin{array}{c}\text { Total to } \\
\text { Streams } \\
\mathrm{Ci}\end{array}$ \\
\hline 1992 & $1.50 E+04$ & $0.00 E+00$ & $5.46 E+03$ & $2.05 E+04$ \\
1993 & $1.60 E+04$ & $0.00 E+00$ & $5.46 E+03$ & $2.15 E+04$ \\
1994 & $1.50 E+04$ & $0.00 E+00$ & $5.46 E+03$ & $2.05 E+04$ \\
1995 & $1.20 E+04$ & $0.00 E+00$ & $5.46 E+03$ & $1.75 E+04$ \\
1996 & $1.30 E+04$ & $0.00 E+00$ & $5.46 E+03$ & $1.85 E+04$ \\
1997 & $1.00 E+04$ & $0.00 E+00$ & $5.46 E+03$ & $1.55 E+04$ \\
1998 & $8.90 E+03$ & $2.78 E+03$ & $5.46 E+03$ & $1.71 E+04$ \\
1999 & $8.00 E+03$ & $2.78 E+03$ & $5.46 E+03$ & $1.62 E+04$ \\
2000 & $6.00 E+03$ & $2.78 E+03$ & $5.46 E+03$ & $1.42 E+04$ \\
2001 & $4.40 E+03$ & $2.78 E+03$ & $5.46 E+03$ & $1.26 E+04$ \\
2002 & $2.70 E+03$ & $2.78 E+03$ & $5.46 E+03$ & $1.09 E+04$ \\
2003 & $1.10 E+03$ & $2.78 E+03$ & $5.46 E+03$ & $9.34 E+03$ \\
2004 & $0.00 E+00$ & $2.78 E+03$ & $5.46 E+03$ & $8.24 E+03$ \\
\hline
\end{tabular}

a Migrations from past operational releases to basins

Table 5.4. Predicted Discharges to Surface Waters from Past Releases to Groundwater and from Future Operational Releases to Surface Waters Only (Scenario 3).

\begin{tabular}{|cccc|} 
Year & $\begin{array}{c}\text { Migrationa } \\
\text { to Streams } \\
\mathrm{Ci}\end{array}$ & $\begin{array}{c}\text { Operations } \\
\text { to streams } \\
\mathrm{Ci}\end{array}$ & $\begin{array}{c}\text { Total to } \\
\text { Streams } \\
\mathrm{Ci}\end{array}$ \\
\hline 1992 & $1.50 E+04$ & $1.40 E+04$ & $2.90 E+04$ \\
1993 & $1.60 E+04$ & $1.40 E+04$ & $3.00 E+04$ \\
1994 & $1.50 E+04$ & $1.40 E+04$ & $2.90 E+04$ \\
1995 & $1.20 E+04$ & $1.40 E+04$ & $2.60 E+04$ \\
1996 & $1.30 E+04$ & $1.40 E+04$ & $2.70 E+04$ \\
1997 & $1.00 E+04$ & $1.40 E+04$ & $2.40 E+04$ \\
1998 & $8.90 E+03$ & $1.40 E+04$ & $2.29 E+04$ \\
1999 & $8.00 E+03$ & $1.40 E+04$ & $2.20 E+04$ \\
2000 & $6.00 E+03$ & $1.40 E+04$ & $2.00 E+04$ \\
2001 & $4.40 E+03$ & $1.40 E+04$ & $1.84 E+04$ \\
2002 & $2.70 E+03$ & $1.40 E+04$ & $1.67 E+04$ \\
2003 & $1.10 E+03$ & $1.40 E+04$ & $1.51 E+04$ \\
2004 & $0.00 E+00$ & $1.40 E+04$ & $1.40 E+04$ \\
\hline
\end{tabular}

aMigrations from past operational releases to basins

In Scenario 3, all tritiumi released from future operations would go directly to surface waters after effluent treatment of liquid waste streams. Table 4-6 in DOE (1990) predicts combined discharges of tritium from K, L and P Reactors to seepage basins to total $1.21 \times 10^{4} \mathrm{CV} / \mathrm{yr}$. Under Scenario 3 , $71 \%$ of the discharges to seepage would be diverted and added to the previously calculated direct releases to surface waters from $\mathrm{K}$ Reactor: 


$$
\left(8.59 \times 10^{3} \mathrm{Ci} / \mathrm{yr}\right)+\left(5.46 \times 10^{3} \mathrm{Ci} / \mathrm{yr}\right)=1.41 \times 10^{4} \mathrm{CV} / \mathrm{yr}
$$

The total tritium released to surface waters in Scenario 3 would be the sum of migration from previous discharges to seepage (before 1989) and direct releases from operation of $\mathrm{K}$ Reactor beginning in 1992 (Table 5.4).

Under Scenarios 2 and 3, predicted source terms do not change after 2004, but would have 10 be modified for curtailment of operations, for operation of $L$ and/or $P$ Reactors, or for major accidents.

The next procedure converts the source terms to tritium concentrations in the Savannah River. Tritium concentrations are monitored just below the SRS at R-10 and at the two major receptor sites approximately 80 miles downstream from the SRS (Figure 5.2). R-10 is approximately 10 miles downstream from the entry of Lower Threemile Creek into the Savannah River. R-10 samples represent the highest concentrations of tritium in thoroughly mixed ground, tributary and Savannah River water (Murphy et al., 1990). Background tritium concentrations in the Savannah River are obtained from sampling site R-2 near the upstream border of the SRS (Figure 3.2). These background levels reflect deposition of tritium from atmospheric sources, such as atomic bomo testing. The net values (subtraction of R-2 concentrations from the downstream measurements) represent the contributions of tritium from the SRS to the Savannah River.

In the current analysis, net concentrations are predicted without accounting for background concentrations, by directly using the predicted annual releases of tritium from the SRS. Table 5.1 provides the data on annual volumes of flow in the river. The data from 1954-1989, ranging from $5.1 \times 10^{12} \mathrm{~L}$ to $16.3 \times 10^{12} \mathrm{~L}$ yield a normal distribution of annual flows, with an arithmetic mean of $9.3 \times 10^{12} \mathrm{~L}\left(\mathrm{SD}=2.6 \times 10^{12} \mathrm{~L}\right)$. Dividing each predicted total annual SRS tritium release by samples from the distribution of annual river flow volumes yields distributions of net titium concentrations at R-10, each year, in each scenario:

$$
\left[{ }^{3} H\right]_{R-10}=\frac{{ }^{3} H \times 10^{12}}{V}
$$

where;

$\left[{ }^{3} \mathrm{H}\right]_{\mathrm{R}-10}=$ concentration of tritium ( $\left.\mathrm{pCi} / \mathrm{L}\right)$

${ }^{3} \mathrm{H}=$ tritium release (Ci/yr from either table $5.4,5.5$ or 5.6 )

$10^{12}=$ conversion factor $(\mathrm{pCi} / \mathrm{Ci})$

$V=$ normal distribution of annual water volumes (Lyr).

The contributions of SRS releases to the average concentrations of tritium at R-10 (beginning in 1992) are summarized for the three scenarios in Table 5.5 in the following section.

\subsection{Transport}

Two major receptor sites draw raw water supplies from the Savannah River approximately 80 miles $(129 \mathrm{~km}$ ) downstream from the SAS (Fig. 3.2). These sites are the Port Wentworth (= Cherokee Hill), SC and Beaufort-Jasper, GA Water Treatment Plants. Tritium concentrations are lower at the two receptor sites than at R-10 because of the interacting effects of further dilution of tritiated water and evaporation of tritiated water during the downstream course of the river. 
Table 5.5. Annual Averages of Measured Concentrations ( $\mathrm{pC} / \mathrm{L} / \mathrm{L}$ ) of Tritium in the Savannah Rivera

\begin{tabular}{|c|c|c|c|}
\hline $\begin{array}{l}\text { Year } \\
1985 \\
1986 \\
1987 \\
1988 \\
1989\end{array}$ & $\begin{array}{c}\text { Highway } 301 \\
(R-10) \\
3.7 E+3 \\
3.9 E+3 \\
3.3 E+3 \\
3.4 E+3 \\
2.9 E+3\end{array}$ & $\begin{array}{c}\text { Beaufort-Jasper } \\
\text { (raw) } \\
2.9 E+3 \\
3.1 E+3 \\
2.2 E+3 \\
2.6 E+3 \\
2.3 E+3\end{array}$ & $\begin{array}{c}\text { Port Wentworth } \\
\text { (raw) } \\
3.0 E+3 \\
3.4 E+3 \\
2.3 E+3 \\
2.5 E+3 \\
2.3 E+3\end{array}$ \\
\hline
\end{tabular}

aCummins et al., 1990; Davis et al., 1989, Mikol et al., 1988;

Zeigler et al., 1987.

Since 1985, the measured conrentrations of tritium in the water at the two receptor sites have been approximately the same (Taible 5.5; DOE, 1990). The expected concentrations of tritium at the receptor sites and associated uncertainties for each Scenario can be estimated by multiplying for each year from 1992-2004 samples from a normal distribution of $\left[{ }^{3} \mathrm{H}\right.$ ] at R-10 (calculated by use of equation 5 above) by samples from a normal distribution of the 1985-1989 ratios of $[3 \mathrm{H}]_{\text {receptors }}$ io $\left[{ }^{3} \mathrm{H}\right]_{\mathrm{R}-10}$. The expected concentrations of tritium at the receptor sites (beginning in 1992) for the three scenarios are reported in Table 5.6.

$$
\left[{ }^{3} \mathrm{H}\right]_{\text {receptors }}=\left[{ }^{3} \mathrm{H}\right]_{\mathrm{R}-10} \times \mathrm{r}
$$

where:

$r=\frac{\left[{ }^{3} H\right]_{\text {receptors }}}{\left[{ }^{3} H\right]_{R-10}} \quad(1985-1989$, normally distributed, average, $0.701 ; \mathrm{SD}, 0.156 ;$ range $0.42-('), 92)$

Table 5.6. Predicted Average Concentrations of Tritium in the Savannah River.

\begin{tabular}{|c|c|c|c|c|c|c|}
\hline & Scenari & 1 & Scenari & 2 & Scenaric & \\
\hline Year & $\begin{array}{c}{[3 \mathrm{H}] \mathrm{R}-10^{\mathrm{a}}} \\
\mathrm{pCil}\end{array}$ & $\begin{array}{c}{[3 \mathrm{H}]_{\text {receptor }}} \\
\text { pCin }\end{array}$ & $\begin{array}{c}{[3 \mathrm{H}] \mathrm{R}-10^{\mathrm{a}}} \\
\quad \mathrm{PCVL}\end{array}$ & $\begin{array}{c}{[3 \mathrm{H}]_{\text {receptor }} \text { b }} \\
\text { pCil }\end{array}$ & $\begin{array}{c}{[3 \mathrm{H}] \mathrm{R}-10^{a}} \\
\mathrm{pCi} / \mathrm{L}\end{array}$ & $\begin{array}{c}{[3 \mathrm{H}] \text { receptor }^{b}} \\
\text { pCi/L }\end{array}$ \\
\hline 1992 & $1.62 E+03$ & $1.14 E+03$ & $2.21 E+03$ & $1.55 E+03$ & $3.14 E+03$ & $2.20 E+03$ \\
\hline 1993 & $1.73 E+03$ & $1.21 E+03$ & $2.32 E+03$ & $1.62 E+03$ & $3.24 E+03$ & $2.27 E+03$ \\
\hline 1994 & $1.62 E+03$ & $1.14 E+03$ & $2.21 E+03$ & $1.55 E+03$ & $3.14 E+03$ & $2.20 E+03$ \\
\hline 1995 & $1.30 E+03$ & $9.08 E+02$ & $1.89 E+03$ & $1.32 E+03$ & $2.81 E+03$ & $1.97 E+03$ \\
\hline 1996 & $1.40 E+03$ & $9.84 E+02$ & $1.99 E+03$ & $1.40 E+03$ & $2.92 E+03$ & $2.05 E+03$ \\
\hline 1997 & $1.08 E+03$ & 7.57E+02 & $1.67 E+03$ & $1.17 E+03$ & $2.60 E+03$ & $1.82 E+03$ \\
\hline 1998 & $9.61 E+02$ & $6.74 E+02$ & $1.85 E+03$ & $1.30 E+03$ & $2.48 E+03$ & $1.74 E+03$ \\
\hline 1999 & $8.64 E+02$ & $6.06 E+02$ & $1.75 E+03$ & $1.23 E+03$ & $2.38 E+03$ & $1.67 E+03$ \\
\hline 2000 & $6.48 E+02$ & $4.54 E+02$ & $1.54 E+03$ & $1.08 E+03$ & $2.16 E+03$ & $1.52 E+03$ \\
\hline 2001 & $4.75 E+02$ & $3.33 E+02$ & $1.36 E$ & $9.57 E+02$ & $1.99 E+03$ & $1.40 E+03$ \\
\hline 2002 & $2.92 E+02$ & $2.04 E+02$ & $1.18 E+03$ & $8.28 E+02$ & $1.81 E+03$ & $1.27 E+03$ \\
\hline & $1.19 E+02$ & $8.33 E+01$ & $1.01 F+03$ & $7.07 E+02$ & $1.64 E+03$ & $1.15 E+03$ \\
\hline 2004 & $0.00 E+00$ & $0.00 E+00$ & $8.89 E+02$ & $6.23 E+02$ & $1.52 E+03$ & $1.06 E+03$ \\
\hline
\end{tabular}

aTen miles downstream from the SRS

bReceptor is Port Wentworth, SC or Beaufort-Jasper, GA 
Table 5.7. Factors for Calculating Exposures to Tritium in Water Taken from the Savannah River.

$\begin{array}{lllll}\text { Pathway Factor (symbol) Units } & \text { Arithmetic Distribution' } & \text { Source }\end{array}$

\begin{tabular}{|c|c|c|c|c|c|}
\hline & Bodv Weiaht (BW) & $\mathrm{ka}$ & $58 \mathrm{E}+01$ & (SD 14) loanormal & $a$ \\
\hline & Surface Area (SA) & $m^{2}$ & $1.5 E+00$ & (SD 0.24) lognormal & $a$ \\
\hline & Breathing rate (BR) & $\mathrm{m}^{3} / \mathrm{kg}-\mathrm{d}$ & $4.0 E-01$ & (SD 0.5) lognormal & $b$ \\
\hline \multirow[t]{2}{*}{ Ingestion } & Water Ingestion (WI) & L/yr & $3.4 E+02$ & (SD 105) lognormal & c \\
\hline & Fish Ingestion (Fi) & $\mathrm{kg} / \mathrm{yr}$ & $7.7 E+00$ & (SD 2.84) lognormal & $c$ \\
\hline \multicolumn{6}{|l|}{ Dermal } \\
\hline & $\begin{array}{c}\text { Dermal permeability for } 3 \mathrm{H} \\
(\mathrm{Kp})\end{array}$ & m/hr & $1.5 E-05$ & (0.5 to 2.5$)$ uniform & d \\
\hline & SAVBW & $\mathrm{m}^{2} / \mathrm{kg}$ & $2.7 E-02$ & (0.0025) lognormal & $b$ \\
\hline & Showers & $d / y r$ & $3.7 E+02$ & & $e$ \\
\hline & Fraction of surface area (Fsa) & $\mathrm{m}^{2} / \mathrm{cm}$ & $6.5 \mathrm{E}-01$ & $(0.4-0.9)$ uniform & $\bar{b}$ \\
\hline & Duration in shower (Ds) & $\mathrm{hr} / \mathrm{d}$ & $1.3 E-01$ & (SD 0.085) legnormal & $b$ \\
\hline & Duration in bathroom (Db) & $\mathrm{hr} / \mathrm{d}$ & $3.3 E-01$ & (SD 0.22) lognormal & $b$ \\
\hline & Duration in house (Dh) & $\mathrm{hr} / \mathrm{d}$ & $1.4 E+01$ & $(8-20)$ uniform & $b$ \\
\hline & Duration swimming (Dswim) & (hr/yr) & $8.9 E+00$ & $\begin{array}{l}\text { (SD 1.4, maximum } \\
\text { 13.1) lognormal }\end{array}$ & $\bar{c}$ \\
\hline & Conversion factor (volume) & $\cup \mathrm{m}^{3}$ & $1.0 E+03$ & & \\
\hline \multicolumn{6}{|l|}{ Inhalation } \\
\hline & Water Use: shower (Ws) & L/hr & $4.8 E+02$ & (SD 160) lognormal & $\mathrm{b}$ \\
\hline & $\begin{array}{c}\text { Water Use: bathroom \& } \\
\text { house }(W b, h)\end{array}$ & L/hr & $4.2 E+01$ & (SD 15) lognormal & $\mathrm{b}$ \\
\hline & $\begin{array}{c}\text { Ventilation Rate: shower } \\
\text { (VRs) }\end{array}$ & $m^{3} / \mathrm{hr}$ & $1.2 E+01$ & (4-20) uniform & $b$ \\
\hline & $\begin{array}{c}\text { Ventilation Rate: bathroom } \\
\text { (NRb) }\end{array}$ & $\mathrm{m}^{3} / \mathrm{hr}$ & $5.4 E+01$ & $(10-100)$ uniform & $\mathrm{b}$ \\
\hline & $\begin{array}{c}\text { Ventilation Rate: house } \\
\text { (VRh) }\end{array}$ & $\mathrm{m}^{3} / \mathrm{hr}$ & $7.5 E+02$ & $(300-1200)$ uniform & $\mathrm{b}$ \\
\hline & $\begin{array}{l}\text { Transfer Efficiency }\left(\varnothing_{\mathrm{Bn}}\right) \text { : } \\
\text { shower + bath } \\
\text { house }\end{array}$ & & $\begin{array}{l}7.0 \mathrm{E}-01 \\
5.4 \mathrm{E}-01\end{array}$ & & $a, b$ \\
\hline & $\begin{array}{l}\text { HTO Diffusion in water } \\
\text { (DRw) }\end{array}$ & $\mathrm{m}^{2} / \mathrm{s}$ & 1.9E-09 & & 1 \\
\hline & HTO Diffusion in air (DRa) & $\mathrm{m}^{2 / \mathrm{s}}$ & 2.4E-05 & & $g$ \\
\hline & RT/H & $\begin{array}{l}\text { amol/m }{ }^{3} \mathrm{HOH} \\
\text { gmoVm }{ }^{3} \text { air }\end{array}$ & $4.5 E+04$ & $\begin{array}{l}\text { gas constant } x 293^{\circ} \mathrm{K} \\
\text { Henry': s law constant }\end{array}$ & $a, b$ \\
\hline & $\begin{array}{l}\text { Transfe, Efficiency }\left(\sigma_{3 \mathrm{H}}\right) \text { : } \\
\text { shower + bath } \\
(0.70 \cdot 0.036) \\
\text { house } \\
(0.54 \cdot 0.036)\end{array}$ & $\frac{\oslash_{R n} \times 2 E+6}{\left[\left(\frac{2.5}{\left(D R_{w}\right)^{\frac{2}{3}}}\right)+\left(\frac{R T}{H\left(D R_{a}\right)^{\frac{2}{3}}}\right)\right.}$ & $\begin{array}{l}2.5 E-02 \\
1.9 E-03\end{array}$ & & $a, b$ \\
\hline
\end{tabular}

1 (SD = standard deviation, or range) type of distribution

a McKone and Daniels, 1991

d Bronaugh, 1986

b McKone and Bogen, 1992

Q US EPA, 1990

c Taken or derived from Hamby, 1991, 1992

I NCRP, 1972

g CRC, 1986 


\subsection{Exposures}

Exposure pathways for tritium in surface water are determined on the basis of Savannah River water utilization. The pathways for domestic and recreational exposures include: Ingestion (water, fish); inhalation of water vapor (shower, bathroom and house); and dermal exposure (shower and swimming). Pathway exposure factors (PEFs) are terms that translate unit concentrations in media (e.g., pCi/L) into exposures per unit time (e.g., pCi/yr). PEFs use information on human physiology and behavior, and environmental transport for specific media (McKone, 1990). The PEFs in this investigation were either taken or derived from Hamby (1991, 1992), or calculated on an annual basis by modifying the PEFs derived from relevant published chronic daily intake values (McKone and Bogen, 1992; McKone and Daniels, 1991). Where there was a choice, Hamby's (1991, 1992) values receive preference because they specifically used regional surveys of the Southeastern United States. Thus, they should be most pertinent for an analysis of the SRS. Relevant human anatomical properties (Table 5.7), as combined for children and adults (McKone and Daniels, 1991), were also used in the calculations. Since tritiated water is uniformly distributed throughout the body water, whole-body radiation exposures in $\mathrm{pCi} \bullet\left(\mathrm{kg}^{\bullet} \mathrm{y}\right)^{-1}$ were used in place of chemical exposures $\left(\mathrm{mg}^{\bullet}\left(\mathrm{kg}^{\bullet} \mathrm{y}\right)^{-1}\right)$ in the calculations of McKone and Bogen (1992). The calculated results from each pathway were added together to obtain annual total whole-body exposures.

\subsubsection{Exposure Pathways}

\section{Ingestion}

Distributions of annual ingestion of water and fish were derived from consumption rates reported by Hamby $(1991,1992)$. Hamby's values for drinking water consumption were obtained from NRC (1977) default values, and his consumption rates for fish were derived from data for individuals living in the South, collected in a 1977-1978 survey by the U.S. Department of Agriculture (1983).

Annual water ingestion (WI) was calculated as combined annual water ingestion (L•yr $\left.{ }^{-1}\right)$ derived by weighting Hamby's (1991) consumption rates for adults and nonadults (Table 5.8).

Table 5.8. Annual Water Ingestion $\left(L \cdot y r^{-1}\right)^{a}$

\begin{tabular}{|c|c|c|c|c|c|}
\hline $\begin{array}{l}\text { Period } \\
\text { (years) } \rightarrow\end{array}$ & $\begin{array}{l}\text { Adult } \\
51\end{array}$ & $\begin{array}{c}\text { Teenager } \\
7\end{array}$ & $\begin{array}{c}\text { Child } \\
11\end{array}$ & $\begin{array}{c}\text { Infant } \\
1 \\
\end{array}$ & $\begin{array}{c}\text { Arithmetic } \\
\text { Meanc } \\
70\end{array}$ \\
\hline $\begin{array}{l}\text { Factorb } \\
\text { Average }^{c} \\
\text { Maximumc }^{c}\end{array}$ & $\begin{array}{l}0.73 \\
370 \\
730\end{array}$ & $\begin{array}{l}0.10 \\
260 \\
510\end{array}$ & $\begin{array}{l}0.16 \\
260 \\
510\end{array}$ & $\begin{array}{l}0.01 \\
260 \\
330\end{array}$ & $\begin{array}{l}340 \\
654\end{array}$ \\
\hline
\end{tabular}

aData from Hamby (1991).

bFractions of a 70 yr lifetime.

$c^{\prime}(0.73 \times$ Adult $)+(0.10 \times$ Teenager $)+(0.16 \times$ Child $)+(0.01 \times$ Infant $)$. Individual values (NRC, 1977) are arithmetic. 
A standard deviation $(\sigma)$ for the lifetime average was approximated by using the following relationship (derived from Hamby, 1991):

$$
\begin{aligned}
& \text { Maximum } \approx \text { Average }+3 \sigma \\
& \sigma \approx \frac{\text { Maximum-Average }}{3}
\end{aligned}
$$

Substitution of the values from Table 5.9:

$$
\sigma=\frac{\frac{654 L}{y r}-\frac{340 L}{y r}}{3}=\frac{105 L}{y r}
$$

The distribution of age-weighted WI was assumed to be lognormal (Table 5.7). Water ingestion exposure (WIE) to tritium was calculated by the expression

$$
W I E=W I(U / y r) \times\left[{ }^{3} H\right]_{r e c e p t o r ~}(p C i / L)=p C i / y r
$$

The Savannah River is closed indefinitely to shellfish harvesting (Hamby, 1991). Therefore, only finfish consumption was considered in this assessment. Annual ingestion of the edible portion of

\begin{tabular}{|c|c|c|c|c|c|}
\hline $\begin{array}{l}\text { Period } \\
\text { (years) } \rightarrow\end{array}$ & $\begin{array}{c}\text { Adult } \\
51 \\
\end{array}$ & $\begin{array}{c}\text { Teenager } \\
7\end{array}$ & $\begin{array}{c}\text { Child } \\
11 \\
\end{array}$ & $\begin{array}{c}\text { Infant } \\
1\end{array}$ & $\begin{array}{c}\text { Arithmetic } \\
\text { Meanc } \\
70\end{array}$ \\
\hline $\begin{array}{l}\text { Factorb } \\
\text { Averagec } \\
\text { Maximumc }\end{array}$ & $\begin{array}{c}0.73 \\
9 \\
19\end{array}$ & $\begin{array}{l}0.10 \\
6.9 \\
14\end{array}$ & $\begin{array}{c}0.16 \\
3.0 \\
6\end{array}$ & $\begin{array}{c}0.01 \\
- \\
-\end{array}$ & $\begin{array}{r}7.7 \\
16.2\end{array}$ \\
\hline
\end{tabular}
finfish (FI) was calculated as combined annual finfish ingestion $\left(\mathrm{kg}^{\circ} \mathrm{yr}^{-1}\right)$ derived by weighting Hamby's (1991) consumption rates for adults and nonadults (Table 5.9).

Table 5.9. Annual Finfish Ingestion (kgør $\left.{ }^{-1}\right)^{a}$

A standard deviation $(\sigma)$ for the lifetime average was approximated by substituting the values from Table 6.7 into formula (8),

$$
\sigma \approx \frac{\frac{16.2 \mathrm{~kg}}{y r}-\frac{7.7 \mathrm{~kg}}{y r}}{3}=\frac{2.8 \mathrm{~kg}}{y r}
$$

The distribution of age-weighted $\mathrm{FI}$ was assumed to be lognormal (Table 5.7). 
On average, less than $10 \%$ of the fish consumed in the United States is taken from freshwater (NCRP 52, 1977). This percentage appears to be appropriate for the receptor populations in question because of their proximity to the Atlantic Ocean. An age weighted arithmetic mean fraction (Fr) of 0.09 was calculated from data for the Southeast (Rupp et al., 1980). A maximum Fr of 1.00 was assumed because of the possibility that a few people obtain all their fish from recreational freshwater fishing in the Savannah River. The distribution of $\mathrm{Fr}$ was assumed to be lognormal. A standard deviation $(\sigma)$ for the average fraction of ingestion of fish from fresh water is approximated by substituting an arithmetic average of 0.1 and a maximum of 1.00 into formula (8),

$$
\sigma \approx \frac{1.0-0.1}{3}=0.3
$$

Values from the distribution of $\mathrm{Fr}$ were multiplied by values from a lognormal distribution of $\mathrm{Fl}$ (Table 5.7) to obtain a lognormal distribution of $\mathrm{kg}^{\circ} \mathrm{rr}^{1}$ ingested freshwater finfish (FFI) with the following estimated parameters: arithmetic average, $0.53 ; \sigma, 5.6 \mathrm{E}-4$; maximum, 12.0.

$$
F F I=(F r) \times F l\left(k g \bullet y r^{-1}\right)=k g \circ y r^{-1}
$$

Fish ingestion exposure (FIE) was calculated by using the expression

$$
\mathrm{FIE}=\mathrm{FFI}\left(\mathrm{kg}^{\circ} \mathrm{yr} \mathrm{r}^{-1}\right) \times \mathrm{WF} \times\left[^{3} \mathrm{H}\right]_{\text {receptor }}\left(\mathrm{pCi} \cdot \mathrm{L}^{-1}\right)=\mathrm{pCi} \cdot \mathrm{yr}^{-1}
$$

$W F$ is the fraction of fish weight as body water $(=0.71$; Holmes and Donaldson, 1969). Tritiated water is freely exchangeable in fish and shellfish with ambient water and has approximately the same concentration in body water as in ambient water (Bruner, 1973; Harrison et al., 1973; Morgan et al., 1973). Substituting $1 \mathrm{~kg}$ for 1 liter of water:

$$
\mathrm{FIE}=\left(\mathrm{kg}^{\circ} \mathrm{yr} \mathrm{r}^{-1}\right) \times .71 \times\left[{ }^{3 \mathrm{H}}\right]\left(\mathrm{pCi} \odot \mathrm{kg}^{-1}\right)=\mathrm{pCi}^{\circ} \mathrm{yr} \mathrm{r}^{-1}
$$

\section{Inhalation Exposures}

There are three indoor compartments: shower; bathroom; and house. IEF is the inhalation exposure factor calculated for each of the compartments, using the formulas and distributions of exposure factors (Table 5.7) of McKone and coworkers (1991, 1992).

$$
I E F=\frac{W}{V R} \times \varnothing \times B R \times D \times B W \times \frac{1 d}{24 h r} \times \frac{365 d}{y r}
$$

where:

$W=$ water use in each compartment $\left(L \cdot h r^{-1}\right)$;

$V R=$ ventilation rate of each compartment $\left(\mathrm{m}^{3} \cdot \mathrm{hr}^{-1}\right)$;

$\emptyset=$ water transfer efficiency (Table 5.6);

$D=$ duration of exposure $(\mathrm{hr} / \mathrm{d})$;

$\mathrm{BR}=\mathrm{combined}$ breathing rate $\left(\mathrm{m}^{3} \cdot(\mathrm{kg} \cdot \mathrm{d})^{-1}\right)$;

$\mathrm{BW}=$ body weight $(\mathrm{kg})$. 
Substituting average values from table 5.7 yields the following results for the three pathways.

$$
\begin{aligned}
& \mathrm{IEF}_{\text {shower }}=\frac{480 \frac{\mathrm{L}}{\mathrm{hr}}}{12 \frac{\mathrm{m}^{3}}{\mathrm{hr}}} \times 0.025 \times \frac{0.4 \mathrm{~m}^{3}}{\mathrm{Kg} \bullet \mathrm{d}} \times \frac{0.13 \mathrm{hr}}{d} \times 58 \mathrm{~kg} \times \frac{1 \mathrm{~d}}{24 \mathrm{hr}} \times \frac{365 \mathrm{~d}}{y r}=45.87 \mathrm{~L} \mathrm{yr} \\
& \mathrm{IEF}_{\text {Bathroom }}=\frac{42 \frac{\mathrm{L}}{\mathrm{hr}}}{54 \frac{\mathrm{m}^{3}}{\mathrm{hr}}} \times 0.025 \times \frac{0.4 \mathrm{~m}^{3}}{\mathrm{Kg} \cdot \mathrm{d}} \times \frac{0.33 \mathrm{hr}}{d} \times 58 \mathrm{~kg} \times \frac{1 \mathrm{~d}}{24 \mathrm{hr}} \times \frac{365 \mathrm{~d}}{y r}=2.26 \mathrm{~L} \mathrm{yr} \\
& \mathrm{IEF}_{\text {house }}=\frac{42 \frac{\mathrm{L}}{\mathrm{hr}}}{750 \frac{\mathrm{m}^{3}}{\mathrm{hr}}} \times 1.9 \times 10^{-3} \times \frac{0.4 \mathrm{~m}^{3}}{\mathrm{~kg} \cdot \mathrm{d}} \times \frac{14 \mathrm{hr}}{d} \times 58 \mathrm{~kg} \times \frac{1 \mathrm{~d}}{24 \mathrm{hr}} \times \frac{365 d}{\mathrm{yr}}=0.53 \mathrm{~L} \mathrm{yr}
\end{aligned}
$$

Inhalation exposure (IE) was calculated by the expression

$$
I E=I E F_{\text {shower }}+\text { Bathroom + house }\left(L \cdot y r^{-1}\right) \times\left[{ }^{3} H\right]_{\text {receptor }}\left(p C i \cdot L^{-1}\right)=p C i \cdot y r^{-1}
$$

\section{Dermal exposure}

Two activities contribute to wholebody dermal exposure (DE): showering and swimming. DE was estimated in two steps by the methods of McKone and coworkers $(1991,1992)$, using the distributions of exposure factors in Table 5.7. The first step was to determine the dermal uptake of water from both activities

\section{Dermal Uptake of Water $(D U)=S A \times F s a \times K p \times D \times N E \times C F$}

$S A=$ Surface area of $\operatorname{skin}\left(\mathrm{m}^{2}\right)$

$F_{S A}=$ Fraction of surface area exposed;

$K \mathrm{~K}=$ Dermal permeability constant for tritium ( $\mathrm{m} / \mathrm{hr}$; Bronaugh et al., 1980);

$D=$ Duration of exposure: $D_{\text {shower }}\left(\mathrm{hr}^{-d^{-1}}\right)$; and $\mathrm{D}_{\text {swimming }}\left(\mathrm{hroyr}^{-1}\right)$;

$\mathrm{NE}=$ Number of events $\left(\mathrm{d}^{\mathrm{y}} \mathrm{yr} \mathrm{r}^{-1}\right): \mathrm{NE}_{\text {shower }}=365 \mathrm{~d}^{\mathrm{y}} \mathrm{yr} \mathrm{r}^{-1}$;

$\mathrm{CF}=$ Conversion Constant $\left(10^{3}{\left.\mathrm{~L} \cdot \mathrm{m}^{-3}\right)}\right.$.

By substitution of the average values from Table 5.7:

$$
\mathrm{DU}=1.5 \mathrm{~m}^{2} \times 0.65 \times \frac{1.5 \times 10^{-5} \mathrm{~m}}{\mathrm{hr}} \times\left[\left(\frac{.13 \mathrm{hr}}{d} \times \frac{365 d}{y r}\right)+\frac{8.9 \mathrm{hr}}{y r}\right] \times \frac{1000 \mathrm{~L}}{\mathrm{~m}^{3}}=0.824 \mathrm{~L} \cdot \mathrm{yr}-1
$$

$D E$ is then calculated by the expression

$$
D E=D U\left(L \cdot y r^{-1}\right) \times\left[{ }^{3} H\right]_{\text {receptor }}\left(p C i \cdot L^{-1}\right)=p C i \bullet y r^{-1}
$$


Table 5.10. Total Annual Exposures ( $\mathrm{pCi}$ ) to Tritium (as HTO) in the Beaufort-Jasper and Port Wentworth Water Supplies: Average (Arithmetic Mean) and Maximum Values for Each Scenario.

Scenario 1

Scenario 2

Scenario 3

\begin{tabular}{ccccccc|}
\hline Year & Average & Maximum & Average & Maximum & Average & Maximum \\
\hline \hline 1992 & $4.4 E+5$ & $3.5 E+6$ & $6.0 E+5$ & $5.2 E+6$ & $8.5 E+5$ & $6.9 E+6$ \\
1993 & $4.7 E+5$ & $2.6 E+6$ & $6.3 E+5$ & $5.1 E+6$ & $8.8 E+5$ & $1.9 E+7$ \\
1994 & $4.4 E+5$ & $3.5 E+6$ & $6.0 E+5$ & $5.2 E+6$ & $8.5 E+5$ & $6.9 E+6$ \\
1995 & $3.5 E+5$ & $2.4 E+6$ & $5.1 E+5$ & $4.5 E+6$ & $7.6 E+5$ & $9.7 E+6$ \\
1996 & $3.8 E+5$ & $3.1 E+6$ & $5.4 E+5$ & $4.7 E+6$ & $7.9 E+5$ & $4.4 E+6$ \\
1997 & $2.9 E+5$ & $1.4 E+6$ & $4.5 E+5$ & $2.5 E+6$ & $7.0 E+5$ & $4.3 E+6$ \\
1998 & $2.6 E+5$ & $3.2 E+6$ & $5.0 E+5$ & $7.2 E+6$ & $6.7 E+5$ & $3.9 E+6$ \\
1999 & $2.3 E+5$ & $1.5 E+6$ & $4.8 E+5$ & $8.0 E+6$ & $6.5 E+5$ & $5.1 E+6$ \\
2000 & $1.8 E+5$ & $9.1 E+5$ & $4.2 E+5$ & $3.8 E+6$ & $5.9 E+5$ & $6.1 E+6$ \\
2001 & $1.3 E+5$ & $1.9 E+6$ & $3.7 E+5$ & $5.2 E+6$ & $5.4 E+5$ & $6.1 E+6$ \\
2002 & $7.9 E+4$ & $8.8 E+5$ & $3.2 E+5$ & $4.0 E+6$ & $4.9 E+5$ & $4.6 E+6$ \\
2003 & $3.2 E+4$ & $2.3 E+5$ & $2.7 E+5$ & $2.1 E+6$ & $4.4 E+5$ & $2.3 E+6$ \\
2004 & & & $2.4 E+5$ & $1.1 E+6$ & $4.1 E+5$ & $2.7 E+6$ \\
\hline
\end{tabular}

The Total Annual Exposure (TAE) for each year was obtained by adding the results from equations (10), (14), (16) and:(21). The TAE for each of years 1992-2004 are described in Table 5.10 for individuals in the receptor populations that receive their domestic raw water supplies from the Savannah River.

As previously explained, from 2004 onwards, discharges into the Savannah River of tritium released into the groundwater from operations prior to 1989 will be negligible. Therefore, distributions of the annual releases of tritium from the SRS and the resulting TAEs are expected to remain unchanged.

\subsection{Conversion of Tritiated Water Exposure to Dose (Factor for converting $\mathrm{pCi}$ to mGy)}

A lognormal distribution of the committed equivalent dose (CED, in soft tissues) per intake of unit activity of tritiated water was calculated from Table 1.1-2 in ICRP 1979, assuming a 10\% dose contribution from organically bound tritium (ICRP, 1979, 1989). The average CED was

$1.76 \times 10^{-11} \mathrm{~Sv} / \mathrm{Bq}\left(\mathrm{SD}, 5.15 \times 10^{-11}\right)$. This distribution corresponds to a lognormal distribution of the annual absorbed dose factor (ADF), averaging $6.5 \times 10^{-10} \mathrm{mGy} / \mathrm{pCi}\left(\mathrm{SD}, 1.9 \times 10^{-10}\right.$ ), using a value of one for the quality factor (Q) for tritium beta radiation (equation 22 ).

$$
C E D\left(\frac{S v}{B q}\right) \times \frac{1 G y}{1 S \nu} \times \frac{3.7 \times 10^{10} B q}{C i} \times \frac{10^{-12} C i}{p C i} \times \frac{10^{3} m G y}{G y}=A D F\left(\frac{m G y}{p C i}\right)
$$

To calculate the annual wholebody dose (AD; in mGy), the distribution of each Total Annual Exposure (TAE; in pCi) was multiplied by the distribution of ADF:

$$
A D=\operatorname{TAE}(p C i) \times A D F(m G y / p C i)=m G y
$$


Table 5.11. Annual Absorbed Doses (mGy) Resulting from Exposures to Tritium (as HTO) in the Beaufort-Jasper and Port Wentworth Water Supplies: Average (Arithmetic Mean) and Maximum Values for Each Scenario.

Scenario 1

Scenario 2

Scenario 3

\begin{tabular}{|ccccccc|}
\hline Year & Average & Maximum & Average & Maximum & Average & Maximum \\
\hline \hline 1992 & $2.8 \mathrm{E}-4$ & $2.2 \mathrm{E}-3$ & $3.8 \mathrm{E}-4$ & $3.3 \mathrm{E}-3$ & $5.4 \mathrm{E}-4$ & $4.3 \mathrm{E}-3$ \\
1993 & $3.0 \mathrm{E}-4$ & $1.6 \mathrm{E}-3$ & $4.0 \mathrm{E}-4$ & $3.2 \mathrm{E}-3$ & $5.6 \mathrm{E}-4$ & $1.2 \mathrm{E}-2$ \\
1994 & $2.8 \mathrm{E}-4$ & $2.2 \mathrm{E}-3$ & $3.8 \mathrm{E}-4$ & $3.3 \mathrm{E}-3$ & $5.4 \mathrm{E}-4$ & $4.3 \mathrm{E}-3$ \\
1995 & $2.2 \mathrm{E}-4$ & $1.5 \mathrm{E}-3$ & $3.2 \mathrm{E}-4$ & $2.8 \mathrm{E}-3$ & $4.8 \mathrm{E}-4$ & $6.1 \mathrm{E}-3$ \\
1996 & $2.4 \mathrm{E}-4$ & $2.0 \mathrm{E}-3$ & $3.4 \mathrm{E}-4$ & $3.0 \mathrm{E}-3$ & $5.0 \mathrm{E}-4$ & $2.8 \mathrm{E}-3$ \\
1997 & $1.8 \mathrm{E}-4$ & $8.5 \mathrm{E}-3$ & $2.8 \mathrm{E}-4$ & $1.6 \mathrm{E}-3$ & $4.4 \mathrm{E}-4$ & $2.7 \mathrm{E}-3$ \\
1998 & $1.6 \mathrm{E}-4$ & $2.0 \mathrm{E}-3$ & $3.2 \mathrm{E}-4$ & $4.6 \mathrm{E}-3$ & $4.2 \mathrm{E}-4$ & $2.4 \mathrm{E}-3$ \\
1999 & $1.5 \mathrm{E}-4$ & $9.6 \mathrm{E}-4$ & $3.0 \mathrm{E}-4$ & $5.1 \mathrm{E}-3$ & $4.1 \mathrm{E}-4$ & $3.2 \mathrm{E}-3$ \\
2000 & $1.1 \mathrm{E}-4$ & $5.8 \mathrm{E}-4$ & $2.6 \mathrm{E}-4$ & $2.4 \mathrm{E}-3$ & $3.7 \mathrm{E}-4$ & $3.8 \mathrm{E}-3$ \\
2001 & $3.1 \mathrm{E}-5$ & $1.2 \mathrm{E}-3$ & $2.3 \mathrm{E}-4$ & $3.3 \mathrm{E}-3$ & $3.4 \mathrm{E}-4$ & $3.8 \mathrm{E}-3$ \\
2002 & $5.0 \mathrm{E}-5$ & $5.6 \mathrm{E}-4$ & $2.0 \mathrm{E}-4$ & $2.5 \mathrm{E}-3$ & $3.1 \mathrm{E}-4$ & $2.9 \mathrm{E}-3$ \\
2003 & $2.0 \mathrm{E}-5$ & $1.8 \mathrm{E}-4$ & $1.7 \mathrm{E}-4$ & $1.3 \mathrm{E}-3$ & $2.8 \mathrm{E}-4$ & $1.8 \mathrm{E}-3$ \\
2004 & & & $1.5 \mathrm{E}-4$ & $7.0 \mathrm{E}-4$ & $2.6 \mathrm{E}-4$ & $1.7 \mathrm{E}-3$ \\
\hline
\end{tabular}

Table 5.11 describes 1992-2004 values obtained from distributions of annual doses to a receptor population that receives its domestic raw water supply from the Savannah River. It was assumed that from 2004 onwards, there would be no discharges into surface waters of groundwater tritium resulting from operations prior to 1989. The distributions of TAE and AD for each of all subsequent years are expected to be similar to 2004, for tritium releases from continued operations of K-Reactor (Scenarios 2 and 3 ). The role of other types of operations that release tritium to surface waters (e.g., chemical separations) will be discussed under the section on uncertainties (5.7.5).

For low LET radiation, $1 \times 10^{-2} \mathrm{mGy}$ absorbed dose $=1$ mrem effective dose (ED). The expected annual doses from tritium (Table 5.11) exceed neither the current EPA drinking water standard of $1.3 \times 10^{-2} \mathrm{mGy}$ (based on a concentration of $2 \times 10^{4} \mathrm{pCi} / \mathrm{L}$ ) for tritium nor the proposed standard of $4 \times 10^{-2} \mathrm{mGy}$ (based on a concentration of $6 \times 10^{4} \mathrm{pCi} / \mathrm{L}$ : USEPA, 1991).

\subsection{Risk Characterization-Cancer Mortality (Straume 91)}

The following equation describes the factor (or risk coefficient) for excess individual lifetime cancer mortality risk from low-level exposure to HTO, as described in detail by Straume (1991):

$$
R_{c, \text { HTO }}=\left[\frac{R_{n, a, Y}}{D R E F}+R_{\ell, c, Y}\right] \times R B E_{c, \text { HTO }}
$$


where,

$\mathbf{R}_{\mathrm{c}, \text { нто }}$

$=$ Excess individual lifetime cancer mortality risk factor for chronic (c) exposure to tritiated water (HTO).

$\mathrm{R}_{\mathrm{n}, \mathrm{a}, \gamma}$

$=$ Non leukemia $(n)$ cancer mortality risk for acute (a) exposures to gamma $(\gamma)$ radiation; assuming a male to female ratio of unity in a population with an age distribution that is identical to that in the United States as a whole.

DREF

$=$ Dose-rate effectiveness factor, a ratio that is the slope of the linear curve fitted to acute high-level radiation data divided by the slope of the linear curve fitted to chronic exposure data for the same radiation and biological endpoint; in this case, gamma-ray-induced tumors in laboratory studies using animals.

$\mathrm{R}_{1, \mathrm{c}, \gamma} \quad=$ Leukemia (l) risk for chronic low-level exposures to $\gamma$ radiation, obtained from the linear part of the linear-quadratic curve for acute high-level exposures to $\%$ radiation.

RBE $_{\text {c, nro }}=$ Relative biological effectiveness for HTO, as derived by Straume (1991), is the dose from chronic gamma rays divided by the dose from HTO beta radiation that results in the same level of biological damage in the same biological system.

According to the derivation by Straume (1991), $R_{c, \text { Irro }}$ is a lognormally distributed variable with a geometric mean equal to $68 \times 10^{-6}$ deaths per $\mathrm{mGy}$ and a derived total geometric standard deviation of 1.6. Straume used data presented in BEIR V (NRC, 1990) to obtain best-estimate values and distributions for $R_{n, a}, \gamma, D R E F$, and $R_{1}, c, \gamma$. The best-estimate values and distributions for $\mathrm{RBE}_{\mathrm{c} \text {, Iто }}$ and $\mathrm{R}_{\mathrm{c} \text {, нто }}$ were derived in Straume (1991).

\subsubsection{Incremental Individual Risks (IR) for cancer death from exposure to tritium in} domestic water supplies.

Individual risk (IR) was calculated by multiplying the annual dose (mGy) by the risk factor (deaths $\bullet \mathrm{mgy}^{-1}$ ):

$$
\mathbb{I R}=A D \times R_{\mathrm{c}, \text {, }} \text {, }
$$

Table 5.12 describes values obtained from 1992-2004 distributions of incremental individual lifetime risks of cancer death in receptor populations that receive their domestic water supplies from the Savannah River. For each year from 2004 onwards, the distributions of annual total exposures, doses, and incremental individual risks are expected to remain unchanged because of the absence of any groundwater release of tritium from operations prior to 1989.

The total Incremental Individual Risks depend on both the numbers of years of exposure to water supplied by the Beaufort-Jasper facility, and in which years the exposures occur. For any given scenario, an individual whose exposure starts in or after the year 2004 would face the lowest total risk compared to an individual whose exposure of the same duration starts before that year. To calculate the expected risk for any duration of exposure, the risk coefficient $\left(R_{c, \text { нто }}\right)$ must be multiplied by the sum of the annual doses. 
Table 5.12. Incremental Individual Lifetime Mortality Risks from Annual Exposures to Tritium (as HTO) in the Beaufort-Jasper Water and Port Wentworth Water Supplies: Arithmetic Average, Median and Upper ( $\uparrow$ ) $95 \%$ Confidence Limit Values.

\begin{tabular}{|c|c|c|c|c|c|c|c|c|c|}
\hline & \multicolumn{9}{|c|}{ Scenario } \\
\hline & & $\overline{1}$ & & & 2 & & & 3 & \\
\hline Year & Average & Median & $\uparrow 95 \%$ & Average & Median & $\uparrow 95 \%$ & Average & Median & $\uparrow 95 \%$ \\
\hline $\begin{array}{l}1992 \\
1993 \\
1994 \\
1995 \\
1996 \\
1997 \\
1998 \\
1999 \\
2000 \\
2001 \\
2002 \\
2003 \\
2004 \\
\end{array}$ & $\begin{array}{l}1.9 \mathrm{E}-8 \\
2.0 \mathrm{E}-8 \\
1.9 \mathrm{E}-8 \\
1.5 \mathrm{E}-8 \\
1.6 \mathrm{E}-8 \\
1.3 \mathrm{E}-8 \\
1.1 \mathrm{E}-8 \\
1.0 \mathrm{E}-8 \\
7.5 \mathrm{E}-9 \\
5.5 \mathrm{E}-9 \\
3.4 \mathrm{E}-9 \\
1.4 \mathrm{E}-9\end{array}$ & $\begin{array}{l}1.8 \mathrm{E}-8 \\
1.9 \mathrm{E}-8 \\
1.8 \mathrm{E}-8 \\
1.4 \mathrm{E}-8 \\
1.5 \mathrm{E}-8 \\
1.2 \mathrm{E}-8 \\
1.0 \mathrm{E}-8 \\
9.4 \mathrm{E}-9 \\
7.2 \mathrm{E}-9 \\
5.3 \mathrm{E}-9 \\
2.9 \mathrm{E}-9 \\
1.7 \mathrm{E}-9\end{array}$ & $\begin{array}{l}1.4 \mathrm{E}-7 \\
1.1 \mathrm{E}-7 \\
1.4 \mathrm{E}-7 \\
1.0 \mathrm{E}-7 \\
1.3 \mathrm{E}-7 \\
5.8 \mathrm{E}-8 \\
1.3 \mathrm{E}-7 \\
6.5 \mathrm{E}-8 \\
4.0 \mathrm{E}-8 \\
8.1 \mathrm{E}-8 \\
3.9 \mathrm{E}-8 \\
1.2 \mathrm{E}-8\end{array}$ & $\begin{array}{l}2.6 \mathrm{E}-8 \\
2.7 \mathrm{E}-8 \\
2.6 \mathrm{E}-8 \\
2.2 \mathrm{E}-8 \\
2.3 \mathrm{E}-8 \\
1.9 \mathrm{E}-8 \\
2.2 \mathrm{E}-8 \\
2.1 \mathrm{E}-8 \\
1.8 \mathrm{E}-8 \\
1.6 \mathrm{E}-8 \\
1.4 \mathrm{E}-8 \\
1.2 \mathrm{E}-8 \\
1.0 \mathrm{E}-8 \\
\end{array}$ & $\begin{array}{l}2.6 \mathrm{E}-8 \\
2.5 \mathrm{E}-8 \\
2.6 \mathrm{E}-8 \\
2.0 \mathrm{E}-8 \\
2.2 \mathrm{E}-8 \\
1.9 \mathrm{E}-8 \\
2.0 \mathrm{E}-8 \\
1.9 \mathrm{E}-8 \\
1.7 \mathrm{E}-8 \\
1.5 \mathrm{E}-8 \\
1.3 \mathrm{E}-8 \\
1.1 \mathrm{E}-8 \\
9.6 \mathrm{E}-9\end{array}$ & $\begin{array}{l}2.2 \mathrm{E}-7 \\
2.3 \mathrm{E}-7 \\
2.2 \mathrm{E}-7 \\
1.9 \mathrm{E}-7 \\
2.0 \mathrm{E}-7 \\
1.1 \mathrm{E}-7 \\
3.0 \mathrm{E}-7 \\
3.4 \mathrm{E}-7 \\
1.6 \mathrm{E}-7 \\
2.3 \mathrm{E}-7 \\
1.7 \mathrm{E}-7 \\
9.2 \mathrm{E}-8 \\
4.7 \mathrm{E}-8 \\
\end{array}$ & $\begin{array}{l}3.6 \mathrm{E}-8 \\
3.8 \mathrm{E}-8 \\
3.6 \mathrm{E}-8 \\
3.3 \mathrm{E}-8 \\
3.4 \mathrm{E}-8 \\
3.0 \mathrm{E}-8 \\
2.9 \mathrm{E}-8 \\
2.8 \mathrm{E}-8 \\
2.5 \mathrm{E}-8 \\
2.3 \mathrm{E}-8 \\
2.1 \mathrm{E}-8 \\
1.9 \mathrm{E}-8 \\
1.8 \mathrm{E}-8 \\
\end{array}$ & $\begin{array}{l}3.4 \mathrm{E}-8 \\
5.0 \mathrm{E}-8 \\
3.4 \mathrm{E}-8 \\
3.0 \mathrm{E}-8 \\
3.2 \mathrm{E}-8 \\
2.8 \mathrm{E}-8 \\
2.7 \mathrm{E}-8 \\
2.6 \mathrm{E}-8 \\
2.4 \mathrm{E}-8 \\
2.2 \mathrm{E}-8 \\
2.0 \mathrm{E}-8 \\
1.8 \mathrm{E}-8 \\
1.6 \mathrm{E}-8 \\
\end{array}$ & $\begin{array}{l}2.8 E-7 \\
7.8 E-7 \\
2.8 E-7 \\
4.1 E-7 \\
1.9 E-7 \\
1.8 E-7 \\
1.7 E-7 \\
2.2 E-7 \\
2.7 E-7 \\
2.6 E-7 \\
2.0 E-7 \\
1.2 E-7 \\
1.2 E-7\end{array}$ \\
\hline
\end{tabular}

Theoretically, the largest risk would be incurred by an individual exposed to tritium under Scenario 3 from birth in 1992 through death seventy years later. Based upon summation of the IRs for each year, such an individual's average incremental risk for cancer mortality would be $1.4 \times 10^{-6}$ (SD, 4.2 $\times 10^{-7}$; upper $95 \%$ confidence limit, $\left.2.8 \times 10^{-6}\right)$. This distribution is at the lower end of the US EPA's range of acceptable risk of $10^{-6}$ to $10^{-4}$ under current drinking water standards for tritium, and iwo orders of magnitude below the limit of proposed regulations (Federal Register, 1991).

For a given period of exposure, Scenario 1 (the absence of further operations) yielded the lowest expected risk of an individual suffering a lifetime cancer mortality from tritium in domestic raw water obtained from the Savannah River.

For operations at the same level, the expected risks are lower when part of the tritium effluent is allowed to reach surface waters by way of ground water migration (Scenario 2) than when all the effluent is directly released from processes to surface waters (Scenario 3). Under Scenario 2, approximately $40 \%$ of the tritium originally released to the ground water would be gone after 10 years of seepage migration to surface water, based on tritium's half-life of 12.3 years.

Current plans call for the K-Reactor to operate under Scenario 3. Under this Scenario, the distribution of tritium concentrations in receptor water from 1993 (the year with the maximum exposure values) and the current US EPA drinking water standard (Table 5.13) were run through the same Monte Carlo risk analysis simulations, using the PEFs and dose-relationships described in the preceding sections. The calculated expected levels of risk from receptor tritium concentrations are almost an order of magnitude below the limits prescribed in the current EPA drinking water standard (Figure 5.2, Table 5.13). Proposed new EPA drinking water standards (6 X $10^{4} \mathrm{pCi} / \mathrm{L} ;$ Federal Register, 1991) are threefold higher than the current standards. 
Figure 5.2. Comparison of Frequency Distributions for Incremental Individual risks (IR) from Estimated 1993 Tritium Concentrations in Savannah River Drinking Water to the Distributions Estimated for the USEPA Standard for Drinking Water.

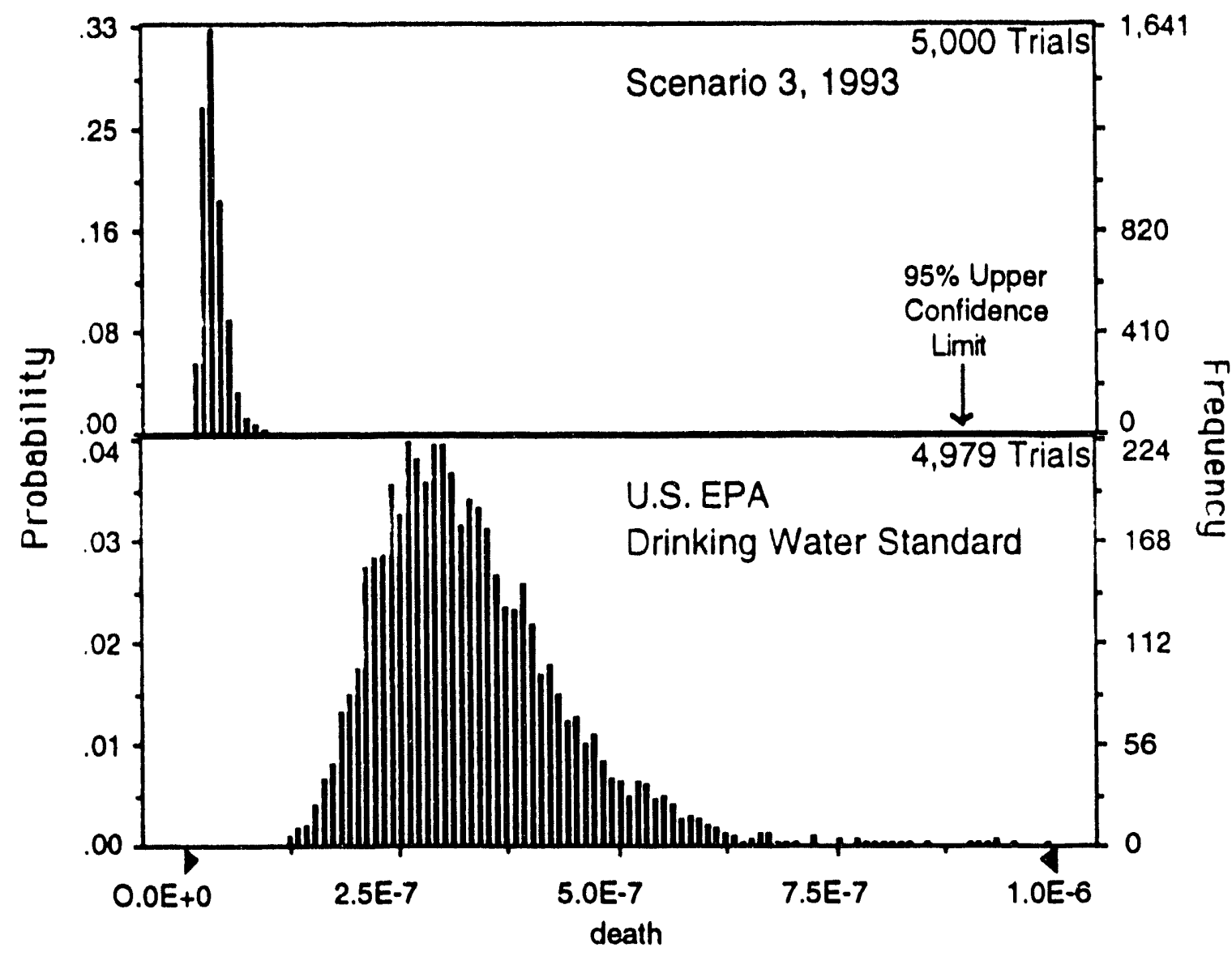

Table 5.13. Comparison of Statistics for Predicted 1993 Receptor Concentrations of Tritium (Scenario 3) to Statistics for the Current USEPA Drinking Water Standard.

\begin{tabular}{|c|c|c|c|c|c|c|}
\hline & $\begin{array}{r}\text { Water C } \\
\text { (f }\end{array}$ & $\begin{array}{l}\text { centration } \\
\text { i/L) }\end{array}$ & Total An & $\begin{array}{l}\text { al Intake } \\
\text { i) }\end{array}$ & $\begin{array}{r}\text { Incremen } \\
\text { (cancer }\end{array}$ & $\begin{array}{l}\text { ndividual } \\
\text { rtality) }\end{array}$ \\
\hline & Expected & Range & Average & Maximum & Averageb & $\begin{array}{l}\text { T95\% } \\
\text { Limit }\end{array}$ \\
\hline $\begin{array}{l}\text { Receptor Sitea } \\
\text { EPA Standardc }\end{array}$ & $\begin{array}{l}2230 \\
20000\end{array}$ & $1360-2980$ & $\begin{array}{l}8.8 E+5 \\
8.6 E+6\end{array}$ & $\begin{array}{l}1.9 \mathrm{E}+7 \\
7.7 \mathrm{E}+7\end{array}$ & $\begin{array}{l}3.8 \mathrm{E}-8 \\
3.7 \mathrm{E}-7\end{array}$ & $\begin{array}{l}7.8 \mathrm{E}-7 \\
3.5 \mathrm{E}-6\end{array}$ \\
\hline
\end{tabular}

aBeaufort-Jasper or Port Wentworth Drinking Water Plant

bArithmetic Mean

cProposed new standard is $6 \times 10^{4} \mathrm{pCi} / \mathrm{L}$.

The upper $95 \%$ confidence limit for IR in Scenario 3 is below the ordinate maximum of $1 \times 10.6$ deaths in Figure 5.3, which in turn is $78 \%$ below the upper $95 \%$ confidence limit for the current EPA standard (Table 5.12). The average IR for Scenario 3 is an order of magnitude below the average for the current EPA standard (Table 5.13). 
5.7.2 Calculate the population risk (PR) for a receptor population:

$$
P R=N \times T A E \times D \times R_{c, 1}
$$

where, $P R$ is the incremental number of cancer deaths in a population of size $N$, resulting from exposure to Savannah River water containing tritium from the SRS.

For the water processing plants, $N$ increases in 10 even increments from 1991-2000. The increased service was assumed to occur in 10 even increments because the actual rate of increase in service is unknown. Maximum population sizes are based upon expected increases in capacity of the water processing plants by the year 2000 (USDOE, 1990), rather than population growth per se. The Beaufort-Jasper supply was assumed to increase by 6600 people annually, from 51,000 to 117,000. The Port Wentworth water processing plant (Cherokee Hill) currently serves an industrial population of 15,000 (Hamby, 1991). The plant is expected to increase its supply to an additional residential population of 200,000 by the year 2000 (USDOE, 1990; H. Jue, personal communication).

Table 5.14. Incremental Number of Cancer Deaths Resulting from Annual Exposures of Populations to Tritium (as HTO) in the Beaufort-Jasper Water Supply: Upper ( $\uparrow$ ) $95 \%$ Confidence Limit Values.

\begin{tabular}{|c|c|c|c|c|}
\hline \multirow{2}{*}{ Year } & Population & Scenario 1 & Scenario 2 & Scenario 3 \\
\cline { 3 - 5 } & Deaths & Deaths & Deaths \\
\hline \hline 1992 & 64200 & 0.003 & 0.005 & 0.007 \\
\hline 1993 & 70800 & 0.003 & 0.005 & 0.020 \\
\hline 1994 & 77400 & 0.004 & 0.006 & 0.008 \\
\hline 1995 & 84000 & 0.003 & 0.006 & 0.012 \\
\hline 1996 & 90600 & 0.004 & 0.006 & 0.006 \\
\hline 1997 & 97200 & 0.002 & 0.004 & 0.006 \\
\hline 1998 & 103800 & 0.005 & 0.011 & 0.006 \\
\hline 1999 & 110400 & 0.002 & 0.013 & 0.008 \\
\hline 2000 & 117000 & 0.002 & 0.007 & 0.011 \\
\hline 2001 & 117000 & 0.003 & 0.009 & 0.011 \\
\hline 2002 & 117000 & 0.002 & 0.007 & 0.008 \\
\hline 2003 & 117000 & 0.000 & 0.004 & 0.005 \\
\hline 2004 & 117000 & 0.000 & 0.002 & 0.005 \\
\hline
\end{tabular}

Tables 5.14 and 5.15 show the results of a first level screen, expressed as the upper $95 \%$ confidence limit for incremental deaths from cancer in each population. From 2004 onwards, distributions of total annual exposures are expected to remain unchanged, in the absence of groundwater migration of tritium from operations prior to 1989. The calculations are hyperconservative because they are based upon maximal values for each TAE. No excess death from cancer is expected at any time for any of the populations at risk, especially since the average TAEs (Table 5.9) for the populations are well below the values used in these calculations. 
Table 5.15. Incremental Number of Cancer Deaths Resulting from Annual Exposures of Populations to Tritium (as HTO) in the Port Wentworth Water Supply: Upper ( $\uparrow$ ) $95 \%$ Confidence Limit Values.

\begin{tabular}{|c|c|c|c|c|}
\hline \multirow{3}{*}{ Year } & Population & Scenario 1 & Scenario 2 & Scenario 3 \\
\cline { 3 - 5 } & Deaths & Deaths & Deaths \\
\hline 1992 & 40000 & 0.002 & 0.003 & 0.004 \\
\hline 1993 & 60000 & 0.002 & 0.005 & 0.017 \\
\hline 1994 & 80000 & 0.004 & 0.006 & 0.008 \\
\hline 1995 & 100000 & 0.004 & 0.007 & 0.014 \\
\hline 1996 & 120000 & 0.006 & 0.008 & 0.008 \\
\hline 1997 & 140000 & 0.003 & 0.005 & 0.009 \\
\hline 1998 & 160000 & 0.008 & 0.017 & 0.009 \\
\hline 1999 & 180000 & 0.004 & 0.021 & 0.014 \\
\hline 2000 & 200000 & 0.003 & 0.011 & 0.018 \\
\hline 2001 & 200000 & 0.006 & 0.015 & 0.018 \\
\hline 2002 & 200000 & 0.003 & 0.012 & 0.014 \\
\hline 2003 & 200000 & 0.001 & 0.006 & 0.008 \\
\hline 2004 & 200000 & 0.000 & 0.003 & 0.008 \\
\hline
\end{tabular}

5.7.3 Risk Analysis for the Industrial Population Exposed to Tritium in the Port Wentworth Water Supply.

The 15,000 industrial population at Port Wentworth is assumed to be exposed to tritium in drinking water and by dermal absorption (washing at work). In a screening simulation in which conservative assumptions were used in our exposure model. It was also assumed that the $\left[{ }^{3} \mathrm{H}\right]$ in the water is $3 \times 10^{3} \mathrm{pCi}$ per $\mathrm{L}$, a concentration that exceeds the highest receptor concentration in Table 5.6 (Scenario 3). Under these conditions, individual risk is no higher than the Individual risks for residential exposures.

The total annual exposure (TAE) was calculated by adding the intake from water ingestion (WIE) at work to the dermal intake from washing at work (DE).

$$
\mathrm{WIE}=\left[{ }^{3} H\right] \times \mathrm{WI} \times \mathrm{F} \times \mathrm{D}
$$

$\left[{ }^{3} \mathrm{H}\right]=\frac{3 \times 10^{3} p C_{1}}{L}$

$\mathrm{WI}=$ rate of water ingestion $=1{\mathrm{~L} \cdot \mathrm{d}^{-1}}^{-1}(\mathrm{USEPA}, 1991)$

$\mathrm{F}=$ frequency $=250 \mathrm{~d} \cdot \mathrm{yr}^{-1}($ USEPA, 1991)

$\mathrm{D}=$ duration $=1 \mathrm{yr}$

Substituting the values into equation 27 :

$$
W I E=\frac{3 \times 10^{3} p C i}{L} \times \frac{1 L}{d} \times \frac{250 d}{y r} \times 1 y r=7.5 \times 10^{5} p C i
$$




$$
D E=\left[{ }^{3} H\right] \times S A \times K p \times t \times C f_{1} \times F \times D u \times C f_{v}
$$

$\mathrm{SA}=0.44 \mathrm{~m}^{2}$ surface area (head \& upper extremities of an adult male; USEPA, 1985)

$\mathrm{Kp}=$ permeability constant for water $=1.5 \times 10^{-5} \mathrm{~m}^{\circ} \mathrm{hr}-1$ (Table 5.6)

$t=$ time $=10$ min $^{\prime} d a y^{-1}$ (USEPA default, 1991)

$\mathrm{Cf}_{\mathrm{t}}=$ Time Conversion Factor $=0.017 \mathrm{hr} \cdot \mathrm{min}^{-1} ; \mathrm{Cf}_{\mathrm{v}}=$ Volume Conversion Factor $=10^{3} \mathrm{Li}_{\mathrm{i}} \mathrm{M}^{3}$

Substituting numerical values into equation 29:

$$
\begin{aligned}
& D E=\frac{3 \times 10^{3} \mathrm{pCi}}{L} \times 0.44 \mathrm{~m}^{2} \times \frac{1.5 \times 10^{-5} \mathrm{~m}}{\mathrm{hr}} \times \frac{10 \mathrm{~min}}{d a y} \times \frac{0.017 \mathrm{hr}}{\mathrm{min}} \times \frac{250 \mathrm{~d}}{y r} \times 1 y r \frac{10^{3} \mathrm{~L}}{\mathrm{~m}^{3}}=8.2 \times 10^{5} \mathrm{pCi} \\
& T A E=\text { WIE }+D E=\left(7.5 \times 10^{5} \mathrm{pCi}\right)+\left(8.2 \times 10^{5} \mathrm{pCi}\right)=1.6 \times 10^{6} \mathrm{pCi}
\end{aligned}
$$

From equation 23:

$$
\begin{aligned}
& A D=\left(1.6 \times 10^{6} \mathrm{pCi}\right) \times\left(6.3 \times 10^{-10} \mathrm{mGy}^{\bullet} \mathrm{Ci}^{-1}\right)=9.9 \times 10^{-4} \mathrm{mGy} \\
& \mathbb{R}_{\text {average }}=\left(9.9 \times 10^{-4} \mathrm{mGy}\right) \times\left(6.8 \times 10^{-6} \text { cieaths } \bullet \mathrm{mGy}^{-1}\right)=6.7 \times 10^{-8} \text { deaths }
\end{aligned}
$$

Results from the equations reflect values transcribed from spreadsheet calculations. Over a 50 year workspan, with exposures at the same level, the $\mathbb{R}_{\text {average }}$ would be only $3.4 \times 10^{-6}$ deaths. Therefore a detailed analysis, as performed for residential populations, was not performed for the industrial population at Port Wentworth.

\subsubsection{Sensitivity Analysis}

A risk analysis for only one exposure pathway per Monte Carlo simulation was performed to estimate the relative contributions of the exposure pathways to health risks in the residential populations. The pathways were analyzed at the estimated 1993 distribution of tritium concentrations in the drinking water consumed by the receptor populations, under Scenario 3. The major pathways of exposure to tritium in Savannah River drinking water were ranked in the order Ingestion>Inhalation>Dermal. Approximately $84 \%$ of the average IR comes from drinking tritiated water. Exposures from freshwater-finfish ingestion are overestimated because cooking processes tend to remove portions of the tritiated water. Nevertheless, in comparison to other exposure pathways, the contribution to the overall risk calculations from fish ingestion is negligible, even if cooking is not taken into account. The average risks from ingestion of fish, or from dermal exposure during showers and swimming are two to three orders of magnitude lower than the average risk from water ingestion.

The remainder of the total expected IR is attributed to indoor inhalation of tritiated water vapor: approximately $14 \%$ for the shower; $1 \%$ for the bathroom. The risk from inhalation in the house is three orders of magnitude lower than from inhalation in the shower and bathroom. In summary, the major pathways of exposure to tritium in the Savannah River are drinking the water and inhalation of water vapor in the shower. 
A sensitivity analysis was also used to identify major factors, other than exposure pathways, that contribute to the uncertainties in the risk assessment. Each simulation run consisted of a thousand iterations, in which the IR to receptors from all distributions was compared to the IR when an average value was substituted for one of the distributions in a simulation run. It is obvious from Table 5-15 that substitutions for either the annual water flow (volume) in the Savannah River or the cancer mortality risk factor had relatively little effect on the IR values. Use of the average annual river volume produced the greater change, an approximate $18 \%$ reduction in the IR.

Table 5-16. Results of Sensitivity Analysis for Major Parameters in Overall Uncertainties of Individual Risk (Cancer Mortality) Estimates.

\begin{tabular}{|l|c|c|c|}
\hline Parameter Restricted & Average Value of & \multicolumn{2}{|c|}{ Individual Risk } \\
\cline { 3 - 4 } to Average Value & Parameter & Average & Upper $95 \%$ \\
\hline \hline None & & $2.3 \mathrm{E}-8$ & $3.8 \mathrm{E}-8$ \\
Annual River Volume & $9.3 \mathrm{E}+12 \mathrm{~L}$ & $1.9 \mathrm{E}-8$ & $3.1 \mathrm{E}-8$ \\
Risk Factor & $6.8 \mathrm{E}-5$ deaths/mGy & $2.3 \mathrm{E}-8$ & $3.8 \mathrm{E}-8$ \\
\hline
\end{tabular}

\subsubsection{Uncertainties}

Generally, the uncertainties in parameters used in this assessment are described as distributions in the preceding sections of this assessment. Nevertheless, the uncertainties associated with specific topics require further discussion, primarily because of information received after the risk analysis was completed. These uncertainties will be described below.

\section{Source Terms}

The ten-year migration from seepage-to-surface-water model is based upon fractional changes in 1980 1989 total releases from operations, with seepage migrations either dominating or forming a considerable fraction of the releases to surface waters from 1990-1999 (Tables 5.3, 5.4, 5.5). The model predicts that seepage migration contributes $1.15 \times 10^{4} \mathrm{Ci}$ of tritium to surface waters in 1990 . A recent acquisition of the SRS Environmental Report for 1990 (Cummins et al., 1991) shows that this prediction is $15 \%$ under the actual release of $1.35 \times 10^{4} \mathrm{Ci}$. The difference in seepage migration may be explained by a series of droughts that occurred from 1979-1985. These droughts killed many of the onsite trees. The trees ordinarily take up a large amount of tritiated water from the ground water (Brian Looney, personal communication). There is a similar observation on a tree at the Lawrence Livermore National Laboratory (Mallon et al., 1991; Barbara Mallon, personal communication). Therefore, reduced uptake of groundwater and transpiration by trees at the SRS should be a major factor in the leveling of the reduction of tritium discharges into surface waters, from 1988-1990.

A linear model predicts continuing seepage migration from through 2004 (Section 5.3.5). A reduction in the quantity of tritium discharged annually from ground water to surface waters is expected as vegetation regrows at the SRS. This appears to be the situation in 1991 (Brian Looney, personal communication). In the future, some annual discharges to surface waters from old releases to ground water may occur even at lower rates than those predicted by the linear model. The discharges are still expected to continue to the year 2004. 
Table 5.17. Influence of a $40 \%$ Increase in Releasea on Statistics for Predicted 1993 Receptor Concentrations of Tritium (Scenario 3) with Comparisons to the USEPA Drinking Water Standard.

\begin{tabular}{|c|c|c|c|c|c|c|}
\hline \multirow[t]{2}{*}{ Receptor } & \multicolumn{2}{|c|}{$\begin{array}{l}\text { Water Concentration } \\
\qquad(\mathrm{pCi} / \mathrm{L})\end{array}$} & \multicolumn{2}{|c|}{$\begin{array}{c}\text { Total Annual Expcsure } \\
\text { (pCi) }\end{array}$} & \multicolumn{2}{|c|}{$\begin{array}{c}\text { Incremental Individual } \\
\text { Risk } \\
\text { (cancer mortality) }\end{array}$} \\
\hline & Average & Range & Average & Maximum & Average & $\uparrow 95 \%$ Limit \\
\hline $\begin{array}{l}\text { BJ or PW } \\
\text { Receptor }(+40 \%)^{a} \\
\text { EPA Standard }\end{array}$ & $\begin{array}{l}2230 \\
3850 \\
20000\end{array}$ & $\begin{array}{r}1360-2980 \\
6-10300\end{array}$ & $\begin{array}{l}8.8 \mathrm{E}+5 \\
1.6 \mathrm{E}+6 \\
8.6 \mathrm{E}+6\end{array}$ & $\begin{array}{l}1.9 E+7 \\
1.8 E+7 \\
7.7 E+7\end{array}$ & $\begin{array}{l}3.8 \mathrm{E}-8 \\
6.6 \mathrm{E}-8 \\
3.7 \mathrm{E}-7\end{array}$ & $\begin{array}{l}7.8 E-7 \\
7.7 E-7 \\
3.5 E-6\end{array}$ \\
\hline
\end{tabular}

Additional direct releases from separations and other nonreactor processes in 1990 brought the total release of tritium to surface waters to $1.65 \times 10^{4} \mathrm{Ci}$ (Cummins et al., 1991), or $40 \%$ above the predicted seepage contribution. A risk analysis for the year 1993 under Scenario 3, with or without a $40 \%$ addition to the seepage release to surface waters, yielded no appreciable difference in the average individual risk (Table 5.17). Since the highest IR in the three scenarios was obtained in 1993 , an additional $40 \%$ of the seepage release of tritium to surface water would not cause the IR in any other year to exceed the comparable calculated values for the EPA drinking water standard.

\section{Water Ingestion Exposure}

The largest exposure pathway, the amount of water ingested annually, is another source of uncertainty. The distribution of water ingestion is based on 1978 NRC data (Hamby, 1991, 1992) for the Southern United States. Calculations from a recent study (Ershow and Cantor, 1989) yielded an average intake rate in the South that is $130 \mathrm{~L}$ per year greater than our original estimate. A lognormal distribution (Roseberry and Burmaster, 1992) of this greater annual water intake, increased the average IR value by approximately $35 \%$ over the previous distribution (Table 5.18 ), while increasing both the upper $95 \%$ confidence level and the overall range of risks by $8 \%$.

Table 5.18. Influence of Greater Ratesa of Water Ingestion on Statistics for Predicted 1993 Receptor Concentrations of Tritium (Scenario 3).

\begin{tabular}{|c|c|c|c|c|c|c|}
\hline \multirow[t]{2}{*}{$\begin{array}{l}\text { Average Annual } \\
\text { Water Ingestion } \\
\left.\text { ( } \bigsqcup_{\mathrm{yr}}\right) \\
\end{array}$} & \multicolumn{2}{|c|}{$\begin{array}{c}\text { Water Concentration } \\
\text { (pCi/L) }\end{array}$} & \multicolumn{2}{|c|}{$\begin{array}{l}\text { Total Annual Exposure } \\
\qquad(\mathrm{pCi}) \\
\end{array}$} & \multicolumn{2}{|c|}{$\begin{array}{c}\text { Incremental Individual } \\
\text { Risk } \\
\text { (cancer mortality) } \\
\end{array}$} \\
\hline & Average & Range & Average & Maximum & Average & $\uparrow 95 \%$ Limit \\
\hline $\begin{array}{l}340 \\
470^{a}\end{array}$ & $\begin{array}{l}3850 \\
3850\end{array}$ & $\begin{array}{l}6-10300 \\
6-10300\end{array}$ & $\begin{array}{l}8.7 E+5 \\
1.2 E+6\end{array}$ & $\begin{array}{l}6.0 \mathrm{E}+6 \\
7.8 \mathrm{E}+6\end{array}$ & $\begin{array}{l}3.7 \mathrm{E}-8 \\
5.0 \mathrm{E}-8\end{array}$ & $\begin{array}{l}2.5 \mathrm{E}-7 \\
2.7 \mathrm{E}-7\end{array}$ \\
\hline
\end{tabular}

aBased upon a lognormal distribution of annual water ingestion rates (average, $470 \mathrm{~L} / \mathrm{yr}$; SD, 264 Lyr; range, 63-2710 Lyr) derived from Ershow and Cantor (1989) 


\section{HUMAN HEALTH RISK ASSESSMENT FOR ${ }^{137}$ Cs RELEASED TO THE SAVANNAH RIVER}

Figure 6.1. The Savannah River Site

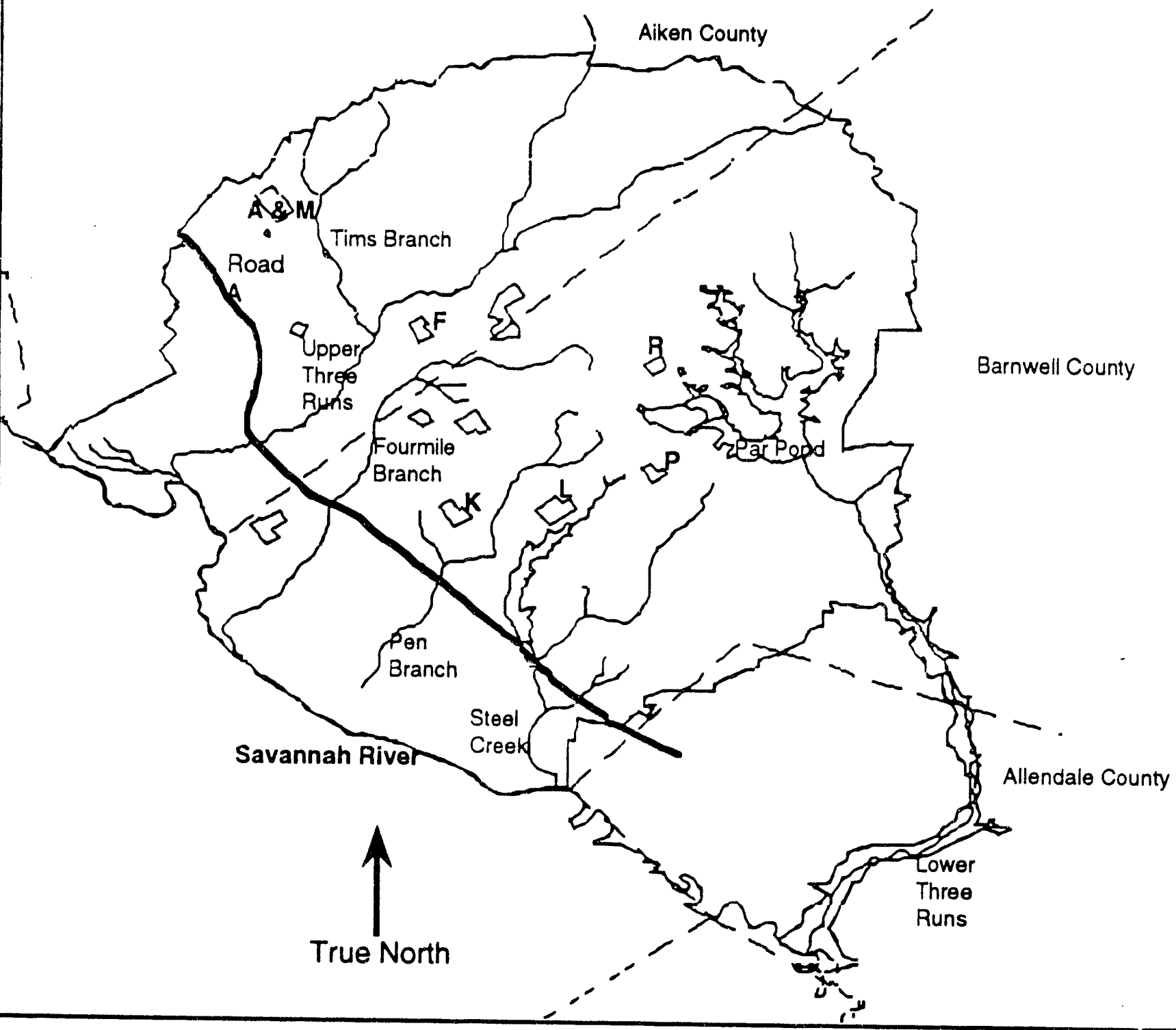

6.1 Major Steps in the Risk Assessment for ${ }^{137}$ Cs Released to the Savannah River.

The following six general steps were applied to the analyses of cancer mortality risks from ${ }^{137} \mathrm{Cs}$ : 
1. Define the problem (section 6.2);

2. Develop estimates of source terms and predict environmental ${ }^{137} \mathrm{Cs}$ concentrations (section 6.3);

3. Review information on transport and fate of ${ }^{137} \mathrm{Cs}$ in the Savannah River System (section 6.4);

4. Determine exposure pathways and estimate exposures (section 6.5);

5. Review dose-response information (section 6.6);

6. Estimate excess lifetime individual and population risks (section 6.7).

Monte Carlo analytical calculations were performed with values, or Latin Hypercube sampling of distributions of values, using Crystal Ball ${ }^{\circledR}$ software (Decisioneering Corp., Boulder, CO) in conjunction with spreadsheets constructed in Excel ${ }^{\circledR}$ (Microsoft Corp., Seattle, WA) on a Macintosh ${ }^{\circledR}$ computer (Apple Corp., Cupertino, CA).

\subsection{Problem Summary}

The reactor operations that release tritium to the Savannah River also release ${ }^{137} \mathrm{Cs}$. Only a portion of the ${ }^{137} \mathrm{Cs}$ is either in solution or forms part of the suspended particles in the water column. Sediments bind most of the released ${ }^{137} \mathrm{Cs}$ in surface water substrates, where it remains in equilibrium with the water column.

Life forms, including humans, readily take up and metabolize radioactive cesium ( ${ }^{137} \mathrm{Cs}$ ). It is concentrated within cells throughout the body in a manner similar to potassium. Although the quantity of ${ }^{137} \mathrm{Cs}$ released to the Savannah River is much lower than that of tritium, ${ }^{137} \mathrm{Cs}$ emits both $\beta$ and $\gamma$ radiation, with a half-life approximately 2.5 times that of tritium (tritium $=12.3$ years, ${ }^{137} \mathrm{Cs}=30.17$ years). Prolonged residence in the river sediment and longer radiological half-life make ${ }^{137} \mathrm{Cs}$ a potential health hazard for a longer term than would be expected for tritium. However, the major portion of the committed dose occurs during the year of intake because the turnover rate in the body (biological half-life) is so rapid.

\subsection{The Sources of ${ }^{137} \mathrm{Cs}$ at the SRS}

The Savannah River Site (SRS) has operated up to five reactors (see section 5.3.1) for producing weapons-grade tritium and plutonium by irradiating target materials. ${ }^{137} \mathrm{Cs}$ is one of the major byproducts of fission reactors. The most significant discharges of ${ }^{137} \mathrm{Cs}$ to the environment are dissolved and particulate ${ }^{137} \mathrm{Cs}$ in water. Cesium discharge originates from reactor operations and other sources. Sources from reactor operations consist of small leaks from primary. reactor cooling water into secondary cooling water that discharges to reactor seepage basins and surface waters. "Most of the ${ }^{137} \mathrm{Cs}$ [about $460 \mathrm{Ci}$...] originated from releases in the 1960 s from fuel storage facilities at the five production reactors operating at that time" (DOE, 1990). For the period 1955 to 1980, SRS operations released a total of approximately $560 \mathrm{Ci}$ of ${ }^{137} \mathrm{Cs}$ (USDOE, 1990). The major problems to be addressed in developing source terms for ${ }^{137} \mathrm{Cs}$ in Savannah River water are: 
1. To predict a distribution of annual amounts of ${ }^{137} \mathrm{Cs}$ to be released for transport in the river;

2. To predict a distribution of concentrations of ${ }^{137} \mathrm{Cs}$ in the river water as a result of varying volumes of annual Flow.

\subsubsection{Water Discharges from SRS Operations to Streams}

Discharges of secondary coolant water and groundwater flow to effluent streams from $K-, L_{-}, P_{\text {- }}$ and R-Reactor operations could potentially have affected the dissolved component of ${ }^{137} \mathrm{Cs}$ for Fourmile Branch, Pen Branch, Steel Creek, and Lower Three Runs Creek (Figure 6.1). No discharge (other than fallout load) of ${ }^{137} \mathrm{Cs}$ is to be expected into the Upper Three Runs discharge basin. In the future, only K-Reactor is expected to be in operation, with discharges going directly to surface water (see section 5.3.4).

\subsubsection{Role of Cesium Chemistry}

While reactor operations produce both tritium and ${ }^{137} \mathrm{Cs}$, the environmental behavior of the two radionuclides differs markedly. Tritium can, if its decay is ignored, be considered a "conservative" species. As a conservative species, changes in the concentration of tritium are primarily a consequence of dilution and mixing. ${ }^{137} \mathrm{Cs}$ is a decidedly reactive species for at least two reasons.

First, ${ }^{137} \mathrm{Cs}$ strongly associates with solid particles. If a given quantity of ${ }^{137} \mathrm{Cs}$ is put into a watersediment system, the overwhelming majority of the ${ }^{137} \mathrm{Cs}$ will be associated with the solid sediments. The affinity of ${ }^{137} \mathrm{Cs}$ for solids results from the relatively high charge density of the $\mathrm{Cs}^{+}$ cation, which, paradoxically is a consequence of its relatively large size. Other singly charged cations like $\mathrm{K}^{+}$and $\mathrm{Na}^{+}$are not as strongly sorbed to solid surfaces because they normally associate with a number of waters of hydration. The water molecules surrounding these cations dilute the ionic charges over a large surface area. $\mathrm{Cs}^{+}$is not hydrated and has a relatively higher charge to surface area ratio.

Second, $\mathrm{Cs}$ is similar to $\mathrm{K}$ in its chemical behavior. Potassium is an essential element to plant and animal growth, and is commonly in limited, if not limiting, supply. Ions of both elements are actively taken up by living cells. Therefore, $\mathrm{Cs}$ tends to be more concentrated in tissues of living organisms than in fresh water.

The affinity of $\mathrm{Cs}$ for surfaces under normal environmental conditions can explain why routine measurements of ${ }^{137} \mathrm{Cs}$ in SRS stream waters regularly fail to detect this radionuclide. Fourmile Branch is an example in which there are known releases of ${ }^{137} \mathrm{Cs}$ from plant operations and some relatively high levels of ${ }^{137} \mathrm{Cs}$ have been measured in the stream sediment and soil along its banks. Evidently, a major fraction of the ${ }^{137} \mathrm{Cs}$ emanating from plant operations is quickly adsorbed by stream sediments without being transported offsite. SRS uses a much more sensitive technique for measuring low levels of ${ }^{137} \mathrm{Cs}$ in Savannah River water than is used for measuring in SRS stream waters. As a consequence most dissolved ${ }^{137} \mathrm{Cs}$ in SRS streams goes undetected and is reported as below detection limits. 


\subsection{3 ${ }^{137}$ Cs Delivery to the Savannah River}

Only a very small fraction of the ${ }^{137} \mathrm{Cs}$ burden of SRS streams leaves SRS in dissolved form. Because of the chemical behavior of cesium, as discussed above, most of the ${ }^{137} \mathrm{Cs}$ delivered to SRS streams remains associated with solid particles. The loss of ${ }^{137} \mathrm{Cs}$ from SRS is primarily by radioactive decay and transport of stream bed load from SRS to the Savannah River through resuspension. Although we use the term "resuspension" ior this quantity (as does SRS), some fraction of this "resuspended" material is likely to be in solution. USDOE (1990) estimated that the annual ${ }^{137} \mathrm{Cs}$ resuspended from SRS streams and delivered to the Savannah River averages 0.51 $\mathrm{Ci}(S D=0.13)$, based upon back-calculations from concentration data for 1983 through 1988 . For each year, the annual average concentration in the Savannah river that comes from the Savannah River Site (SRS) was calculated by

$$
\left[{ }^{137} C S\right]_{S R S}=\left[{ }^{137} C s\right]_{R-10}-\left[{ }^{137} C s\right]_{R-2}
$$

when:

$\left[{ }^{137} \mathrm{Cs}\right]=$ concentration of ${ }^{137} \mathrm{Cs}(\mathrm{pCi} / \mathrm{L})$;

R10 = annual average of measurements downriver from the SRS, at Highway 301(Table 6.1);

$\mathrm{R} 2$ = annual average of measurements upriver from the SRS tributaries, at Shell Bluff (Table 6.1).

The total quantity of ${ }^{137} \mathrm{Cs}$ mobilized from the SRS to the River each year (Table 6.1) was calculated by multiplying the $\left[{ }^{137} \mathrm{Cs}\right]$ SRS by the respective river flow $\left(V_{\text {нон }}\right.$; Table 2$)$ :

$$
{ }^{137} C s(C i)={ }^{137} C s\left(\frac{p C i}{L}\right) \times \frac{10^{-3} C i}{p C i} \times V_{H O H}(L)
$$

Table 6.1. Average Annual Measured Concentrations ( $\mathrm{pCi} / \mathrm{L}$ ) of ${ }^{137} \mathrm{Cs}$ in the Savannah River ${ }^{\mathrm{a}}$ and

\begin{tabular}{|c|c|c|c|c|c|c|c|}
\hline \multirow[b]{2}{*}{ Year } & \multirow{2}{*}{\multicolumn{2}{|c|}{$\begin{array}{c}{ }^{137} \text { Cs Released } \\
\text { from SRS } \\
\text { (Ci) }\end{array}$}} & \multicolumn{5}{|c|}{$\begin{array}{l}\text { Ultra Low-Level } \\
\text { Measurements }\end{array}$} \\
\hline & & & $\begin{array}{l}\text { N. Augusta, } \\
\text { raw }^{c}\end{array}$ & $\begin{array}{l}\text { Shell Bluff } \\
(\mathrm{A}-2)\end{array}$ & $\begin{array}{c}\text { Highway } \\
301 \quad(\mathrm{R}-10)\end{array}$ & $\begin{array}{l}\text { Beaufort- } \\
\text { Jasper, raw }\end{array}$ & $\begin{array}{c}\text { Port Wentworth, } \\
\operatorname{raw}^{c}\end{array}$ \\
\hline & & Mile $\rightarrow$ & 206 & 160 & 120 & 39 & 29 \\
\hline & & $\mathrm{Km} \rightarrow$ & 332 & 258 & 193 & 63 & 47 \\
\hline 1983 & 0.64 & & $9.00 \mathrm{E}-03$ & $1.60 \mathrm{E}-02$ & $6.70 \mathrm{E}-02$ & $4.20 \mathrm{E}-02$ & $4.50 \mathrm{E}-02$ \\
\hline 1984 & 0.58 & & $5.00 \mathrm{E}-03$ & $1.20 E-02$ & $6.40 E-02$ & $3.10 E-02$ & $3.20 E-02$ \\
\hline 1985 & 0.52 & & $4.00 E-03$ & $1.50 E-02$ & $7.70 E-02$ & $4.30 E-02$ & $4.90 E-02$ \\
\hline 1986 & 0.58 & & $8.00 E-03$ & $2.10 E-02$ & $1.14 E-01$ & 6.30 E-02 & $6.40 E-02$ \\
\hline 1987 & 0.48 & & & $1.00 E-02$ & 7.40 E- 02 & & \\
\hline 1988 & 0.27 & & & $1.40 E-02$ & $6.50 E-02$ & & \\
\hline 1989 & 0.33 & & & $1.20 E-02$ & $5.80 \mathrm{E}-02$ & & \\
\hline 1990 & 0.22 & & & $8.80 E-03$ & $2.80 E-02$ & & \\
\hline
\end{tabular}
Calculated Annual Releases from the SRS. (Distances are measured from the mouth of the river.)

aCummins, et al., 1990, 1991; Mikol, et al., 1988; and Zeigler, et al., 1986

bCalculated as described in Table 4-11 in DOE, 1990

'No data available for the raw drinking water supplies after 1986. 
Table 6.2. Annual Flow in the Savannah Rivera.

\begin{tabular}{|cc|}
\hline Year & Volume (L) \\
\hline 1954 & $7.1634 E+12$ \\
1955 & $5.3899 E+12$ \\
1956 & $5.3024 E+12$ \\
1957 & $6.4553 E+12$ \\
1958 & $1.1162 E+13$ \\
1959 & $6.9991 E+12$ \\
1960 & $1.2227 E+13$ \\
1961 & $8.7154 E+12$ \\
1962 & $9.1118 E+12$ \\
1963 & $9.3842 E+12$ \\
1964 & $1.6287 E+13$ \\
1965 & $1.2709 E+13$ \\
1966 & $9.3404 E+12$ \\
1967 & $8.2233 E+12$ \\
1968 & $8.8823 E+12$ \\
1969 & $9.6378 E+12$ \\
1970 & $6.9071 E+12$ \\
1971 & $8.5144 E+12$ \\
1972 & $1.0056 E+13$ \\
1973 & $1.2967 E+13$ \\
1974 & $9.6476 E+12$ \\
1975 & $1.198 E+13$ \\
1976 & $1.1889 E+13$ \\
1977 & $1.084 E+13$ \\
1978 & $1.0093 E+13$ \\
1979 & $1.0581 E+13$ \\
1980 & $1.2331 E+13$ \\
1981 & $6.1659 E+12$ \\
1982 & $6.7964 E+12$ \\
1983 & $1.0864 E+13$ \\
1984 & $1.1245 E+13$ \\
1985 & $6.3097 E+12$ \\
1986 & $6.1115 E+12$ \\
1987 & $1.0145 E+13$ \\
1988 & $5.0595 E+12$ \\
1989 & $6.9919 E+12$ \\
1990 & $1.0773 E+13$ \\
-- & - \\
\hline Mean & $9.2772 E+12$ \\
SD & $2.5783 E+12$ \\
\hline
\end{tabular}

aData derived from Cummins et al., 1990;

Murphy et al., 1991

1 distribution was determined for all the years in question. When data from special low-level neasurements for 1989 and 1990 were included (Table 6.1), an estimated overall average of 0.45 i $(S D= \pm 0.16)$ of ${ }^{137} \mathrm{Cs}$ was delivered annually to the Savannah River. This estimated annual 
release is conservatively high because it includes data from operations of $K, L$, and $P$ reactors prior to 1989. An assumed lognormal distribution yields an average annual release of $0.42 \mathrm{Ci}$.

To predict the $\left[{ }^{137} \mathrm{Cs}\right]$ at Highway 301 (R-10) that result from SRS releases, the values for the distribution of the estimated delivery of $\mathrm{Ci}$ to the river (from equation 35) must be divided by the normal distribution of annual river flows ( $V$ in liters, Table 6.2) into:

$$
R 10\left[{ }^{137} C s\right]_{\text {predicted }}=\frac{{ }^{137} \mathrm{Cs}(\mathrm{Ci})}{V(L)} \times \frac{10^{12} \mathrm{pCi}}{\mathrm{Ci}}
$$

The predicted $\left[{ }^{137} \mathrm{Cs}\right.$ ]R-10 ranges from $1.4 \mathrm{E}-2$ to $1.2 \mathrm{E}-1$ pCi L-1 (average $=4.6 \mathrm{E}-2 \mathrm{pCi} \mathrm{L}{ }^{-1}$; $\mathrm{SD}=1.6 \mathrm{E}-2$ ).

\subsection{Transport of ${ }^{137} \mathrm{Cs}$ in the Savannah River}

Figure 6.2. Average Concentrations of ${ }^{137} \mathrm{Cs}$ in Water Along the Savannah River from 1983 through 1986 (calculated from data in Cummins et al., 1990, 1991; Davis et al., 1989; Mikol et al., 1988; and Zeigler et al., 1987; error bars $= \pm 1$ SD).

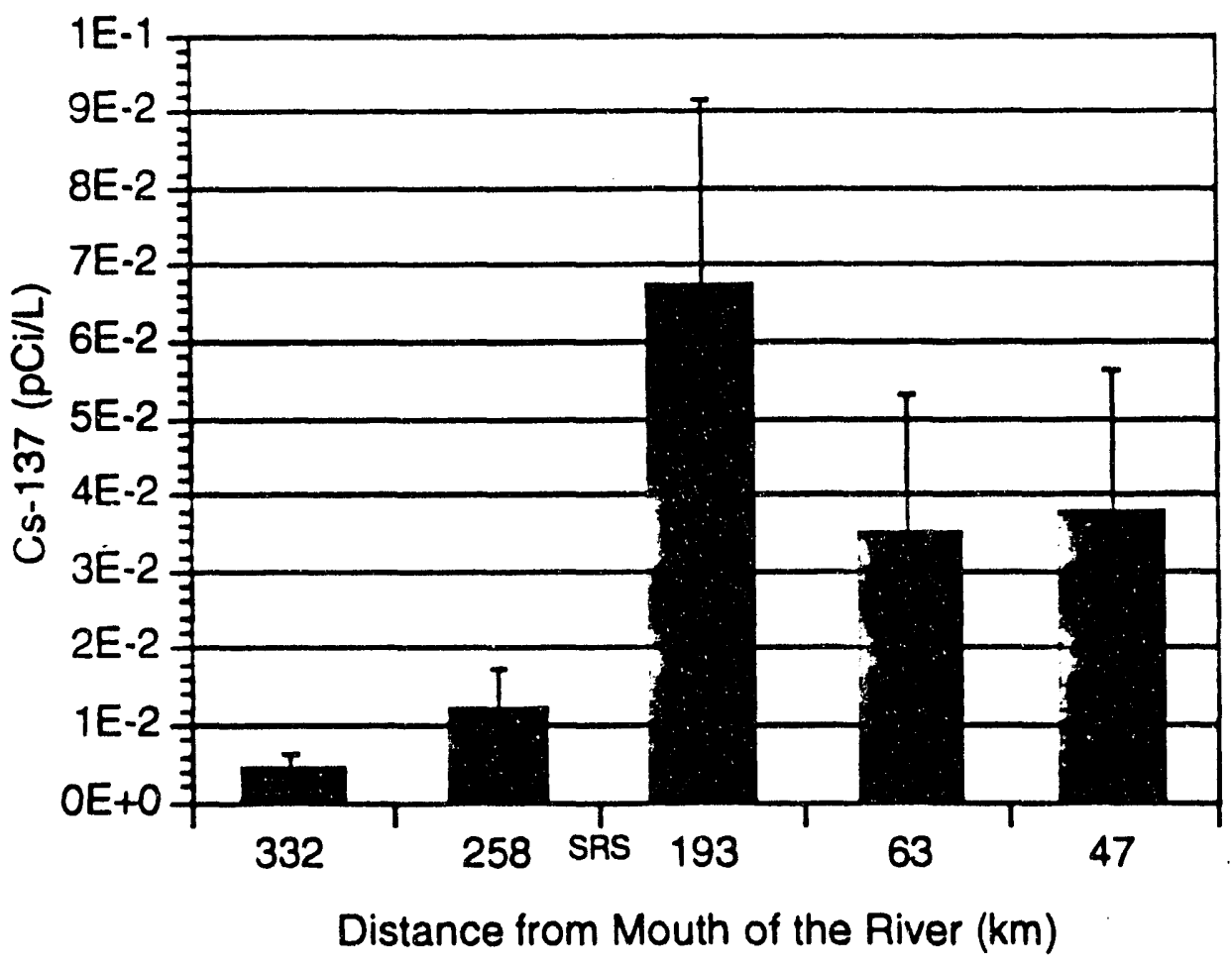

The total quantity of ${ }^{137} \mathrm{Cs}$ downstream from SRS includes: ${ }^{137} \mathrm{Cs}$ that arrives at SRS from upriver; and ${ }^{137} \mathrm{Cs}$ delivered to the Savannah River from SRS operations and other sources within the Savannah River basin. If dissolved Cs behaved conservatively, the concentration ([ $\left.\left.{ }^{137} \mathrm{Cs}\right]\right)$ in Savannah River water would depend on this total quantity, the volume of the Savannah River before it arrives at the SRS, and any net changes in volume downstream. In reality, the $\left[{ }^{137} \mathrm{Cs}\right]$ in Savannah River Water (Figure, 6.2) is not directly related to the production of ${ }^{137} \mathrm{Cs}$ reported by the SRS. This is true whether one looks at the absolute $\left[{ }^{137} \mathrm{Cs}\right]$ or the difference between the values above and below the plant. This lack of correlation between the concentration of ${ }^{137} \mathrm{Cs}$ in the 
Savannah River and the production of ${ }^{137} \mathrm{Cs}$ could be due to many different processes. The probable cause for the lack of correlation is that the strong adsorption of ${ }^{137} \mathrm{Cs}$ to the sediment, as previously discussed, keeps the radionuclide from dissolving in the water.

SRS streams carry dissolved and particulate ${ }^{137} \mathrm{Cs}$ to the Savannah River, where it joins ${ }^{137} \mathrm{Cs}$ from other other sources (e.g., atmospheric deposition) in the river. Part of the ${ }^{137}$ Cs sequesters in the sediments along the course of the river. Table 6.3 shows average annual concentrations of ${ }^{137} \mathrm{Cs}$ in Savannah River sediments for the period 1983-1990.

Table 6.3. Annual Arithmetic Average Concentrations (pCi/g) of ${ }^{137} \mathrm{Cs}$ in Sediments Along the Savannah River. ${ }^{a, b}$

Location

\begin{tabular}{|c|c|cccccccc|} 
Mile & $\mathrm{Km}$ & 1983 & 1984 & 1985 & 1986 & 1987 & 1988 & 1989 & 1990 \\
\hline 161 & 258 & 0.13 & 0.21 & 0.12 & 0.10 & 0.18 & 0.00 & 0.06 & 0.17 \\
137 & 220 & 0.25 & 0.32 & 0.84 & 0.37 & 0.43 & 0.25 & 0.62 & 0.67 \\
134 & 216 & 0.39 & & & 0.36 & 0.42 & 0.07 & 0.30 & $1.20 !$ \\
130 & 209 & 0.64 & 0.32 & 0.76 & 0.21 & 0.62 & 0.74 & 0.94 & 1.10 \\
119 & 191 & 0.50 & & 1.00 & 0.99 & 0.57 & 0.29 & 0.72 & 0.34 \\
\hline
\end{tabular}

Demier's Landing

Above Little Hell Landing

Below Little Hell Landing

Above Lower Three Runs

Highway 301

aCummins et al., 1990, 1991;

Raw drinking water concentrations of ${ }^{137} \mathrm{Cs}$ at the two receptors sites, Beaufort-Jasper and Port Wentworth, were predicted in two steps. First, a dilution factor (DF) distribution was calculated by averaging the ratio of the measured raw concentration at each receptor site to the measured concentration at Highway 301 (R10), for the years 1983 through 1986 (Table 6.4):

$$
D F_{\text {receptor }}=\text { Average }\left(\frac{\left[{ }^{137} C s\right]_{\text {receptor }}}{\left[{ }^{137} C s\right]_{R-10}}\right)_{1983-1986}
$$

Combining results for $\mathrm{BJ}$ and PW yields a distribution with an average DF of $0.57(S D=0.07)$.

Table 6.4. Derivation of Dilution Factors (DF) from Measurement Averages of [ ${ }^{137} \mathrm{Cs}$ ] for Raw Water at the Beaufort-Jasper (BJ) and Port Wentworth (PW) Water Purification Facilities.

\begin{tabular}{|c|c|c|c|c|c|}
\hline & R10 & $B U_{\text {raw }}$ & \multicolumn{3}{|c|}{$P W_{\text {raw }}$} \\
\hline Year & $\mathrm{pCi} / \mathrm{L}$ & $\mathrm{pCin}$ & BJ:R10 & $\mathrm{pCill}$ & PW:R10 \\
\hline 1983 & 0.067 & 0.042 & 0.63 & 0.045 & 0.67 \\
\hline $\begin{array}{l}1984 \\
1985\end{array}$ & $\begin{array}{l}0.064 \\
0.077\end{array}$ & $\begin{array}{l}0.031 \\
0.043\end{array}$ & $\begin{array}{l}0.48 \\
0.56\end{array}$ & $\begin{array}{l}0.032 \\
0.049\end{array}$ & $\begin{array}{l}0.50 \\
0.64\end{array}$ \\
\hline $\begin{array}{l}1985 \\
1986\end{array}$ & $\begin{array}{l}0.077 \\
0.114\end{array}$ & $\begin{array}{l}0.043 \\
0.063\end{array}$ & $\begin{array}{l}0.56 \\
0.55\end{array}$ & $\begin{array}{l}0.049 \\
0.064\end{array}$ & $\begin{array}{l}0.64 \\
0.56\end{array}$ \\
\hline DF & & $\begin{array}{c}\text { Average } \\
\text { SD }\end{array}$ & $\begin{array}{l}0.56 \\
0.06\end{array}$ & & $\begin{array}{l}0.59 \\
0.08\end{array}$ \\
\hline
\end{tabular}


Second, samples from the distribution of the dilution factor for each receptor site (Table 6.4) were multiplied by the distribution of ${ }^{137} \mathrm{Cs}$ concentrations at Highway 301 (from equation 36) to calculate distributions of concentrations in the raw drinking water (Table 6.5):

$$
\operatorname{Raw}\left[{ }^{137} \mathrm{Cs}\right]_{\text {receptor }}=\operatorname{Pr} \text { edicted }\left[{ }^{137} C s\right]_{R-10} * D F_{\text {recepror }}
$$

Table 6.5. Predicted Raw Water $\left[{ }^{137} \mathrm{Cs}\right](\mathrm{pCl} / \mathrm{L})$ at the Beaufort-Jasper $(\mathrm{BJ})$ and Port Wentworth (PW) Water Purification Facilities.

\begin{tabular}{|ccc|}
\hline & $\mathrm{BJ}$ & $\mathrm{PW}$ \\
\cline { 2 - 3 } Arithmetic Average & $2.6 \mathrm{E}-2$ & $2.7 \mathrm{E}-2$ \\
SD & $9.4 \mathrm{E}-3$ & $1.0 \mathrm{E}-2$ \\
Minimum & $7.2 \mathrm{E}-3$ & $8.0 \mathrm{E}-3$ \\
Maximum & $7.6 \mathrm{E}-2$ & $7.7 \mathrm{E}-2$ \\
\hline
\end{tabular}

\subsection{Exposure Estimates}

\subsection{1 ${ }^{137}$ Cs Exposure Pathways}

Two potential pathways for ${ }^{137} \mathrm{Cs}$ are drinking water, for which the Savannah River serves as a raw water supply, and the consumption of fish from the Savannah River. Low concentrations of ${ }^{137} \mathrm{Cs}$ in the finished water from the two drinking water purification plants, combined with low transfer efficiencies, yield negligible exposures for the inhalation and dermal pathways. Atmospheric production of ${ }^{137} \mathrm{Cs}$ originating from SRS has a negligible impact on the receptors (DOE, 1990), and low concentrations of dissolved and particulate ${ }^{137} \mathrm{Cs}$ in drinking water further preclude any concern for dermal exposure to gamma-radiation.

\subsubsection{Drinking Water}

Savannah River water is used as the raw supply for the drinking water purification plants at Beaufort-Jasper and Port Wentworth. Together, these communities extract 2.2 to $2.3 \mathrm{~m}^{3} / \mathrm{s}$ of water from the Savannah River (L. Smith, personal communication, 1991). Concentrations of ${ }^{137} \mathrm{Cs}$ in the finished product of these plants are below the concentrations in the raw river water because the water is treated by coagulation. Different percentages of the radionuclide are removed at the two facilities because of differences in the processing methods used. In the period from 1984 to 1985, the Beaufort-Jasper water purification plant altered their processes, resulting in an increased efficiency of ${ }^{137} \mathrm{Cs}$ removal. Processing of drinking water by both plants removes an average $57 \%$ of the dissolved ${ }^{137} \mathrm{Cs}$ at Beaufort-Jasper and $21 \%$ at Port Wentworth. 
Table 6.6. Derivation of Removal Factors (RF) from Measurement Averages of $\left[{ }^{137} \mathrm{Cs}\right.$ ], for Drinking Water at the Beaufor-Jasper (BJ) and Port Wentworth (PW) Facilities.

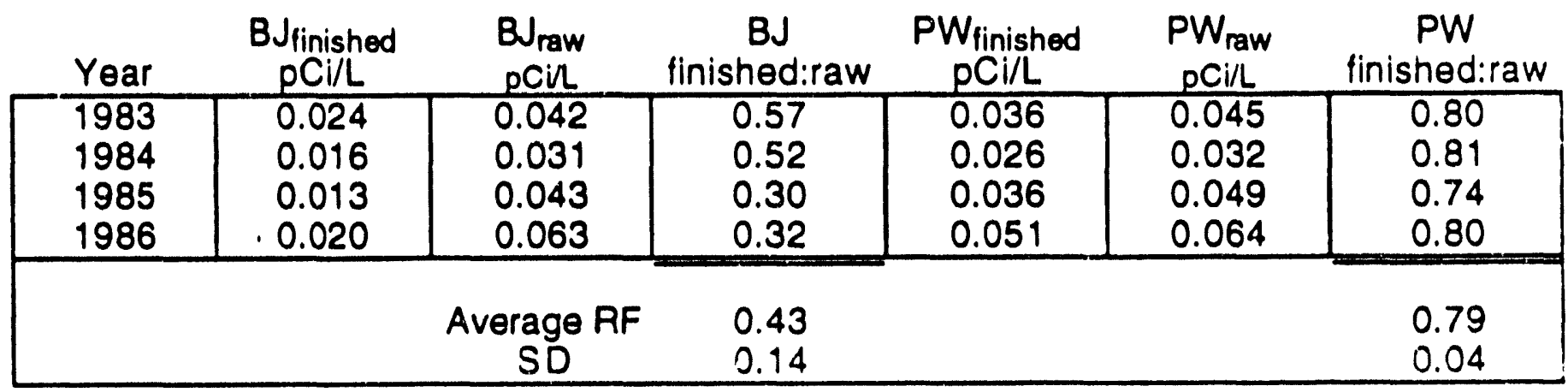

A removal factor (RF) distribution for each plant was obtained by averaging the respective ratios of finished to raw drinking water concentrations of ${ }^{137} \mathrm{Cs}$ (Table 6.6). To obtain the distributions of finished water concentrations of ${ }^{137} \mathrm{Cs}$ (Table 6.7), the samples from each distribution of raw water concentrations (Table 6.5) was multiplied by its respective RF:

$$
\text { Finished }\left[{ }^{137} C s\right]_{\text {receptor }}=\operatorname{Raw}\left[{ }^{137} C s\right]_{\text {recepor }} \times R F_{\text {receppor }}
$$

Table 6.7. Predicted Finished Water $\left[{ }^{137} \mathrm{Cs}\right](\mathrm{pCi} / \mathrm{L})$ at the Beaufort-Jasper (BJ) and Port Wentworth (PW) Water Purification Plants.

\begin{tabular}{|ccc|}
\hline & $\mathrm{BJ}$ & $\mathrm{PW}$ \\
\cline { 2 - 3 } Arithmetic Average & $1.1 \mathrm{E}-2$ & $2.2 \mathrm{E}-2$ \\
SD & $4.6 \mathrm{E}-3$ & $1.0 \mathrm{E}-2$ \\
Minimum & $2.8 \mathrm{E}-3$ & $6.4 \mathrm{E}-3$ \\
Maximum & $4.0 \mathrm{E}-2$ & $6.0 \mathrm{E}-2$ \\
\hline
\end{tabular}

The Environmental Protection Agency's current drinking water standard (EPA, 1977) for ${ }^{137} \mathrm{Cs}$ is $200 \mathrm{pCi} / \mathrm{L}\left(2.0 \times 10^{-7} \mathrm{Ci} / \mathrm{ml}\right)$. The predicted concentrations of ${ }^{137} \mathrm{Cs}$ in finished water at the two water purification plants (Table 6.7) are at least four orders of magnitude lower than the current EPA drinking water standard, and three to four orders of magnitude lower than a recently proposed standard of $119 \mathrm{pCil}$ (USEPA, 1991).

Table 6.8. Predicted Annual Intakes of ${ }^{137} \mathrm{Cs}$ (pCi) in Drinking Water from the Beaufort-Jasper (BJ) and Port Wentworth (PW) Water Processing Plants.

\begin{tabular}{|crc|}
\hline & BJ & PW \\
\cline { 2 - 3 } Average & 3.8 & 7.3 \\
SD & 2.0 & 3.5 \\
Minimum & 0.6 & 1.1 \\
Maximum & 18.4 & 31.1 \\
\hline
\end{tabular}

Annual Exposure (WIE) from drinking water (Table 6.8) at each receptor was calculated by multiplying the predicted finished water concentration of ${ }^{137} \mathrm{Cs}$ by samples from the lognormally distributed annual water intake (WI from Table 5.6: Average, $340 \mathrm{~L} / \mathrm{yr} ; \mathrm{SD}, 105 \mathrm{~L} / \mathrm{r}$; calculated in section 5.5.1): 


$$
W I E=W\left(\frac{L}{y r}\right) \times 1 y r \times \text { Finished }\left[{ }^{137} C s\right]_{\text {rocepor }}\left(\frac{p C i}{L}\right)
$$

\subsubsection{Fish Consumption}

Table 6.9 shows the ${ }^{137} \mathrm{Cs}$ concentrations in Savannah River water and in whole fish collected above and below the SRS. It was evident from the data in Table 6.7 that fish bioconcentrate ${ }^{137} \mathrm{Cs}$ when tissue measurements when tissue measurements were compared to those for Savannah River water. In order to predict human exposure to ${ }^{137} \mathrm{Cs}$ in ingested fish, the first step was to develop a bioconcentration factor (BCF) for the edible portions of fishes from the Savannah River.

$$
B C F=\frac{\left[{ }^{137} C s\right]_{f u h}}{\left[{ }^{137} C s\right]_{\text {mater }}} \times C F=\frac{\frac{p C i}{k g}}{\frac{p C i}{L}} \times \frac{1 L}{k g}
$$

$\mathrm{CF}=$ conversion factor for water $\left(1 \mathrm{~L} \cdot \mathrm{kg}^{-1}\right)$

Table 6.9. Bioconcentration Factors (BCF) for ${ }^{137} \mathrm{Cs}$ in Whole Fish Taken from the Savannah River, Above and Below the Savannah River Site (SRS)a.

\begin{tabular}{|c|c|c|c|c|c|c|}
\hline & $\begin{array}{c}\text { Fish Above } \\
\text { SRS } \\
\text { (pCi/kg) }\end{array}$ & $\begin{array}{c}\text { R2 } \\
\text { Waterb } \\
\text { (pCi/L) }\end{array}$ & $\begin{array}{c}\text { BCF } \\
\text { Above } \\
\text { SRS }\end{array}$ & $\begin{array}{c}\text { Fish Below } \\
\text { SRS } \\
\text { (pCi/kg) }\end{array}$ & $\begin{array}{c}\text { R10 } \\
\text { Waterb } \\
\text { (pCi/L) }\end{array}$ & $\begin{array}{c}\text { BCF } \\
\text { Below } \\
\text { SRS }\end{array}$ \\
\hline 1983 & 140 & .016 & 8750 & 80 & .067 & 1194 \\
1984 & 110 & .012 & 9167 & 60 & .064 & 938 \\
1985 & 10 & .015 & 667 & 10 & .077 & 130 \\
1986 & 120 & .021 & 5714 & 380 & .114 & 3333 \\
1987 & 170 & .010 & 17000 & 190 & .074 & 2568 \\
1988 & 180 & .014 & 12857 & 420 & .065 & 6462 \\
1989 & 60 & .012 & 5000 & 190 & .058 & 3276 \\
1990 & 110 & .009 & 12500 & 100 & .028 & 3571 \\
\hline
\end{tabular}

aData averages obtained from Cummins et al., 1991.

bSpecial low level measurements corresponding to above (R2) and below (R10) the SRS.

The most reliable data available were special ultra low-level measurements of ${ }^{137} \mathrm{Cs}$ concentrations in the water and the corresponding concentrations in fish, above and below the SRS during the years 1983 through 1990 (Table 6.9). A distribution of BCFs (Average, 5800, SD, 5000) was obtained from the combined upstream and downstream data (equation 41).

Although sensitive measurements of the concentrations of ${ }^{137} \mathrm{Cs}$ the river water were made at the two receptor sites from 1983 through 1986, there were no corresponding fish data available for those years (Mikol et al., 1988). Based on the calculations of ${ }^{137} \mathrm{Cs}$ concentrations in raw drinking water (Table 6.6), an assumed lognormal distribution of the BCFs, derived from the combined data above and below the SRS, approximated the distribution of BCFs for fish at the level of the two 
downriver receptors. The calculated average, 3400, is in good agreement with the published sitespecific BCF of 3000 for SRS (Hamby, 1992).

Table 6.10. Predicted Annual Exposures to ${ }^{137} \mathrm{Cs}$ by Ingestion of Finfish from the Savannah River.

\begin{tabular}{|cc|}
\hline & $\mathrm{pCi}^{137} \mathrm{Cs}$ \\
\cline { 2 - 2 } Arithmetic Average & $6.9 \mathrm{E}+1$ \\
SD & $1.6 \mathrm{E}+2$ \\
Minimum & $6.1 \mathrm{E}-2$ \\
Maximum & $4.3 \mathrm{E}+3$ \\
\hline
\end{tabular}

Annual exposures (Table 6.10) from ingesting finfish (FIE) were estimated by multiplying values from the distribution of: the predicted R10 concentration of ${ }^{137} \mathrm{Cs}$; the combined DF distribution (section 6.4); the BCF; and the lognormally distributed annual intake of finfish (FI, Table 5.7: Average, $7.7 \mathrm{~kg} / \mathrm{yr} ; \mathrm{SD}, 2.85 \mathrm{~kg} / \mathrm{yr}$ ) calculated in section 5.5.1:

$$
F I E(p C i)=R 10\left[1{ }^{137} C S\right]_{\text {predicted }}\left(\frac{p C i}{L}\right) \times D F_{\text {combined }} \times B C F \times F I\left(\frac{k g}{y r}\right) \times C F\left(\frac{1 L}{k g}\right) \times 1 y r
$$

\subsubsection{Total Annual Exposure (TAE)}

Total Annual Exposure (Table 6.11) is the sum of WIE (equation 40) and FIE (equation 42).

Table 6.11. Predicted Total Annual Exposures ( $\mathrm{pCi}$ ) to ${ }^{137} \mathrm{Cs}$ by Drinking Water and Ingestion of Finfish from the Savannah River.

\begin{tabular}{|ccc|}
\hline & $\mathrm{BJ}$ & $\mathrm{PW}$ \\
\cline { 2 - 3 } Arithmetic Average & $7.3 \mathrm{E}+1$ & $8.0 \mathrm{E}+1$ \\
SD & $1.6 \mathrm{E}+2$ & $1.7 \mathrm{E}+2$ \\
Minimum & $1.4 \mathrm{E}+0$ & $2.3 \mathrm{E}+0$ \\
Maximum & $4.3 \mathrm{E}+3$ & $4.2 \mathrm{E}+3$ \\
\hline
\end{tabular}

\subsection{Risk Characterization: Cancer Mortality}

${ }^{137}$ Cs readily distributes throughout the intracellular compartments of the body. Internal exposure yields a whole-body dose that is reiated to body size. Although $B$ emissions yield about the same dose in children and adults, gamma-photon energy escapes more readily from infants and children. Elimination (Biological) half-times are also shorter in infants, children and special classes of adults (e.g., pregnant women, cases of muscle-wasting diseases) than in ordinary adults. Therefore whole-body dose is inversely related to age, on the basis of changing body mass (NCRP 52, 1977). 


\subsubsection{Dose from Chronic Exposures to ${ }^{137}$ Cs (Sun et al., 1991)}

Age-specific effective doses (ED) through age 70 are provided in Table 8.-3 in ICRP-56 (1990) for ingested ${ }^{137} \mathrm{Cs}$. Dose calculations for all age groups in the current analyses are based on a conservative ED of $1.4 \times 10^{-8} \mathrm{~Sv}^{-\mathrm{Bq}^{-1}}$ for age 15 . The difference from the lowest ED, $9.0 \times 10^{-9}$ Sv•Bq-1 for age 5 , is $5.0 \times 10^{-9} \mathrm{~Sv}^{\circ} \mathrm{Bq}^{-1}$. Ninety per cent of the ED is received during the first year of exposure, based upon the retention function in ICRP-30 (1978), and chronic uptake yields an annual dose that is 2.8 times greater than the annual dose from an acute uptake. Therefore, the annual effective dose (AED) is calculated as follows:

$$
A E D=\frac{1.4 \times 10^{-8} S v}{B q}(0.9 \times 2.8)(B q \text { Exposure })=\frac{3.53 \times 10^{-8} S v}{B q}(\text { BqExposure })
$$

By definition there are $3.7 \times 10^{10} \mathrm{~Bq}^{\cdot} \mathrm{Ci}^{-1}=3.7 \times 10^{-2} \mathrm{~Bq}^{\cdot} \mathrm{pCi}^{-1}$. For low LET radiation $1 \mathrm{~Gy}=1 \mathrm{~Sv}$. By substitution in equation (43):

$$
A E D=\frac{3.53 \times 10^{-8} G y}{B q} \times \frac{3.7 \times 10^{-2} B q}{p C i}=\frac{1.3 \times 10^{-9} G y}{p C i}
$$

The maximum individual effective dose resulting from annual remobilization of ${ }^{137} \mathrm{Cs}$ from the $\mathrm{K}$ Reactor discharges was calculated to be $1.1 \times 10^{-2} \mathrm{mrem}$ at Beaufort-Jasper and Port Wentworth (page 4-32 and Table 4-12 in DOE, 1990). In the current analysis, an average TAE of 85 pCi for the two receptor populations (see table 6.13) yielded an ED of $1.1 \times 10^{-2} \mathrm{mrem}$.

The risk coefficient for cancer fatality from ${ }^{137} \mathrm{Cs}$ is 0.05 death per Gy (ICRP-60, 1991). Therefore, a factor for incremental individual lifetime cancer mortality risk (RC) was calculated as follows:

$$
R C=\frac{0.05 \text { deaths }}{G y} \times \frac{1.3 \times 10^{-9} G y}{p C i}=\frac{6.6 \times 10^{-11} \text { deaths }}{p C i}
$$

\subsubsection{Incremental Individual Risk (IR) for Cancer Mortality}

Table 6.12. Incremental Individual Cancer Mortality Risks (IR) from Ingestion of ${ }^{137} \mathrm{Cs}$ in Savannah River Fish and in Drinking Water from either the Beaufort-Jasper (BJ) or the Port Wentworth (PW)

Facilities.

\begin{tabular}{|ccc|}
\hline Arithmetic Average & IRBd & IREW \\
SD & $2.0 \mathrm{E}-9$ & $2.2 \mathrm{E}-9$ \\
Upper $95 \%$ Confidence Limit & $4.4 \mathrm{E}-9$ & $4.7 \mathrm{E}-9$ \\
\hline
\end{tabular}

The IRs (Table 6.12) from exposures to ${ }^{137} \mathrm{Cs}$ were calculated by multiplying the total annual exposure (TAE, pCi) by the RC obtained from equation (45). 


\subsubsection{The Population Risk (PR) for a Receptor Population}

The PR for a receptor population of size $\mathrm{N}$ was calculated by:

$$
P R=N \times T A E \times R C
$$

where, PR is the incremental number of cancer deaths in a population of size $\mathrm{N}$.

Table 6.13. Incremental Population Cancer Deaths from Annual Exposures to ${ }^{137} \mathrm{Cs}$ in Drinking Water at the Beaufort-Jasper (BJ) and Port Wentworth (PW) Facilities and in Savannah River Fish: Upper $95 \%$ Confidence Limits.

\begin{tabular}{|ccc|}
\hline & BJ & PW \\
Deaths & 0.0002 & 0.0004 \\
\hline
\end{tabular}

First level screening results in Table 6.13 are overconservative because they are the upper $95 \%$ iesult for a maximum population for each receptor $\left(N_{B J}=117,000 ; \mathrm{NPW}=200,000\right)$ in equation (46). Nevertheless, no detectable excess deaths are found in either population.

\subsubsection{Cesium in SRS Streams}

A potential for exposure to ${ }^{137} \mathrm{Cs}$ in Savannah River water remains as long as there is a potential for cesium resuspension from the SRS stream beds. Table 6.14 shows data for total estimated annual operational discharges to surface waters at the SRS from 1954 through 1990. On the basis of decay correction only, approximately $310 \mathrm{Ci}$ would remain from the approximately $570 \mathrm{Ci}$ discharged since 1954.

USDOE (1990), estimates that future operations of $K, L$, and $P$ reactors would discharge annual totals of $9.55 \times 10^{-2} \mathrm{Ci}$ of ${ }^{137} \mathrm{Cs}$. If it is conservatively assumed that five per cent of the total comes from K Reactor, future operations of only K Roactor will annually discharge $4.8 \times 10^{-3} \mathrm{Ci}$ to Pen branch.

Simulations, assuming either no operations or operations of $\mathrm{K}$ Reactor for the next ihree centuries, have been performed. These simulations show that, with or without operations, ${ }^{137} \mathrm{Cs}$ release from the SRS streams to the Savannah River at the previously estimated average rate of $0.45 \mathrm{Ci} / \mathrm{yr}$ (section 6.3.3), will last into the twenty-second century. There is a $95 \%$ probability that the SRS burden will be less than $0.45 \mathrm{Ci}$ either by about 2123 , if there are no reactor operations, or approximately one year later, if $\mathrm{K}$ Reactor is operated until that tirie. Radioactive decay is the major mode of loss of ${ }^{137} \mathrm{Cs}$ from the stream beds until the year 2081. From 2081 onward, the amount of ${ }^{137} \mathrm{Cs}$ lost by decay per year is less than the annual amount released from the SRS $(0.45 \mathrm{Ci} / \mathrm{yr})$ to the Savannah River. 
Table 6.14. Annual Discharges (Ci) of ${ }^{137} \mathrm{Cs}$ from SRS Operations to Surface Waters

\begin{tabular}{|c|c|}
\hline Year & $\begin{array}{c}\text { Discharge of }{ }^{137} \mathrm{Cs} \\
\text { from SRS Operations } \\
(\mathrm{Ci})^{\mathrm{a}}\end{array}$ \\
\hline 1954 & $2.5 \mathrm{E}-01$ \\
1955 & $6.7 \mathrm{E}-01$ \\
1956 & $2.0 \mathrm{E}+00$ \\
1957 & $4.9 \mathrm{E}+01$ \\
1958 & $3.9 \mathrm{E}+00$ \\
1959 & $7.5 \mathrm{E}+00$ \\
1960 & $2.8 \mathrm{E}+01$ \\
1961 & $2.0 \mathrm{E}+01$ \\
1962 & $3.1 \mathrm{E}+01$ \\
1963 & $9.9 \mathrm{E}+01$ \\
1964 & $1.0 \mathrm{E}+02$ \\
1965 & $3.1 \mathrm{E}+01$ \\
1966 & $3.7 \mathrm{E}+01$ \\
1967 & $7.8 \mathrm{E}+01$ \\
1968 & $4.3 \mathrm{E}+01$ \\
1969 & $1.8 \mathrm{E}+01$ \\
1970 & $1.1 \mathrm{E}+01$ \\
1971 & $2.6 \mathrm{E}+00$ \\
1972 & $1.2 \mathrm{E}+00$ \\
1973 & $7.4 \mathrm{E}-01$ \\
1974 & $1.1 \mathrm{E}+00$ \\
1975 & $6.9 \mathrm{E}-01$ \\
1976 & $2.3 \mathrm{E}-01$ \\
1977 & $4.6 \mathrm{E}-01$ \\
1978 & $1.9 \mathrm{E}-01$ \\
1979 & $1.8 \mathrm{E}-01$ \\
1980 & $1.4 \mathrm{E}-01$ \\
1981 & $1.3 \mathrm{E}-01$ \\
1982 & $1.4 \mathrm{E}-01$ \\
1983 & $1.4 \mathrm{E}-01$ \\
1984 & $2.3 \mathrm{E}-01$ \\
1985 & $8.0 \mathrm{E}-02$ \\
1986 & $8.4 \mathrm{E}-02$ \\
1987 & $3.3 \mathrm{E}-01$ \\
1988 & $4.9 \mathrm{E}-01$ \\
1989 & $2.1 \mathrm{E}-01$ \\
1990 & $4.8 \mathrm{E}-02$ \\
\hline
\end{tabular}

aFrom SRS data provided by David Hayes. 


\subsubsection{Sensitivity Analysis}

Ingestion of finfish provides the dominant exposure pathway for cancer mortality risk from ${ }^{137} \mathrm{Cs}$ released to the Savannah River. The ratios of average exposure from ingestion of fish (Table 6.10) to average exposure from drinking water (Table 6.8) are 18 for Beaufort-Jasper and 9 for Port Wentworth.

\subsubsection{Uncertainties}

The sensitivity analysis above indicates that ingestion of fish caught in the Savannah River is the predominant factor in estimating the exposures and risks. In addition to considerations of quantities of fish ingested, the major uncertainty is the concentration of ${ }^{137} \mathrm{Cs}$ in the fish (Hamby, 1991). In thisreport, it is assumed that the distribution of BCFs in fish at or near the level of the two receptor sites is the same as the distribution calculated for BCFs near the SRS. Therefore, two major interacting factors in the exposure estimates are quantities of fish ingested and [ ${ }^{137} \mathrm{Cs}$ ] in the sdible portion of the fish.

Another source of uncertainty, is the amount of drinking water that is ingested. This analysis used annual water intakes based upon 1978 data (Hamby, 1991, 1992) for the Southern United States. Calculations from a recent study (Ershow and Cantor, 1989) yielded an average intake rate in the South that was $130 \mathrm{~L}$ per year greater than our original estimate. A lognormal distribution (Roseberry and Burmaster, 1992) of the higher annual water intake yielded negligible increases of the average IR and the upper $95 \%$ confidence limit in our calculations for both major receptors (Table 6.15).

Table 6.15. Recalculateda Incremental Individual Cancer Risks (IR) from intakes of ${ }^{137} \mathrm{Cs}$ in Savannah River Water at the Beaufort-Jasper (BJ) and Port Wentworth (PW) Facilities and in Savannah River Fish.

\begin{tabular}{|ccc|}
\hline Average & $\frac{\text { IRB }}{\text { B }}$ & $\frac{\text { IRPW }}{2.3 \mathrm{E}-9}$ \\
SD & $2.0 \mathrm{E}-9$ & $4.1 \mathrm{E}-9$ \\
Upper $95 \%$ Confidence Limit & $3.9 \mathrm{E}-9$ & $8.1 \mathrm{E}-8$ \\
\hline
\end{tabular}

aBased upon a lognormal distribution of annual water ingestion rates (average, $470 \mathrm{~L} / \mathrm{yr}$; SD, 264 Lyr; range, 63-2710 L/yr) derived from Ershow and Cantor (1989)

\section{SUMMARY}

Cancer mortality risks were analyzed for projected public exposures to ${ }^{3} \mathrm{H}$ and ${ }^{137} \mathrm{Cs}$ released into the Savannah River from the Savannah River Site (SRS). Two receptor populations for the two radionuclides are supplied with water taken from the river approximately 80 miles downstream from the SRS by the Beaufort-Jasper Water Treatment Plant and the Port Wentworth Water Treatment Plant. The two facilities are expected to provide drinking water to domestic populations totalling 317,000 people by the year 2000 .

Tritium contributes approximately $99 \%$ of the radioactive releases (Ci) to the Savannah River from the SRS, primarily in the form of tritiated water. An empirical model was developed for tritium 
release to and transport in the Savannah River, based upon available data. The analysis predicts that the total quantity of $3 \mathrm{H}$ released to the river will vary annually until 2004 because of movement from waste storage and seepage basins into onsite surface waters by way of the ground water. The variation in movement is largely dependent on historic patterns of discharge to the basins. By the year 2004, groundwater movement of tritium from pre 1990 operations into surface waters is expected to reach negligible levels. Thereafter, annual discharges of tritium into surface waters are expected to remain similar to the discharge in 2004 , based upon the level of planned reactor operations.

The distribution of concentrations of $3 \mathrm{H}$ in the river $(\mathrm{pCi} / \mathrm{L}$ ) is highly dependent on annual water flow volume, as well as the quantities released from the SRS. The major exposure pathways for the two receptor populations are by ingestion of tap water, and inhalation of water vapor while bathing in the home. Other pathways result in exposures that are lower by at least one order of magnitude.

Risks from tritium exposure were calculated as incremental (additional) lifetime risks of cancer death per year of exposure, above the risks of cancer death from all other causes. For the maximal annual receptor exposures estimated from SRS releases to the Savannah River, the calculated incremental individual risks $\left(8 \times 10^{-7}\right.$; upper $95 \%$ confidence limit) in either receptor population are lower ihan the risks ( $4 \times 10^{-6}$; upper $95 \%$ confidence limit) for the current EPA Drinking Water Standard for tritium when both are run through the same analyses. On a population basis, no deaths are expected in either receptor population as a result of exposures to tritium released to the Savannah River from the SRS.

The chemical behavior of cesium is similar to the behavior of potassium. A major portion of the ${ }^{137}$ Cs released from SRS operations resides in the sediments of the Savannah River bed and the onsite tributaries. The analysis estimates that an average of less than $0.5 \mathrm{Ci}$ per year is released for circulation in the river as soluble and particulate cesium. In the presence or absence of further operations at the SRS, this level of release is estimated to be maintained into the first quarter of the twenty-second century.

The distribution of the concentration of ${ }^{137} \mathrm{Cs}$ in the river water is also highly dependent on annual water flow. The two major pathways for exposure in the two receptor populations are drinking water ingestion and finfish ingestion. The water purification plants remove an average of $39 \%$ of the ${ }^{137} \mathrm{Cs}$, based upon 1983-1986 data. On the other hand, finfish bioconcentrate ${ }^{137} \mathrm{Cs}$. Finfish in the Savannah River near the two receptors are assumed to have the same distribution of bioconcentration factors as fish in the vicinity of the SRS. The analysis estimates that exposure from finfish ingestion is, on average, 9 to 18 times greater than drinking water exposure. The upper $95 \%$ confidence limit for incremental individual lifetime risks from one year's exposure $10{ }^{137} \mathrm{Cs}$ is less than $10^{-8}$, in either of the two receptor populations. The same calculation for the EPA Drinking Water Standard yields a $7 \times 10^{-6}$ lifetime risk (upper $95 \%$ confidence limit). On a population basis, no deaths are expected in either receptor population as a result of exposures to ${ }^{137} \mathrm{Cs}$ released to the Savannah River from the SRS. 


\section{References}

Bennett, C.S., T.W. Cooney, K.H. Jones, and P.A. Conrads (1990), Water Resources Data, South Carolina: Water Year 1990, U.S. Geological Survey Water-data Report SC-90-1, Columbia, SC.

Bronaugh, R.L., R.F. Stewart and M. Simon (1986), Methods for in vitro percutaneous absorption studies VII. Use of excised human skin. J. Pharm. Sci. 75: 1094-1097.

Bruner, H.D. (1973), Distribution of tritium between the hydrosphere and invertebrates, pp. 303-313 in Tritium, A.A. Moghissi and M.W. Carter (eds.), Messenger Graphics, Phoenix, AZ.

Cohrssen, J.J., and V.T. Covello (1989), Risk Analysis: A Guide to Principles and Methods for Analyzing Health and Environmenial Risks. United States Council on Environmental Quality, Executive Office of the President.

CRC Handbook of Chemistry and Physics (1986), 67th edition, R.C. Weast (ed. ), p. F-45, CRC Press, Boca Raton, FI.

Cummins, C.L., D.K. Martin, and J.L. Todd (1990), Savannah River Site Environmental Report for $1989(U)$, Volumes 1 \& 2. WSRC-IM-90-60.

Cummins, C.L., D.K. Martin, and J.L. Todd (1991), Savannah River Site Environmental Report (U), Volumes 1 \& 2. WSRC-IM-91-28.

Davis, H.A., D.K. Martin, and J.L. Todd (1989), Savannah River Site Environmental Report for 1988 (U), Volumes 1 \& 2. WSRC-RP-89-59-1.

DHHS (1990), Vital Statistics of the United States, 1987. U.S. Department of Health and Human Services, Public Health Service, Hyattsville, Md.

Dragun, J. (1988), The Soil Chemistry of Hazardous Materials. Hazardous Materials Control Research Institute, Silver Spring, Maryland, $458 \mathrm{pp}$.

Droppo, J.G., Jr., J.W. Buck, D.L. Strenge and M.R. Siegel (1990). Analysis of Health Impact Inputs to the U.S. Department of Energy's Risk Information System. PNL-7432, Pacific Northwest Laboratory, Richland Washington.

Ershow, A.G., and K.P. Cantor (1989), Total Water and Tapwater Intake in the United States: Population Based Estimates of Quantiles and Sources, Life Sciences Research Office, Federation of American Societies for Experimental Biology, Bethesda, MD.

Ettenhuber, E. and W. Röhnsch (1975), Impact of nuclear releases into the aquatic environment. pp 473-482 in Proceedings of an International Symposium on Radiological Impacts of Releases from Nuclear Facilities into Aquatic Environments, International Atomic Energy Agency, Vienna.

Feinendegen, L.E. (1967), Tritium-Labeled Molecules in Biology and Medicine, Acad. Press, New York, NY. 
Hamby, D.M. (1991), Land and Water Use characteristics in the Vicinity of the Savannah River Site (U), WSRC-RP-91-17, Westinghouse Savannah River Company, Savannah River Site, Aiken, SC.

Hamby, D.M. (1992), Site-specific parameter values for the Nuclear Regulatory Commission's food pathway dose model. Health Phys. 62: 136-143.

Harrison, F.L., J.J. Koranda and J.S. Tucker (1973), Tritiation of Aquatic animals in an experimental marine pool, pgs 363-377 in Tritium, A.A. Moghissi and M.W. Carter (eds.), Messenger Graphics, Phoenix, AZ.

Holmes, W.N. and E.M. Donaldson (1969), The body compartments and the distribution of electrolytes, Chapter 1, pp. 1.90 in Fish Physiology, vol. 1, Excretion, Ionic Regulation and Metabolism, W.S. Hoar and D.J. Randall (eds.), Academic Press, New York, NY.

ICRP (1979), Radiation Protection: ICRP Publication 30, Supplement to Part 1, Limits for Intakes of Radionuclides by Workers-A Report of Committee 2 of the International Commission on Radiological Protection, Pergamon Press, New York, NY.

ICRP (1989), Radiation Protection: ICRP Publication 56, Part 1, Age Dependent Doses to Members of the Public from Intake of Radionuclides-A Report of a Task Group of Committee 2 of the International Commission on Radiological Protection, Pergamon Press, New York, NY.

ICRP (1991), Radiation Protection: ICRP Publication 60, 1990 Recommendations of the International Commission on Radiological Protection, Pergamon Press, New York, NY. Isherwood, D. (1979), Geoscience Data Base Handbook for Modeling a Nuclear Waste Repository. NUREG/CR-0912, Volume 1 (UCRL-52719).

Mallon, B., R.W. Bainer, B. Qualheim and J. lovenitti (1991), Investigations of tritiated water in the vadose zone from a leak in an underground tank. Abstracts with Programs.-Annual Meeting, San Diego, California, October 21-24, 1991, The Geological Society of America, Boulder, Co, pg A24 (abstr. \#25169).

Mckone, T.E. (1990), Dermal uptake of organic chemicals from a soil matrix. Risk Analysis 10: 407-419.

McKone, T.E. and J.I. Daniels (1991), Estimating human exposures through multiple pathways from air, water, and soil. Reg. Toxicol. Pharmacol. 13: 36-61.

McKone, T.E. and K.T. Bogen (1992), Uncertainties in health-risk assessment: An integrated case study based on tetrachloroethylene in California groundwater. Reg. Toxicol. Pharmacol. 15: 86103

Mikol, S.C., L.T. Burckhalter, J.L. Todd, and D.K. Martin (1988), Savannah River Plant Environmental Report: Annual Report for 1987. Volumes 1 \& 2. DPSPU-88-30-1.

Morgan, T.J., R.R. Landolt and J. Hamelink (1973), Behavior of tritium in fish following chronic exposure, pgs 378-381 in Tritium, A.A. Moghissi and M.W. Carter (eds.), Messenger Graphics, Phoenix, AZ. 
Morris, S.C. (1990), Baseline Risk Information for Formal Priority System Fiscal Year 1992 Interim System Application, Brookhaven National Laboratory, Upton, NY 11973.

Morris, S.C. and A.F. Meinhold (1988), Report of Technical Support for the Hezardous Waste Remedial Program on Health and Environmental Risks of Inactive Hazardous Waste Sites, BNL42339, Informal Report, Brookhaven National Laboratory, Upton, NY 11973.

Murphy, C.E., Jr., L.R. Bauer, D.W. Hayes, W.L. Marter, C.C. Zeigler, D.E. Stephenson, D.D. Hoel and D.M. Hamby (1991), Tritium in the Savannah River Site Environment (U), WSRC-RP-424-1, Revision 1, Westinghouse Savannah River Company, Savannah River Site, Aiken, SC 29808.

NCP (1990), National Oil and Hazardous Pollution Contigency Plan, 40 CFR 300.

NCRP (1977), Cesium-137 from the Environment to Man: Metabolism and Dose, NCRP Rep. No. 52, National Council on Radiation Protection and Measurements, Washington, DC.

NCRP (1979), Tritium in the Environment, NCRP Rep. No. 62, National Council on Radiation Protection and Measurements, Washington, DC.

NRC (1990), Health Effects of Exposure to Low Levels of lonizing Radiation: BEIR V, National Research Council, National Academy Press, Washington, DC.

Roseberry, A.M., and D.E. Burmaster (1992), Lognormal distributions for water intake by children and adults. Risk Analysis 12: 99-104.

Straume, T. (1991), Health Risks from Exposure to Tritium, Lawrence Livermore National Laboratory, Livermore, CA, UCRL-LR-105088.

Sun, L.C., J.H. Clinton, and C.B. Meinhold (1991), Whole Body Counting in The Marshall Islands, BNL-46439, Proceed. 37TH Annual Conference On Bioassay, Analytical and Environmental Radiochemistry, Ottawa, Ontario, Canada, October 7-11, 1991.

Till, J.E., and H.R. Meyer (1983), Radiological Assessment: A Textbook on Environmental Risk Analysis. NUREG/CR-3332, ORNL-5968. U.S. Nuclear Regulatory Commission, Washington, O.C.

U.S. DA (1983), Food Consumption: Households in the South, Seasons and Year 1977-1978, NFCS 1977-78 Report No. H-9, United States Department of Agriculture, August 1983.

U.S. NRC (1977), Regulatory Guide 1.109: Calculation of Annual Dose to Man from Routine Releases of Reactor Effluents for the Purposes of Evaluating Compliance with 10 CFR Part 50, Appendix I, Revision 1, United States Nuclear Regulatory Commission, October 1977.

USDOE (1988), Environmental Survey Preliminary Summary Report of the Defense Production Facilities. DOE/EH-0072. Environment, Safety, and Health. Office of Environmental Audit. U.S. Department of Energy, Washington, D.C.

USDOE (1990), Final Environmental Impact Statement:Continued Operation of K-, L-, and P. Reactors, Savannah River Site, Aiken, South Carolina, Volume 1. U.S. Department of Energy DOE/EIS-0147. 
USEPA (1977), National Interim Primary Drinking Water Regulations. EPA-570/9-76-003, United States Environmental Protection Agency, Washington, D.C.

USEPA (1989), Risk Assessment Guidance for Superfund. Volume I Human Health Evaluation Manual (Part A), Interim Final. EPA540/1-89/002, Office of Emergency and Remedial Response, United States Environmental Protection Agency, Washington, DC.

USEPA (1990), Exposure Factors Handbook. EPA600/8-043, Office of Health and Environmental Assessment, United States Environmental Protection Agency, Washington, DC.

USEPA (1991), 40 CFR Parts 141 and 142 National primary drinking water regulations; radionuclides; proposed rule, Federal Register Part II 56 (No. 138): 33050-33127.

Zeigler, C.C., E.M. Heath, L.B. Taus, and J.L. Todd (1987), Savannah River Plant Environmental Report: Annual Report for 1986, Volumes 1 \& 2. DPSPU-87-30-1. 


\section{APPENDIX 1 -- GROUND WATER CONTAMINATION IN THE A\&M AREA}

\section{$A$ and $M$ Areas}

The administration and manufacturing Areas ( $A$ and $M$ areas) are located in the northwest portion of the SRS (Figure A.1). A area includes research and administrative facilities. $M$ area produces nuclear fuels, targets and other reactor components (Cummins et al., 1991).

Figure A.1. Western Portion of the Savannah River Site; Showing the Location of the A and M Areas

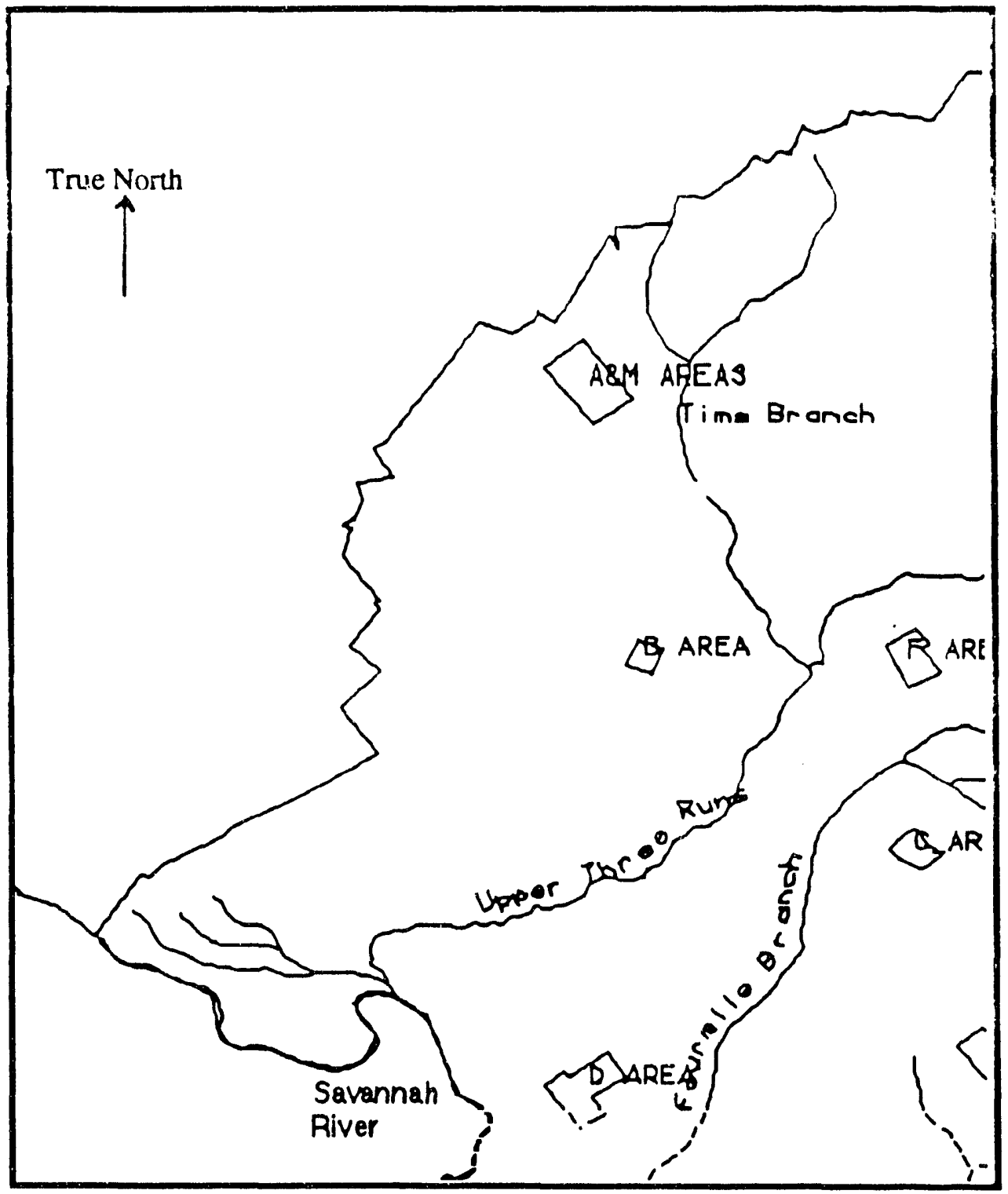

The $A$ and $M$ areas contain numerous sites where hazardous and toxic substances were discharged or spilled. $A$ and $M$ areas are on a water table mound with radial flow east toward Tims Branch, southwest toward the Savannah River, and north and west toward apparent drainage into lower topographic zones (Cummins et al., 1991). Most of the water-table water migrates downward into lower water bearing zones. 


\section{Groundwater Contamination}

Grourid water contamination has been detected in wells monitoring the $A$ and $M$ areas. The two areas are contiguous, and contaminant plumes overlap both areas. The $M$ area plume represents one of the largest known contaminant plumes on SRS. The primary contaminants exceeding drinking water standards are two chlorohydrocarbon degreasers, letrachloroethylene (PCE = perchloroethylene) and trichloroethylene (TCE), which are potentially carcinogenic.

The presence of these contaminants results from previous practices (considered acceptable at the time) of channeling waste materials from industrial processes directly to surface water runoff, and later to unlined seepage and storage basin systems. Starting in 1954, M Area effluent (including degreasers) was discharged through a sewer to Tims Branch, a tributary to Upper Three Runs Creek (Figure 3.1). In 1958, the M Area Settling Basin was constructed to retain effluent contaminants. Large quantities of the volatile organic degreasing solvents are believed to have evaporated prior to reaching the water table below the Settling Basin.

Inadvertent leaks from the conduits to the stream and the basins added to the seepage from the waste storage facilities (and overflows thereof) into the groundwater. To the East of the A\&M Areas. the intersection of the water table with Tims Branch restricts the downward migration of the organic solvents. A remediation program has been underway since 1983 to remove volatile organic contaminants using recovery wells and an air stripper. Pumping has markedly changed groundwater flow in the area. Maximum trichloroethylene and tetrachloroethylene concentrations measured in plume definition wells in 1990 were $83 \mathrm{mg} / \mathrm{l}$ and $114 \mathrm{mg} / \mathrm{l}$, respectively (Cummins et al., 1991).

\section{Groundwater Monitoring Program}

The Groundwater Monitoring Program at SRS is performed by several organizations within the Westinghouse Savannah River Company. The Groundwater Monitoring Group of the Environmental Monitoring Section within the Environmental Health Protection Department (EHP), the Environmental Science Section of the Savannah River Technology Center, and the operating departments of the SRS are responsible for components of the monitoring program. In addition to the monitoring performed by the EHP, the SRS Raw Materials Engineering and Technology Department monitored for volatile organics in the $A$ and $M$ Areas in the first quarter of 1988.

Groundwater samples from wells are collected for analyses of nonradioactive constituents either annually, semiannually or quarterly. The samples are shipped to contractor laboratories, certified by the South Carolina Department of Health and Environmental Control, to conduct the required analyses. The sampling schedule is revised annually on the basis of regulatory requirements and historical data on groundwater contamination. Analytical results of groundwater monitoring from SRS wells are compared with federal primary drinking water standards (40 CFR 141-142). For the pollutants of interest, TCE and PCE, the standards are $0.005 \mathrm{mg} / \mathrm{L}$.

Bizside the waste-site groundwater monitoring in $A$ and $M$ Areas, groundwater is also monitored over a 5-square-mile-area for volatile organics, by approximately 280 plume definition wells, including wells not under the waste-site monitoring program. 


\section{Potential for Offsite Exposures}

The assessment performed for the USDOE Environmental Survey, using MEPAS, assumed that contaminants in ground water in the $A$ and $M$ areas could impact offsite receptors west of the Savannah River Site. The hydrology of the $A$ and $M$ areas allows a vertical gradient flow of pollutants down into the Tuscaloosa (= Cretaceous) formation, the major aquifer that could potentially transfer these pollutants to offsite receptors. Five wells, serving two small communities, are within five miles of Areas $A$ and $M$. The current state of knowledge based on field data and modeling studies suggests that such offsite transport of contaminants is unlikely. The following sections describe and critically review the most recent modeling effort upon which this conclusion is based.

\section{Groundwater Flow Model}

A groundwater model of the Savannah River Plant AM Area has been used as a tool to study. define, and assess ground-water flow in and around this documented area of chlorinated hydrocarbon contamination. The modeling effort has gone through an evolutionary process whereby each successive endeavor has built upon the last. The most recent effort to further develop the groundwater model was by Schreuder \& Davis, Inc. (Beaudoin et al., 1991), hereatter referred to as SDI. The purpose of this model was to provide groundwater elevation data that could be used to evaluate the effectiveness of the proposed groundwater remediation pumpage plan. The SDI draft report (Beaudoin et al., 1991) documents the development, construction, and calibration of a coarse-grid model of the area. The code used in this analysis was a modified version of MODFLOW (McDonald and Harbaugh 1988). This coarse-grid model will subsequently be used to simulate groundwater flow areas of interest where a finer grid system will be included to provide more detailed water-level elevations. These detailed model predicted ground-water level elevations will be used for a capture zone analysis of contaminated ground water in the various aquifers. The objectives of this project were to update existing modeling efforts and update the calibration and validation of the coarse-grid model.

Initial modeling efforts of the AVM Area assisted in the location of 11 shallow recovery wells that were pumping at a total combined rate of 410 gallons per minute (gpm). Groundwater contamination, however, had also been detected in the underlying Tuscaloosa formation, which is an extensive regional aquifer in which plant production wells were completed. In an effort to halt further downward migration of chlorinated hydrocarbon contamination into the Upper Tuscaloosa aquifer, major deep groundwater production was shifted to another area farther away from the operational area. However, existing production wells were kept operating at a lesser pumping rate to act as contaminant capture wells to intercept contamination that had reached the Upper Tuscaloosa aquifer.

The A/M Area encompasises a manufacturing and processing area, a previous waste-effluent disposal basin with an overflow to a natural depression (Lost Lake), and several surface water features. The total modeled area ( 31.4 square miles) is a rectangle 25,000 feet from east to west and 35,000 feet from north to south. It covers an area much larger than just the AM Facility described above. The model has a regular spaced grid with 1,000 by 1,000 foot grid blocks. The model was vertically allocated into four layers. The layers in descending order are: the water table, Upper Congaree, Lower Congaree, and Black Creek (Upper Tuscaloosa). 
The final evaluation of potential off-site contaminant migration in the deep aquifer will be based on simulated capture zone analysis. These efforts have yet to be documented. An attempt to draw conclusions regarding plume capture based solely on the existing calibrated flow model simulation may be misleading. Although the model indicates ground-water flow conditions under a given stress, future remedial actions may define a different stress that will be placed on th. $\rightarrow$ ground-water system. These stresses may or may not alter the potential for off-site contaminant migration in the Upper Tuscaloosa.

The model documented by SDI (Beaudoin at al., 1991) supports the position that, given the current level of knowledge and understanding of the ground water flow in the A\&M area, the potential for offsite transport of water (and contaminants) is small. The following sections review the model documented in Beaudoin et al., 1991.

\section{Model Review}

The model construction by SDI was designed to evaluate the effectiveness of various proposed recovery-well pumping scenarios to capture contaminated ground water in the AM area within 30 years. For this purpose, the model did not need to include distant portions of the SRS including the Savannah River. Presumably the boundaries of the model grid were placed far enough from potential pumping locations such that cones of depression would not intersect the boundaries.

The model could, however, be used indirectly to determine a portion of discharge to the Savannah River by calculating the amount of discharge to Tim's Branch and Upper Three Runs Cieek from the water table and Congaree aquifers. This amount could be assumed to discharge to the river through surface flow.

In keeping with the stated model purpose, all but one of the data points are clustered in the immediate AM area that encompasses the northeast quadrant of the model grid. One data point is located in the southern one-half of the grid and this cluster of wells has screens located in each of the modeled aquifers. Water-level data are, therefore, concentrated in the immediate AM area near the northeast model boundaries. Therefore, water- level contours are more accurate in the northeast than elsewhere in the modeled area. The water-level contours in the upper aquifers are likely to be more accurate than those in lower aquifers because the surface features such as streams and wetlands can be used as additional data points to estimate the elevation of the water table. This procedure was apparently followed because the contours can be seen to follow the surface features. Additional evidence that this approach was taken is that the surface water features were modeled as head dependent leakage boundaries.

The boundary conditions of the model in the Upper and Lower Congaree are not realistic, given the conceptual understanding of the flow system. Therefore, the model should not be used to predict contaminant movement beyond the immediate A\&M area. To simulate ground-water flow out of the Upper Congaree, constant head nodes are used as the northeast boundary conditions, and head dependent discharge nodes are used to simulate wetlands and streams in the southwest. Constant head nodes along the southeast boundary apparently simulate horizontal flow into the Upper Congaree. The observed water-level elevations used during model calibration indicate flow from the southeast and northeast to the south and west. The consequence is that all water entering the Upper Congaree (through recharge, leakance from above and below, and horizontal flow) is constrained to exit by way of the surface water and to the northeast. This contradicts the conceptual model where a horizontal flow component should occur towards the southwest out of the model grid 
and it contradicts the observed water-level elevations. Therefore, the model may not be used to simulate flow towards the Savannah River.

In the Lower Congaree, constant head nodes are used in the southeast corner to simulate water flowing into the Lower Congaree and along the northern boundary to simulate flow out of the Lower Congaree. These conditions contradict the observed water-level elevations and the conceptual model where flow should occur from the northeast to the southwest. The remainder of the horizontal boundaries for this layer are defined as no-flow boundaries. Because of extensive use of no-flow boundaries in the southwest, all water entering the Lower Congaree is constrained to exit through the Ellenton (downward) or into the Upper Congaree and then to surface waters. Flow into the Upper Congaree is facilitated because the aquitard between Upper and Lower Congaree is removed in the southeast portion of the model grid. There is not a component of flow to the southeast toward the Savannah River. Therefore, the model may not be used to simulate potential migration of contaminants beyond the model grid toward the river.

The Black Creek aquifer boundary conditions conform to the conceptual model and allow regional flow from the northeast to the southwest. However, the model in its present state could not be used to determine whether the Black Creek aquifer discharges to the Savannah River because the hydrogeology near the river has not been determined. Water-level data from the various aquifers needs to be collected to determined if all or some portion of the Black Creek flow discharges to the Savannah River.

In a discussion of the calibration of the model, the SDI report contradicts itself by stating that the northeast constant head nodes in the Upper and Lower Congaree aquifers provide for flow into the model (Page 24). Given that this is the correct formulation, the model no longer contradicts the observed water-level elevations. However, all water in the Upper and Lower Congaree aquifers are constrained to exit into the surface water or through the Ellenton formation into the Black Creek aquifer. This remains a contradiction of the conceptual model because lateral migration in the Upper and Lower Congaree aquifers continues to be constrained. Therefore, it may not be used to predict ground-water flow beyond the model boundaries.

In general, the following conclusions may be drawn:

1...While the hydrogeologic system at the SRS is relatively well understood and while it is probable that the Savannah River is the regional discharge area for most of the SRS including the AM area, the model prepared by SDI does not include the river and, therefore, may be used to determine the fate of contaminants that may approach the discharge area. The model grid ends approximately three miles northeast from the river and, therefore, it cannot be determined whether contaminants in the Black Creek aquifer (the lowermost) eventually discharge to the Savannah River.

2. ..Hydrogeologic data used to construct the model are clustered around the immediate $A / M$ area. Information (e.g., lithology and water-table elevations) is not available for approximately threefourths of the 35 square mile area that was modeled. Under such circumstances, results away from the model's control points should be regarded only as approximate.

3. ..The boundary conditions, in model Layers 2 and 3 (Upper and Lower Congaree), severely constrain the horizontal movement of the water beyond the modeled area. The horizontal boundary, including the entire western boundary and southwestern corner has been represented as a no-flow condition, thereby directing all aquifer discharge in the vertical direction to surface discharge and through the Ellenton confining unit. Given the model representation of the flow 
system, horizontal flow beyond the model boundary is not possible in the Upper and Lower Congaree. Therefore, the assessment of potential horizontal contaminant migration in these units. from a regional perspective, is not possible.

The conceptual understanding and numerical representation of the ground-water flow system as developed and constructed by SDI, are such, that ground-water (both actual and simulated) may discharge from the modeled area in several ways. If regional data from areas outside (southeast and southwest) of the modeled area verify that the interpretation of the system and the simulated boundary conditions are reasonable, the following conclusion may be drawn. The model generated water balances shows that 79 percent of ground-water flowing out of the model area occurs as discharge to surface water. Another 7 percent flows out by way of groundwater pumpage. The remaining 14 percent represents ground-water flowing out of the model through other boundaries. Approximately two-thirds of that remaining 14 percent occurs as regional groundwater flow in the Black Creek aquifer. Only 4 to 5 percent of the total amount of groundwater discharge to boundaries occurs in the water table and Upper and Lower Congaree aquifers, in this model. Although this model is not a solute transport model, the water budget infers that the potential for contaminated ground water (as mapped by SDI) to flow out from the modeled area is small as compared to discharge to remedial wells within the plume and surface water discharge.

\section{Conclusions}

Additional studies are ongoing in the A\&M area. The current state of knowledge suggests that offsite transport of organic contaminants in ground water from the A\&M Area are unlikely.

\section{REFERENCES}

Beaudin, C.M., P.J. Schreuder, and J.S. Haselow (1991), Draft: A Ground Water Flow Model for the AMM Area of the SRS (U), WSRC-RP-91-0585. Westinghouse Savannah River Company, Savannah River Laboratory, Savannah River Site, Aiken, SC.

Cummins, C.L., D.K. Martin and J.L. Todd (1991), Savannah River Site Environmental Monitoring Report for 1990 (U), Volumes 1 \& 2. WSRC-IM-91-28.

McDonald, M.G., and A.W. Harbaugh, (1988), A Modular Three-Dimensional Finite-Difference Ground-Water Flow Model. United States Geological Survey, Techniques of Water Resiurces Investigations, Book 6, Chapter A1. 

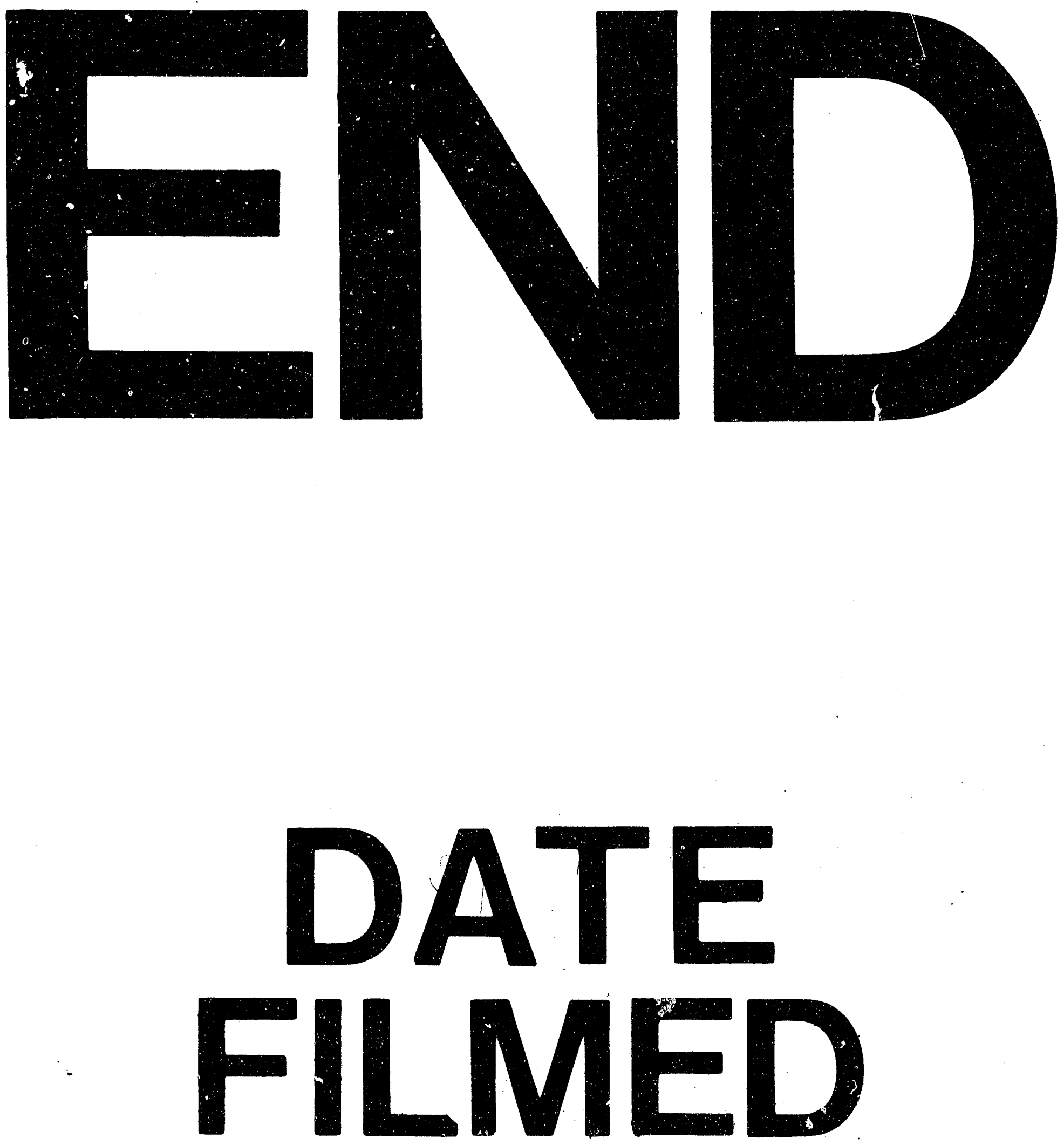

1

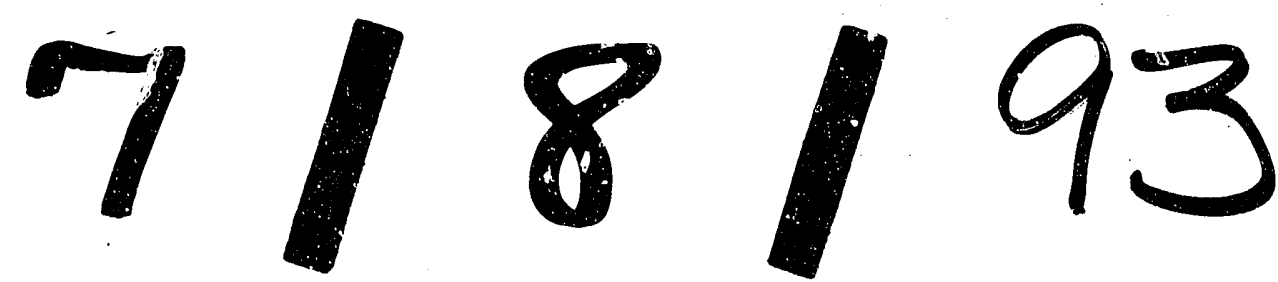


